DEPARTMENT OF THE INTERIOR

UNITED STATES GEOLOGICAL SURVEY

GHARLES D. WALCOT'T, DIREGTOR

\title{
FLUCTUATIONS OF THE WATER LEVEL IN WELLS, WITH SPECIAL REFERENCE TO LONG ISLAND, NEW YORK
}

\section{A. C. VEATCH}

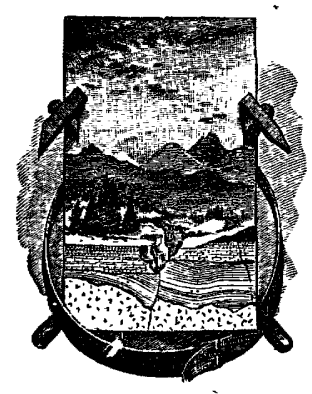

WASHINGTON

GOVERNMENT PRINTING OFFICE 



\section{ONTENTS.}

Introduction and summary $\quad$ Page.

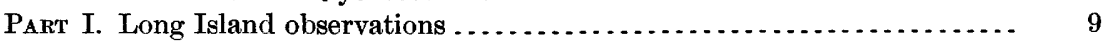

Introductory outline of hydrologic conditions................... 9

Observations of the United States Geological Survey . . . . . . . . . . . . . 10

Observations with direct-reading gages...................... 10

At Huntington, N. Y . . . . . . . . . . . . . . . . . . . . . . . 10

At Oyster Bay, N. Y .................................. 13

Observations with self-recording gages.................... 17

Instruments used . . . ................................. 17

At Queens County Water Company pumping station near Hewlett, N. Y . . . . . . . . . . . .

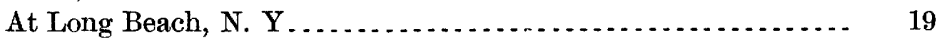

Near Millburn, N. Y ...................................... 22

At Lynbrook, N. Y . . . . . . . . . . .

At Douglaston, N. Y . . . . . . . . . . . . . .

Observations of the New York City commission on additional water supp ${ }^{1} y-\quad 27$

Part II. General discussion of the fluctuations of water in wells........... 28

Classification of causes .................................... 28

Fluctuations produced by natural causes....................... 29

Rainfall and evaporation ....................................... 29

Regular annual fluctuations ........................... 29

General character and cause ........................ 29

Effect of depth of soil above the zone of complete saturation on time of occurrence of yearly maximum and minimum.. 34

Irregular secular fluctuations .......................... 37

Amount of annual and secular fluctuation ................. 38

Fluctuations due to single showers....................... 42

By transmitted pressure without any increase in the ground water....................................... 42

By the actual addition of water to the ground water through percolation ................................... 44

Percentage of rainfall contributed to the ground water ......... 44

Methods of estimation ............................ 44

By lysimeters ...................................... 44

By stream discharge......................... 49

- By changes in level of ground-water table........... $\quad 50$

References relating to well fluctuations due to rainfall......... 51

Fluctuations due to barometric changes ...................... 52

Character and cause ................................ 52

References relating to well fluctuations due to barometric changes. $\quad 53$

Fluctuations due to temperature changes.................... 54

Observations at Madison, Wis.; fluctuations varying directly with the temperature.................................... 
Part II. General discussion of the fluctuations of water in wells-Cont'd.

Fluctuations produced by natural causes-Continued.

Fluctuations due to temperature changes-Continued.

Observations at Lynbrook, N. Y.; fluctuations inversely related to

the temperature....................................

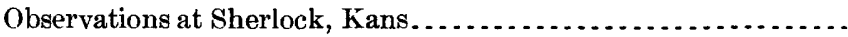

Diurnal fluctuations of Cache la Poudre River, Colorado .........

References relating to fluctuations produced by temperature

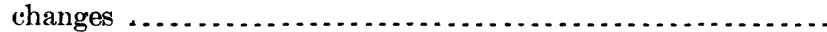

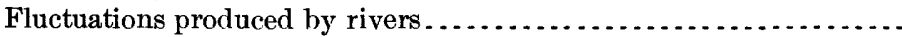

By change in rate of ground-water discharge .................

By irregular infiltration from rivers with normally impervious beds

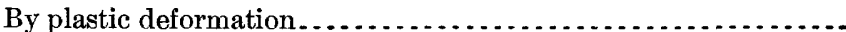

References relating to fluctuations produced by rivers...........

Fluctuations produced by changes in lake levels....................

Fluctuations produced by changes in the ocean level-tidal wells....

By changes in rate of outflow of ground water.................

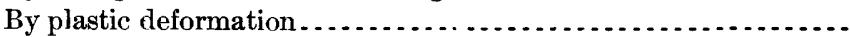

References relating to tidal fluctuations in wells ...............

Possibility of tides in the ground water produced by direct solar and

lunar attraction

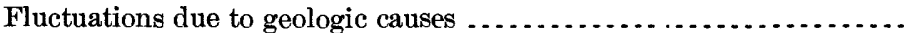

Fluctuations produced by human agencies. . . . . . . . . . . . . . . . . . . . .

Effect of settlement, deforestation, and cultivation .................

Effect of irrigation . . . . . . . . . . . . .

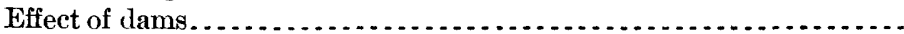

Effect of underground water-supply developments.................

Subsurface dams. . . . . . . . . . . .

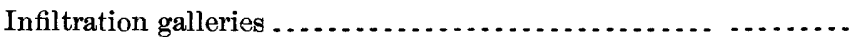

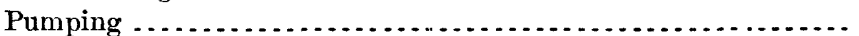

Artesian-well developments ..............................

Effect of large cities on the ground-water level. . ...................

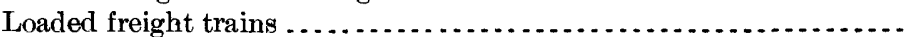

Fluctuations due to indeterminate causes........................

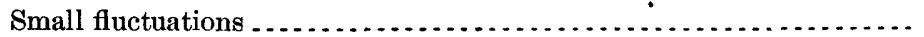

Fluctuations at Millburn, N. Y . . . . . . . . . . . . . . . . . . . . .

Fluctuations at Urisino Station, New South Wales...............

\section{ILLUSTRATIONS.}

PuAte I. Sketch map of western Long Island, New York, showirg localities discussed

II. Map of a portion of southern Long Island, New York, showing location of Hewlett, Long Beach, Millburn, and Lynbrook wells.....

III. Partial record of fluctuations of water level in a 181-foot well near Hewlett, N. Y 
Plate V. Partial record of fluctuations of water level in a 289-foot well næar

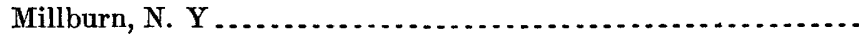

VI. Partial record of fluctuations of water level in wells at Lynbrosk,

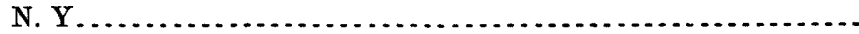

VII. Sketch map showing location and topographic surroundings of walls of the Citizens' Water Supply Company near Douglaston, N. Y...

VIII. Partial record of fluctuations of water level in wells near Douglaston,

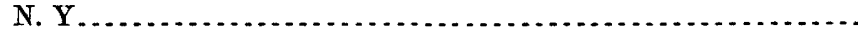

IX. Fluctuations of water level in wells near Wiener Neustadt, Austria.

FIG. 1. Diagrammatic cross section of Long Island, showing principal tonographic and geologic factors influencing the underground water csn-

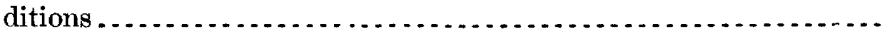

2. Sketch map showing location of well of Huntington Light and Pover Company at Huntington Harbor, N. Y ........................

3. Detail of well and tide curves at Huntington Harbor, N. Y., showing lag between well and tide..............................

4. Sketch map showing location of wells observed at Oyster Bay, N. Y..

5. Sketch map showing topographic surroundings of wells shown in fig. 4 and location of sections shown in figs. 6 and $7 \ldots \ldots \ldots \ldots . . . . .$.

6. Section at Oyster Bay, N. Y., along line B-B, fig. 5, showing geologic relations of wells observed

Page.

7. Section at Oyster Bay, N. Y., along line A-A, fig. 5, showing geologic relation of the artesian wells at Oyster Bay and on Center Island ..

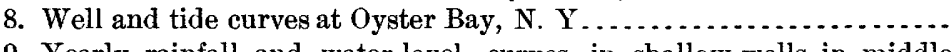

9. Yearly rainfall and water-level curves in shallow wells in midfle

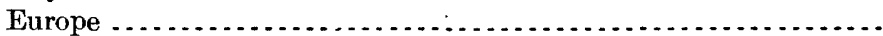

10. Yearly rainfall and water-level curves in shallow wells in the United States.

11. Mean annual ground-water curve at Bryn Mawr, Pa., and rainfall $\varepsilon$ nd temperature curves at Philadelphia, $\mathbf{P a}$.....................

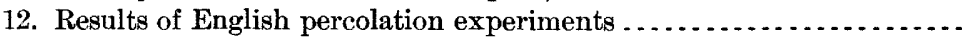

13. Fluctuations of water level in wells on Long Island, N. Y., from observations of New York City commission on additional water supply..

14. Residual-mass curves of rainfall for Long Island, N. Y., Newark, N. J., and Philadelphia, $\mathrm{Pa}$

15. Annual and secular changes of the ground-water level and fluctuations due to single showers in a shallow well at Millburn, N. Y ........

16. Fluctuations of water level in a well at Madison, Wis., showing nontransmission of diurnal fluctuations produced by changes in capillary attraction.

17. Diagram showing production of fluctuations of ground-water level by

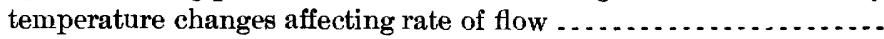





\section{FLUCTUATIONS OF THE WATER LEVEL IN W'ELLS, WITH SPECIAL REFERENCE TO LONG ISLAND. NEW YORK.}

By A. C. V̈eatch.

\section{INTRODUCTION AND SUMMARY.}

In connection with the investigation of the geology of Long Island by the United States Geological Survey in the summer of 1903 , a few observations were male on the fluctuation of the water level in wells, both with direct-reading and self-recording gages. In the consideration of these data, as well as those collected at the same time by the New York City commission on additional water supply, it has seemed desirable to enter into a general discussion of the fluctuation of water in wells.

Some of the results of this study may be briefly summarized as follows:

1. The most important and characteristic of the natural ground-water fluctuations is the regular annual period. This is a relatively uniform curve, with a single maximum and minimum, on which the fluctuations of shorter periods, as a rule, form but minor irregularities. This curve does not generally resemble the rainfall curve. Were the rainfall uniform throughout the year, the ground water would still show a regular yearly period and the maximum would occur early in the year in the North Temperate Zone. The effect of irregularities in the rainfall is to move the time of occurrence of this maximum either forward or back.

2. The water from single showers is generally delivered gradually to the groundwater table, and even where noticeable fluctuations are produced, these do not commonly make important irregularities in the regular annual ground-water curve.

3. Single showers may, by transmitted pressure through the soil air, produce instantaneous and noticeable rises in the water in wells and notably increase tl 9 stream discharge without contributing either to the ground water or directly to tre surface flow.

4. The amount contributed to the ground water can not be satisfactorily estimated by the rise and fall of the water in wells, because the same amount of rainfall under the same geologic and climatic conditions, in beds of the same porosity, will produce fluctuations of very different values. Near the ground-water outlet the total yearly range may be but a few inches, while near the ground-water divide it may be 50 or 100 feet. When an attempt is made to calculate the amount of water received from single rains, the results are not reliable, because in the cases which are usually taken, such as sharp, quick rises, it is impossible to tell how much of the rise is due to transmitted pressure and how much to direct infiltration.

5. Because of the increase in stream flow due (1) to transmitted pressure from rains, (2) to changes in barometric pressure, and (3) to increase in area $o^{f}$ groundwater discharge, with the elevation of the ground-water table, it is not possible to 
correctly separate the quantity of water in the stream discharge contributed by spring flow from that contributed by direct surface run-off. There are many reasons for believing that in humid regions "flood flows" contain large persentages of ground water.

6. Tidal fluctuations in wells are very often produced by a plastic deformation due to the loading of the tides, and the occurrence of such fluctuatiors in wells does not in itself indicate a connection between the water-bearing strata and the sea.

7. Temperature changes may produce marked fluctuations ( 1 ) by changes in capillary attraction-such fluctuations are perceptible only at the surface of the zone of complete saturation, are not transmitted to deeper levels, and vary directly with the temperature; (2) by changes in viscosity or rate of flow-fluctuations due to this cause vary inversely with the temperature, and show in deep walls by transmitted pressure. 


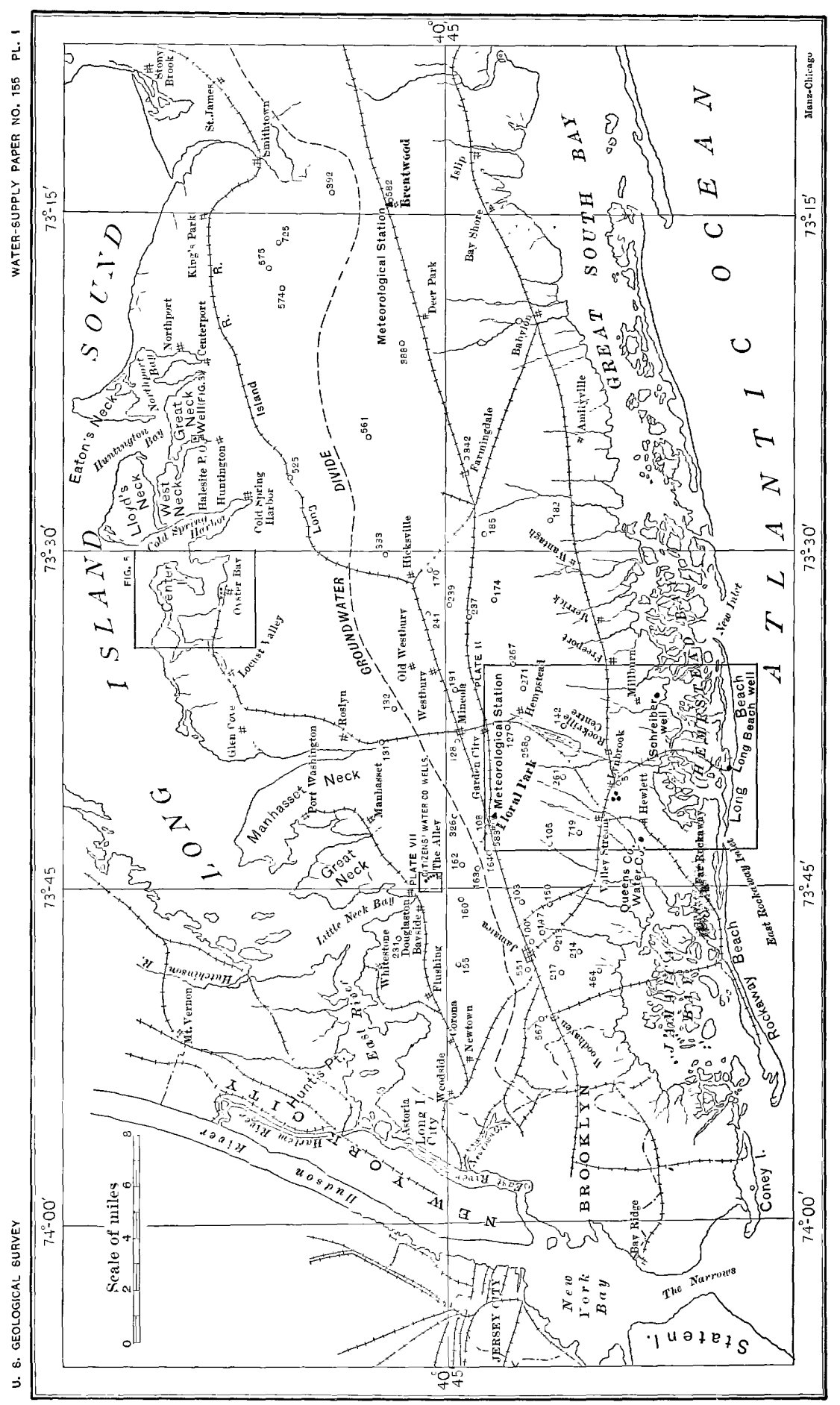

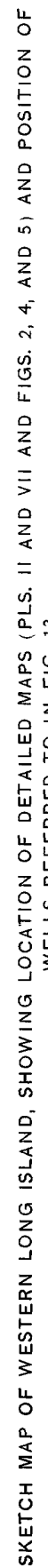




\section{PART I.}

\section{LONG ISLAND OBSERVATIONS.}

\section{INTRODUCTORY OUTLINE OF THE HYDROLOGIC CONDITIONS.}

The conditions on Long Island, New York, are particularly favorable for the study of the fluctuations of water in wells. The geologic and topographic cond tions are such that it may be affirmed that the underground water is derived wholly from the rain which falls on the surface of the island, and the problems involved are, therefore, not unduly complicated, as they are in many regions, by the possibility of the influx of water from other areas. In addition to this comparatively complete ground-water isolation, the island is of such a size-120 miles long and 20 miles wide-that ground-water phenomena can attain a relatively complete development, and the geologic structure of the water-bearing beds, while not complicated, is sufficiently varied to produce several differing conditions.

Topographically the western part of Long Island-the portion involved directly in this papermay be said to consist of a single range of rolling hills, usually 150 to 250 feet high, though in one place attaining an elevation of over 400 feet. This hill range descends somewhat abruptly to the north shore, where it is cut by several reentrant bays occupying old valleys. On the south side is a very flat gravel plain, sloping gently to the ocean, along which a series of barrier beaches inclosing long marshes has been developed. To the east the hill range divides and produces two hilly peninsulas, each with a single ridge on the northern side.

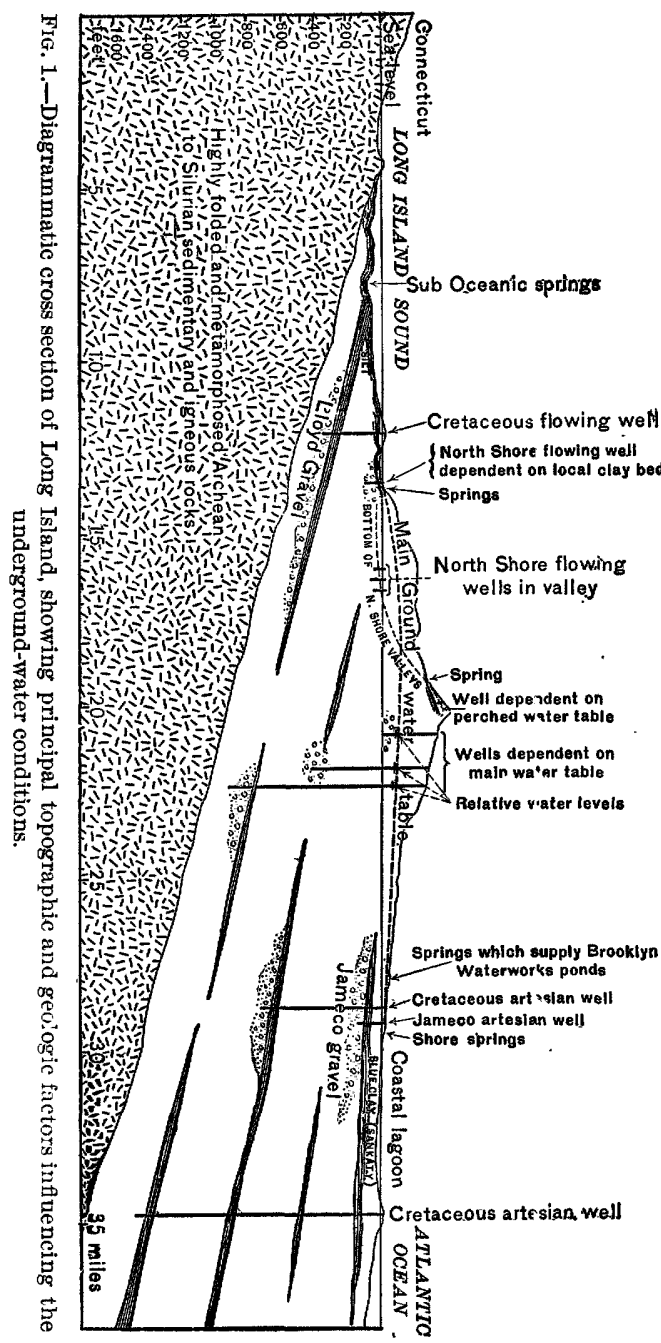

Geologically the island may be regarded as a series of relatively porous gravel and sand beds, containing irregular and discontinuous clay masses, the whcle limited 
below by the peneplained surface of a mass of highly disturbed an a metamorphosed Paleozoic and pre-Paleozoic rocks, which have little water value except as a more or less complete barrier to down ward percolation (fig. 1). While these unconsolidated beds represent, in the geologic time scale, several of the divisions of the Upper Cretaceous and as many as five Pleistocene or glacial stages, and as a whole are stratified deposits dipping at very low angles south and southeastward, they are, under the island, essentially continuous from a water standpoint, and the rain fallin $x$ on the surface is relatively free to pass to any part of the mass. The Pleistocene beds which form the surface are, however, as a rule, coarse and more porous than the underlying Cretaceous and tend to increase the absorbing power of the island. As a result, the percentage of rainfall which passes into the streams without first going through the ground is extremely small. $a$ This percolating water has entirely sa.turated the porous strata above the bed rock, except a limited portion at the surface, and has driven out the salt water which filled these beds when they were first denosited and which reoccupied them, at least in part, during the several submerger ès to which this region has been subjected. The surface of this zone of complete saturation, or the main ground-water table, is coincident with the sea level at the sl res and becomes more and more elevated in passing inland, though the rate of increase of elevation is less than that of the surface, of which it is but a subdued reflection (fig. 1). $b$

This slope of the ground-water table permits the development cf artesian wells at many points on the coast, at elevations which are commonly less than 10 feet above high tide. The head is, in all cases, due to the greater height of the ground water in the adjacent hill mass. In order that such a differential head may be developed, it is merely necessary that the water-bearing bed in question be coarser than the overlying beds. A clay or other impervious cover is not essential and, indeed, is often absent.

\section{OBSERVATIONS OF THE UNITED STATES GEOLOGICAL SURVEY.}

Observations on the fluctuations of the water level in wells were made by the Geological Survey near Huntington, Oyster Bay, Valley Stream, Millburn, Long Beach, and Donglaston, all villages on Long Island west of longitude $73^{\circ} \mathrm{W}$., and between latitudes $40^{\circ} 35^{\prime}$ and $40^{\circ} 55^{\prime} \mathrm{N}$. (Pl. I.)

\section{OBSERVATIONS WITH DIRECT-READING GAGES.}

\section{OBSERVATIONS AT HUNTINGTON, N. Y.}

The Huntington observations, from which the other Survey observations developed, were undertaken to test the common report that the discharge of nost of the artesian wells along the northern shore of Long Island fluctuated with the tide; in some cases the flow ranging from 0 at low tide to over 100 gallons per minute at high tide. Nearly all of these wells were being pumped, or were utilized to run rams, but permission was obtained to gage a newly completed well belonging to the Huntington Light and Power Company, at Huntington Harbor, until it should be connected with the pumps-a period of three or four days.

A direct-reading float gage of simple type was quickly constructed by Baker \& Fox, Brooklyn, N. Y. This consisted of a 2-inch cylinder of brass car'ying a $\frac{1}{4}$-inch aluminum rod 6 feet long and graduated to hundredths of a foot, with the zero point just

a Spear (Rept. New York City Commission on Additional Water Supply, 1904, p. 829) has estimated that 43 per cent of the total stream flow (or 14 per cent of the rainfall) can be considered as flood tlow or as not having passed through the ground. He bases this judgment on the relative heights of the stream and ground-water levels near the south shore, where, as explained on rage 51, a correct judgment can not be formed. The average flood flow is believed to be much less than 5 per cent of the precipitation.

$b$ For details of the slope of the ground-water table see Prof. Paper U. S. Geol. Survey No. 44, 1906, Pls. XI, XII. 
above the cylinder. For convenience in carrying, as well as to avoid the use of so long a rod except where absolutely necessary, the rod was divided into th ree parts and jointed. The cylinder was so constructed that it would just carry the total length of 6 feet, and when used with only 2 or 4 feet of rod, weights, balancing tha effect of the part removed, were added to the bottom of the cylinder.

Some trouble was experienced by the float tending to approach the side of the well and develop a thin capillary film between it and the pipe, which decreasec the sensitiveness of the gage. It is suggested that when direct-reading floats are used in wells of small diameter they be kept away from the walls of the well by means of

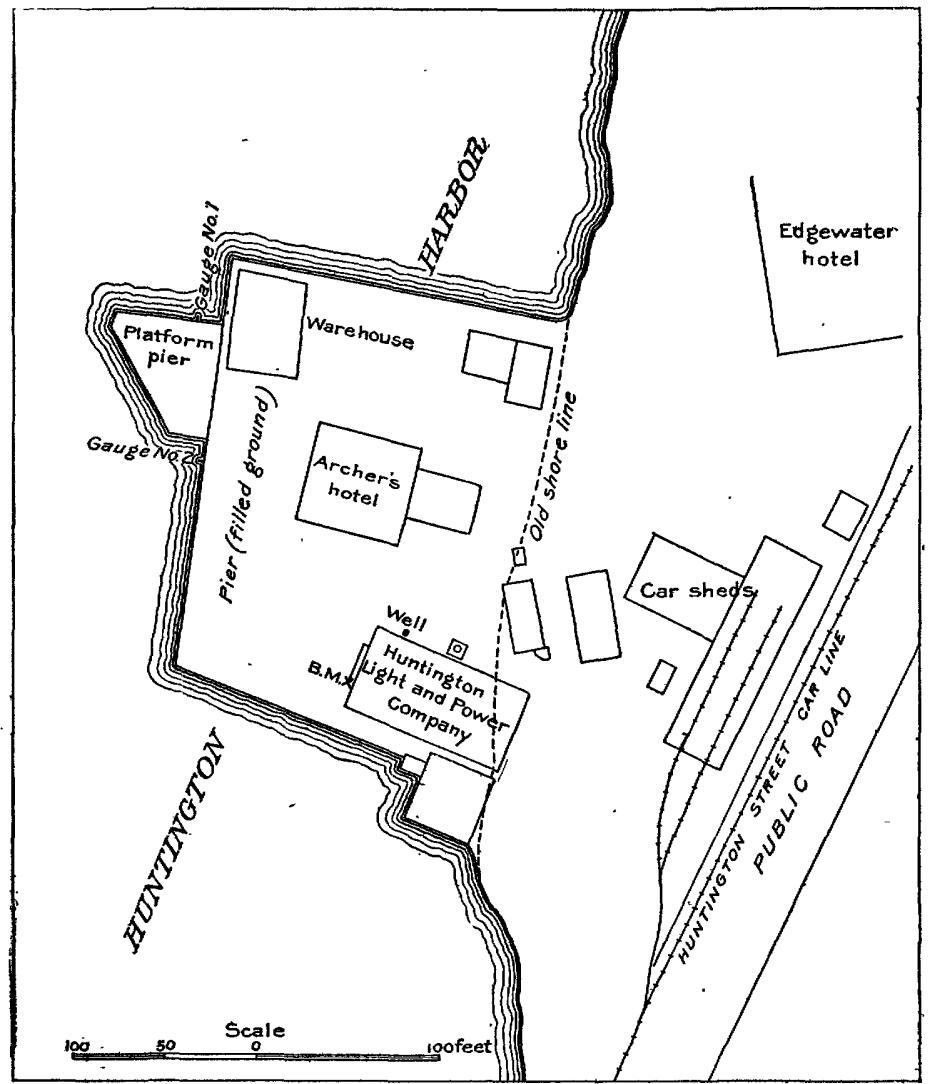

FIG. 2.-Sketch map showing location of well of Huntington Light and Power Company at Huntington Harbor, N, Y.

slightly arched wires, as in the float devised by Professor King for the self-recording gages used in the Madison experiments and later on Long Island.

The well of the Huntington Light and Power Company is situated on a dock at Huntington Harbor, near Halesite post-office (Pl. I, fig. 2.) The natural level of the surface at the point where the well is sunk is between high-and low-tide mark, but the ground has been built up by filling about 5 feet higher. The well is 75 feet deep and 4 inches in diameter, and the water rises in the pipe from 1 to 3 feet above the surface of the made ground. The well was piped above the limit of flow, so that all the fluctuations could be measured directly, rather than inferred from variations in the rate of discharge. 
The geologic section reported by the driller, Mr. H. J. Dubois, is as follows:

Section of well of Huntington Light and Power Company at Huntington Harbor, Halesite, N. Y.

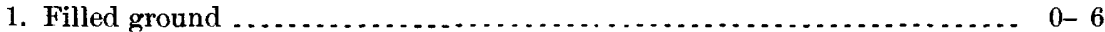

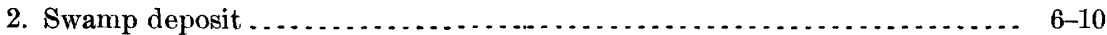

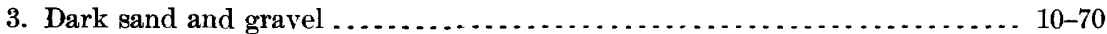

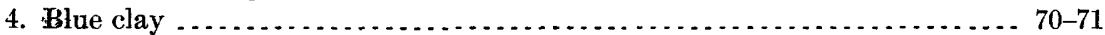

5. Light-yellow gravel containing artesian fresh water $\ldots \ldots \ldots \ldots \ldots \ldots \ldots \ldots \ldots \ldots \ldots$

The artesian flow is due to the height of the ground water in the steep hill just east of the well, the head being transmitted through the coarse bads encountered in the bottom of the well. Water escapes in many springs along the beach, but the movement through the lower gravels is freer and a differential head is produced,

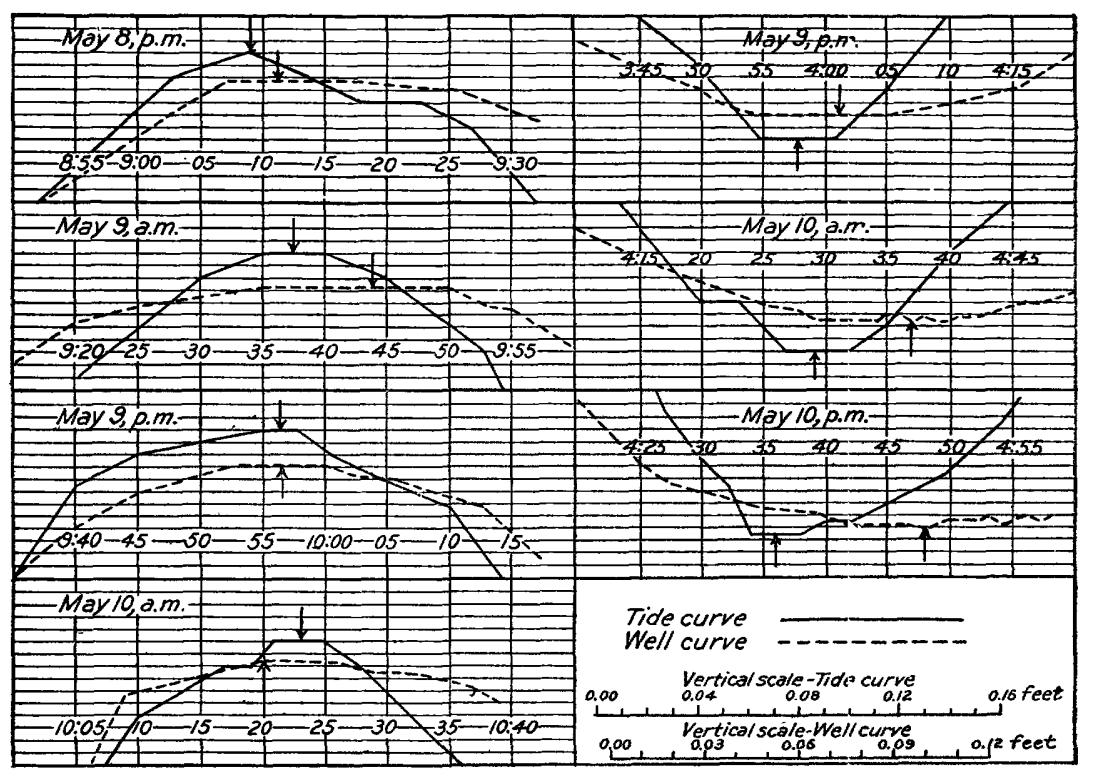

FIG. 3.-Details of well and tide curves at Huntington Harbor, N. Y., showing lag between well and tide. From observations with direct-reading floats by A. C. Veatch and Isaiah Bowman.

which, when a free escape to the surface is afforded, as by a well tube, causes a flowing well. The blue-clay layer reported probably represents the feather-edge of a sheet which thickens under the harbor, but does not extend reyond it. This is inferred from the general geologic relations of the region.

A board gage divided to tenths of a foot was placed on the north sicle of the platform pier at the point marked "Gage No. 1" in fig. 2. There was relatively still water at this point, and the oldest inhabitant stated positively, when the board was placed, at about $6 \mathrm{p}$. m. on May 8, that the foot of the gage would not be exposed at low water. Observations were at once begun on the well and tide gage, and continued until 3 o'clock on the morning of May 9, when at low tide the bottom of the gage was exposed. The gage was then moved to point No. 2, sorth of the platform pier, and the observations continued from 7.38 a. m. May 9 to 7.30 p. m. May 10 , and thus four high and three low waters were compared. 
The bench mark established was as follows: Cross on top of south end of doorsill, west side of building of Huntington Light and Power Company. The elevation above the zero of gage No. 2 is 12.232 feet.

The observations here gave curves of the same general character as those at Oyster Bay (fig. 8, p. 16).

The two curves are essentially parallel, and while the semidiurnal range of the tide is about 8 feet, that of the well is about 2 feet. The low water in the well is 3.5 -eet above the highest water in the bay.

In fig. 3 the high-and low-tide readings for both the well and the tide hr.ve been plotted on a large scale, with the same time values, but with different vertical values, in order to bring out the amount of time the fluctuations in the well lag behind those of the tide. These curves indicate that for the period of observation the lov tide in the well has an average establishment, or lag behind the ocean waters, of two minutes and the high tide eight minutes.

On May $11 \mathrm{Mr}$. Isaiah Bowman made observations with the direct-reading floats on a shallow 6-inch flowing well belonging to the Consolidated Ice Company, at Huntington. It is located about a mile from the harbor, at an elevation of 40 feet. The observations were continued for six hours and no fluctuations of any character noted.

OBSERVATIONS AT OYSTER BAY, N. Y.

During the month following the observations at Huntington Harbor it wes found that among the many flowing wells at Oyster Bay four could be observed for a limited time.

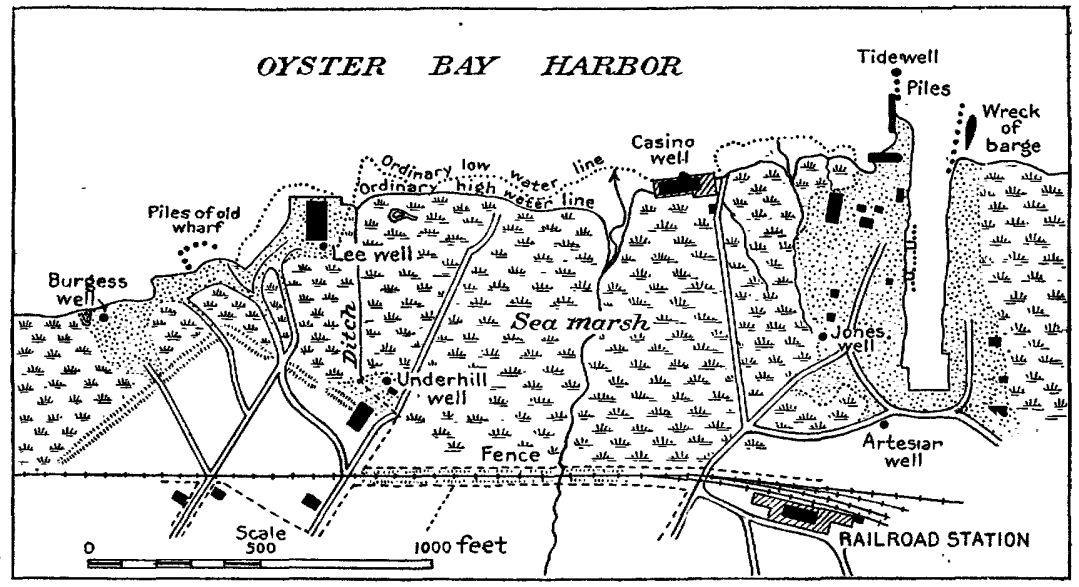

FIG. 4.-Sketch map showing location of wells observed at Oyster Bay, N. Y.

These wells are all very near the shore; indeed, the Casino well, which is beneath the floor of a building extending over the water, is always covered at high tide (fig. 4). The others, the Burgess, Lee (or Hill), and Underhill wells (fig. 4), are at distances of from 50 to 500 feet from ordinary high-tide mark, though the ground at all is covered when extraordinary wind-aided tides occur. The depths of these rells, as determined by soundings at the time of the observations, were: Casino, 93 feet; Underhill, 114 feet; Lee, 188 feet; Burgess, 155.5 feet. The Casino and Lee are 3-inch wells, and the Burgess and Underhill 2-inch wells. All these wells pass through a surface layer of sand and gravel, then a layer of blue clay 50 to 75 feet thick, and finally penetrate a rather coarse water-bearing sand. In some cases the uppor sands and gravels will furnish flowing water, but all the wells observed obtain their supply 
from below the blue-clay layer (fig. 6). This blue clay thins rapilly southward and entirely disappears half a mile south of the wells (fig. 7). It extınds under Oyster Bay Harbor and is exposed in the clay pits on the south end of Cinter Island. $a$

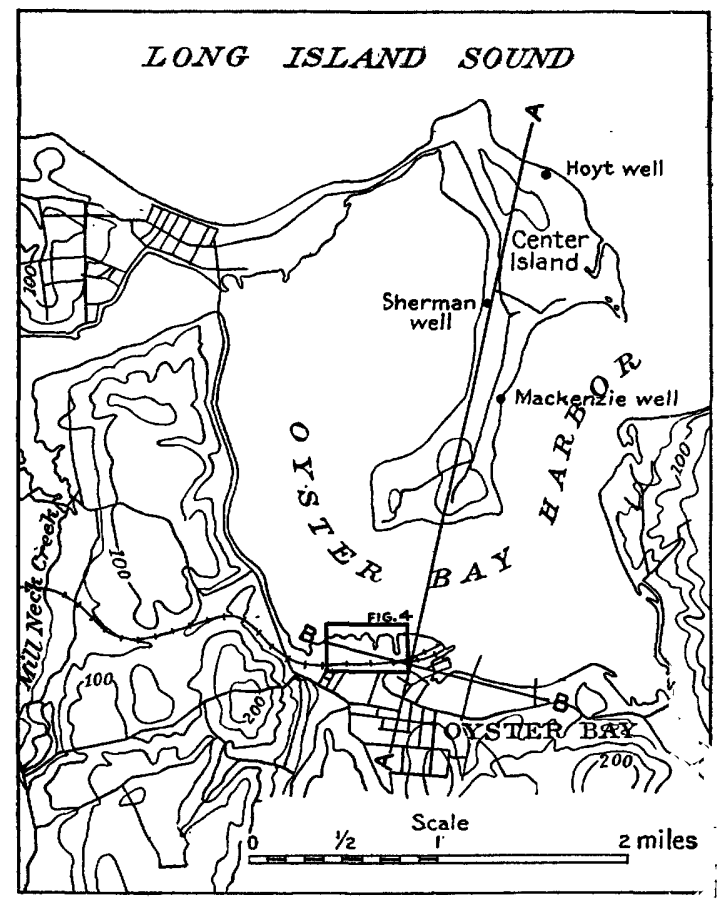

FIG. 5.-Sketch map showing topographic surroundings of vells shown in fig. 4 and location of sections show $n$ in figs. 6 and 7.

All these wells were flowing, and in each case, before observations were commenced, lengths of pipe were added until the wells no longer flowed, even at high tide. Float gages similar to those used at Huntington were then inserted and the wells covered

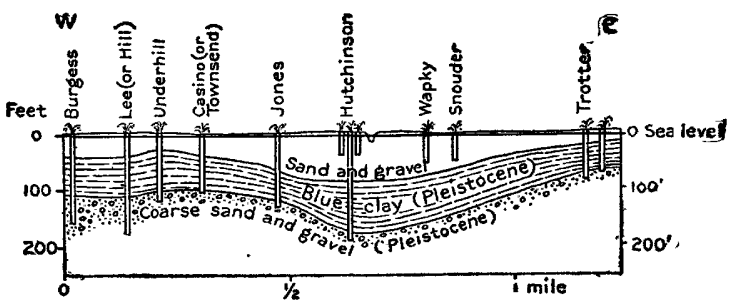

Fig. 6.-Section at Oyster Bay, N. Y., along line B-B, fig. 5, sh owing geologic relations of wells observed.

with flat-topped caps, each containing a smooth beveled hole through which the gage rod extended. $b$

$a$ The folding of the beds here shown is due to ice shove. See Prof. Paper U. S. Geol. Survey No. 44, 1906, pp. 39-43.

$b$ The general conditions of observation are well shown in Prof. Paper U. S. Genl. Survey No. 44, 1906, P1. XIII, $A$. This view indicates, in a very graphic manner, the relation of th 9 wells to the water of the bay and the considerable head developed by these fresh-water artesian wells on the seashore. 
In order to obtain more refined results than were possible with the board gage at Huntington, a 3-inch pipe, perforated at a point several feet above the bottom, was driven in the harbor at the end of a row of piles and at a distance of about 200 feet

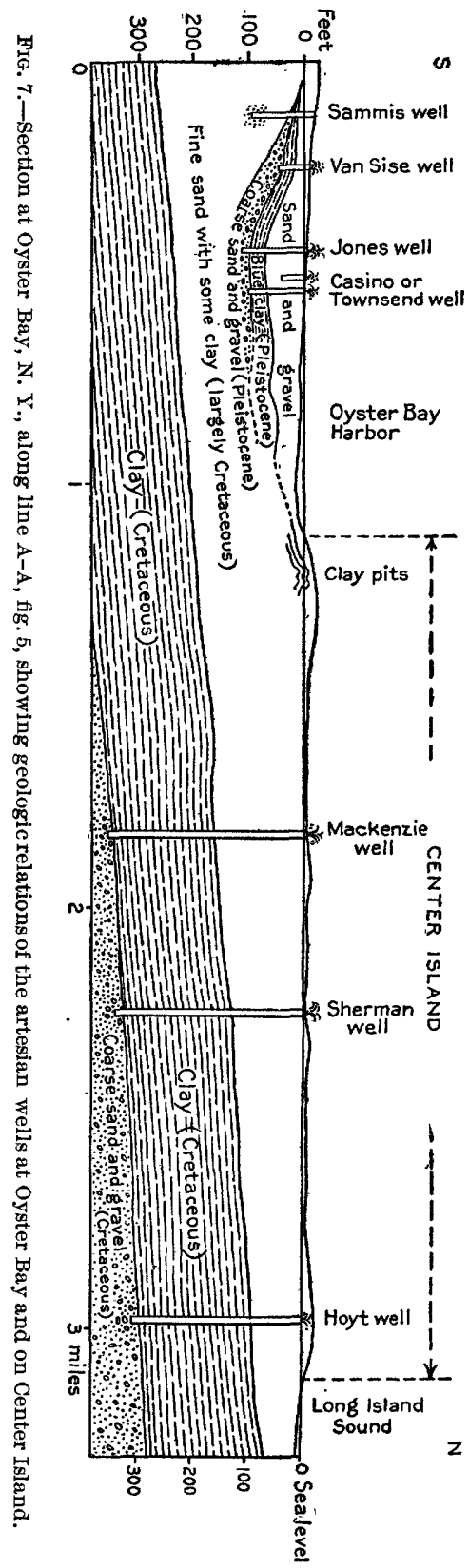

from the shore (fig. 4). This still box or tide well was fitted with a direct-reading float gage like those used in the artesian wells. This arrangement is not to be recommended during stormy weather, but fortunately during the whole time of observation at this place no trouble was experienced from that cause. 
Observations were commencerl on the Casino, Underhill, and Burgess wells on the evening of May 30, by a party in charge of Mr. Isaiah Bowman, and continued, with interruptions on the nights of May 30 and 31 and June 1, to 10 p. 1 . on June 4 .

On June 10 and 11 observations were made on the Lee (or Hill) well, covering two high and two low tides, and for the purpose of comparison the Casino and tide wells were also observed. Observations were generally made every minute for thirty minutes preceding and following the times of high and low water, and from these values the curves shown in fig. 8 were drawn. Times of high and low water were found by plotting the observations near high- and low-tide marks on a much larger scale, in the manner shown in fig. 3 . The values so obtained are indicated on fig. 8 , and are given in the following tabie:

Difference in time between high: and low-water stages in four artesian wells at Oyster Buy, N. Y., and the tide in Oyster Bay Harbor.

[Time expressed in hours and minutes of 24-hour clock.]

HIGH TIDES.

\begin{tabular}{|c|c|c|c|c|c|c|c|c|c|c|c|c|}
\hline 1903. & $\begin{array}{c}\text { May } \\
30 .\end{array}$ & May & 31. & $\begin{array}{c}\text { June } \\
1 .\end{array}$ & Jun & e 2. & Jun & e 3 . & Juns & June & June & $\begin{array}{l}\text { Aver- } \\
\text { age }\end{array}$ \\
\hline & & & & & & & & & & & & $\begin{array}{l}\text { Min- } \\
\text { utes. }\end{array}$ \\
\hline Casino well.. & & $\ldots \ldots$. & 14.52 & & . & 17.05 & 5.19 & 18.11 & 6.38 & & 12.22 & \\
\hline Tide............. & & $\ldots \ldots$. & 14.43 & 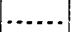 & ...... & 16.54 & 5.12 & 18.02 & 6.29 & . & 12.20 & \\
\hline Difference (lag) & & ...... & .09 & 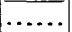 & & .11 & .07 & .09 & .09 & -. & .02 & 0.8 \\
\hline Burgess well. & & & 15.13 & 16.05 & & 17.15 & 5.38 & 18.25 & 6.56 & & & \\
\hline Tide $. . . \ldots, \ldots \ldots$ & & ... & 14.43 & $\mid 15.44$ & .. & T6. 54 & 5.12 & 18.02 & 6.29 & . & ... & \\
\hline Difference (lag) . & & $\ldots \ldots$ & .30 & .21 & & .21 & .26 & .23 & .27 & & $\cdots$ & 24.7 \\
\hline Lee well. & & & & & 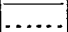 & & & & ... & $a 0.20$ & 13.12 & \\
\hline Tide... & & & & & & & $\ldots$ & $\ldots .$. & $\ldots$ & 23.48 & 12.20 & \\
\hline Difference (lag & & ...... & ....... & $\ldots$ & & $\ldots \ldots$ & ....... & $\overline{\ldots . . .}$ & $\overline{\ldots \ldots}$ & .32 & .52 & .42 \\
\hline Underhill well & & & $\overline{16.02}$ & $\overline{17.02}$ & & $\overline{18.00}$ & 6.20 & 19.10 & 7.41 & & & \\
\hline Tide... & & & 14.43 & 15.44 & . & 16.54 & 5.12 & 18.02 & 6.29 & & & \\
\hline Difference (lag) & & & 1.19 & 1.18 & & 1.06 & 1.08 & 1.08 & 1.12 & & & 71.8 \\
\hline
\end{tabular}

LOW TIDES.

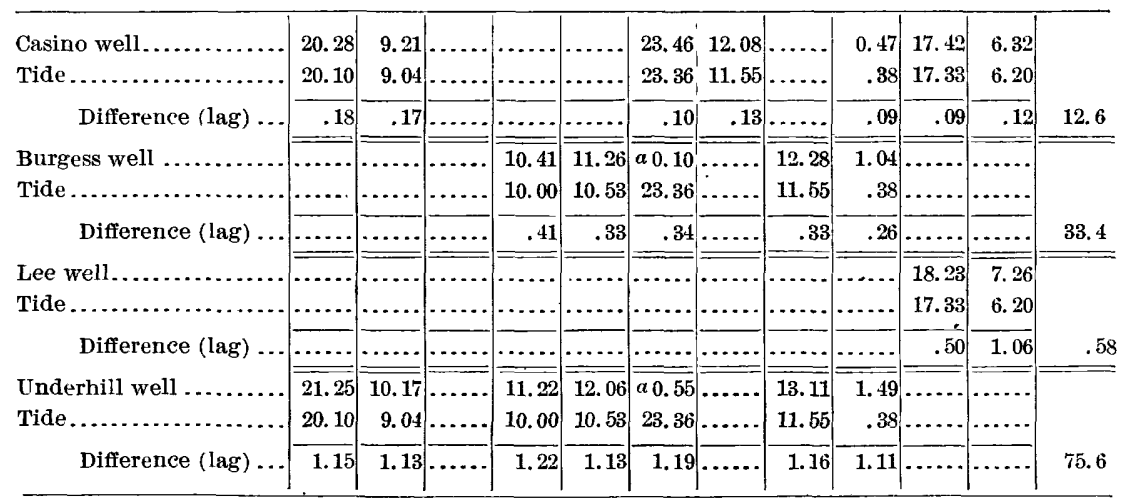

$a$ Morning of following day. 


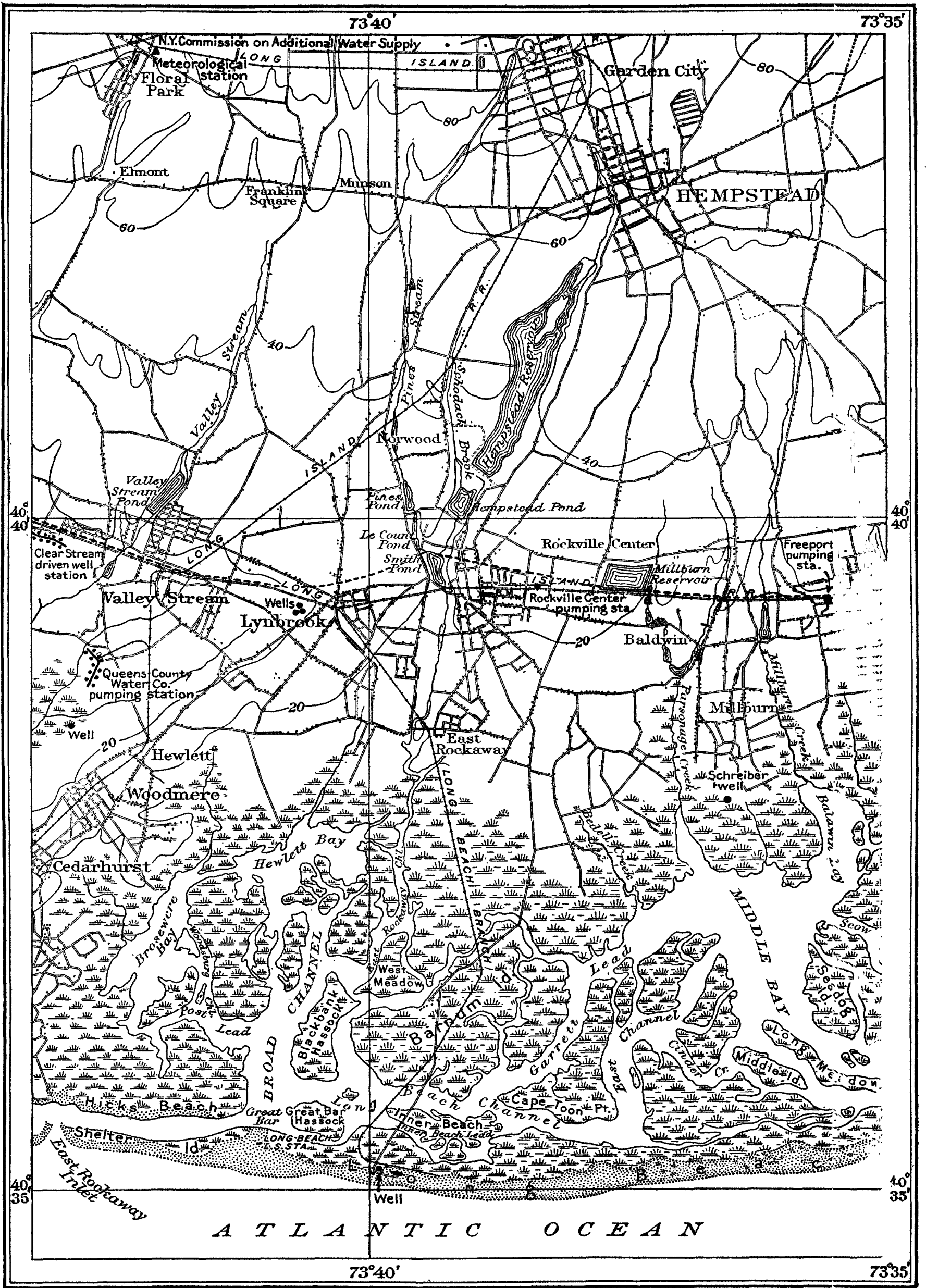

$11 \frac{}{1 / 2} \quad$ Scale ofmiles 1


OBSERVATIONS WITH SELF-RECORDING GAGES. INSTRUMENTS USED.

The continuation of the observations by means of self-recording gages was due to the timely interest of Mr. F. H. Newell and Prof. Charles S. Slichter. Mr. Newell

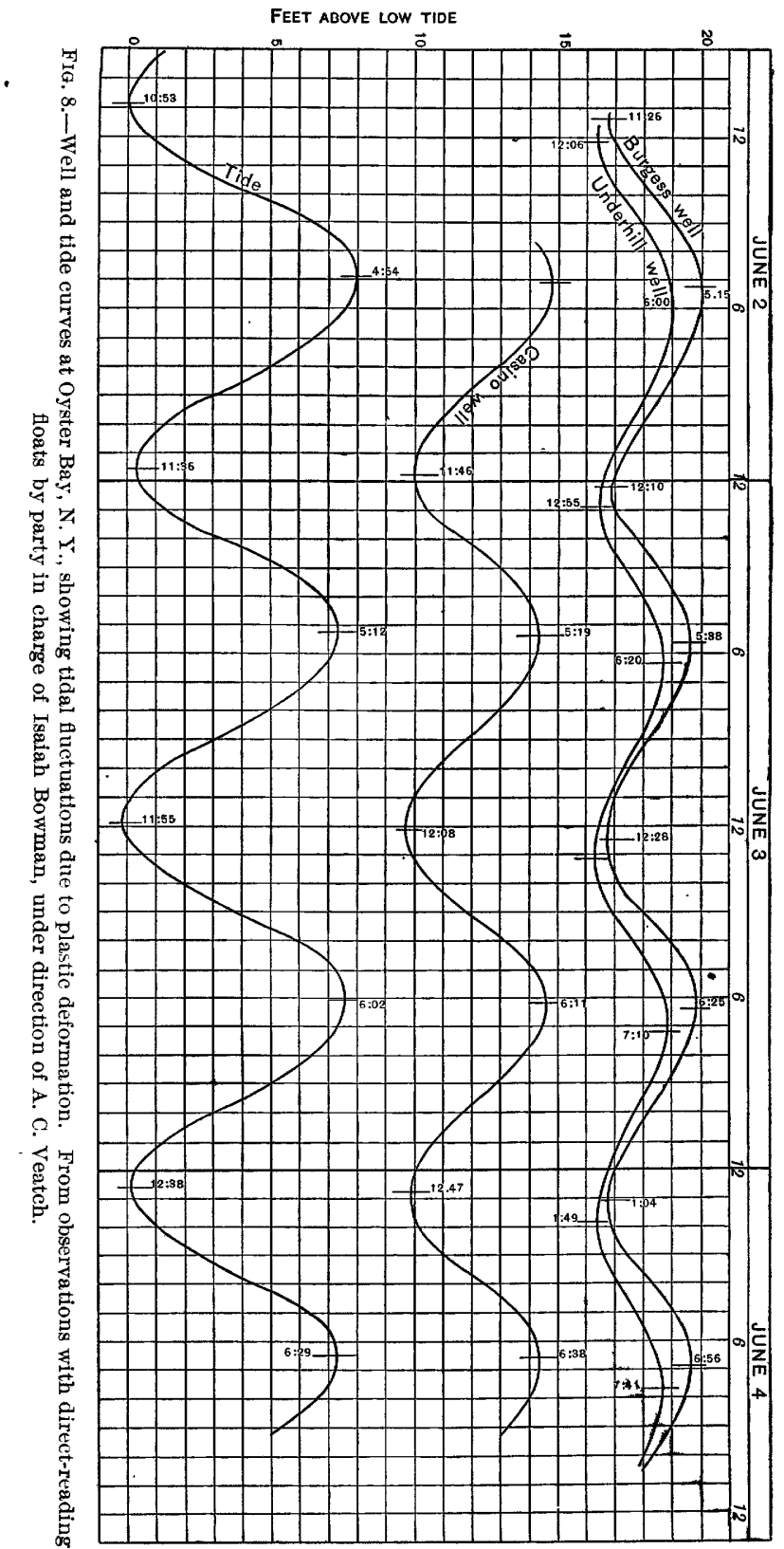

visited the island when the observations at Oyster Bay were in progress, and at once airected that three Friez water-stage registers be purchased. These were suppleIRR $155-06-2$ 
mented by a gage constructed at Purdue University from the designs of Mr. Elwood Mead.

Shortly after Mr. Newell's visit, and before the Friez gages had been received, Prof. Charles S. Slichter arrived to take charge of the measurement of the rate of underflow. He kindly obtained the loan of five of the gages ured by King in his experiments at Madison, Wis.; * of these, four were week gages and one a one-day gage. The King gages were constructed by H. Green, Brooklyn, from barograph stands; they consist of an ordinary barograph cylinder, driven by a double-spring marine clock, the recording device being a simple lever on a cone bearing with a pen on one end and a place for attaching the float on the other. At the point where the clock motion is transmitted to the drum there was a slight amount of play which King found would introduce into the records an error of one to two hours. A friction brake was, however, subsequently added to overcome this defect. The gages as received on Long Island were adjusted to magnify the fluctuations two or more times; and as this scale was entirely too great for the wells obse"ved, the arm was extended until the ratio was 1:2 and a reduction of one-half thereby obtained. These gages were found to be more sensitive and reliable than any others used. By means of the simple lever with its cone bearing, the friction in this instrument is reduced to a minimum; the pens respond to the slightest movement of the water, and for the faithful reproduction of small fluctuations this simpls type of gage is to be highlly recommended.

In the Mead gage the recording drum is vertical and the pen is carried by a carriage working between two upright guides. The wire supporting the carriage winds about a wheel connected with the wheel around which a wire from the float passes, and is lifted and lowered as the float descends and rises. The float and the wheel to which the pen is attached are so related in diameter that the curve traced is $10 / 42$ of the true scale. There is with this gage, as with most gages where the recording cylinder is driven by the clock; some lost motion at the point of connection. This is particularly bad in this instrument. On the Long Beach records great care was used in setting the gage and the trouble was avoided, but some of the curves from well No. 8, at Douglaston, are clearly in error two to three hours.

In the Friez gage $b$ the recording drum is horizontal and is moved by the float, while the pen is moved by the clockwork. It was found that with the size of float that must be used in wells of small diameter the inertia of the d"um in this instrument was such that it would not move until considerable head was developed and that small fluctuations were often not recorded. There was slso a considerable amount of lost motion in the cogs used in the reducing device; and while an eccentric was provided for engaging the cogs closer, this could not be done without so increasing the friction that the instrument was useless. As a whole, this gage is not sufficiently sensitive for this kind of work, and the time element is entirely too small.

A water-stage register manufactured by a western house was also used, but the results obtained were not satisfactory because of the poor mechanical construction of the gage.

OBSERVATIONS ON WELL OF QUEENS COUNTY WATER COMPANY, 1 MILE WEST OF HEWLETT, $N$. Y.

Through the kindness of the chief engineer of the Queens County Water Company, Mr. Charles R. Bettes, an artesian well 181 feet deep and 3,300 feet south of the company's pumping station (PI. II) was covered with a shelter for the protection of the gages and placed at the disposal of the Survey. This well, as is common with . the wells of about the same depth sunk near the pumping station, passes through a layer of surface sand and gravel, then through beds of clay and other fine material 


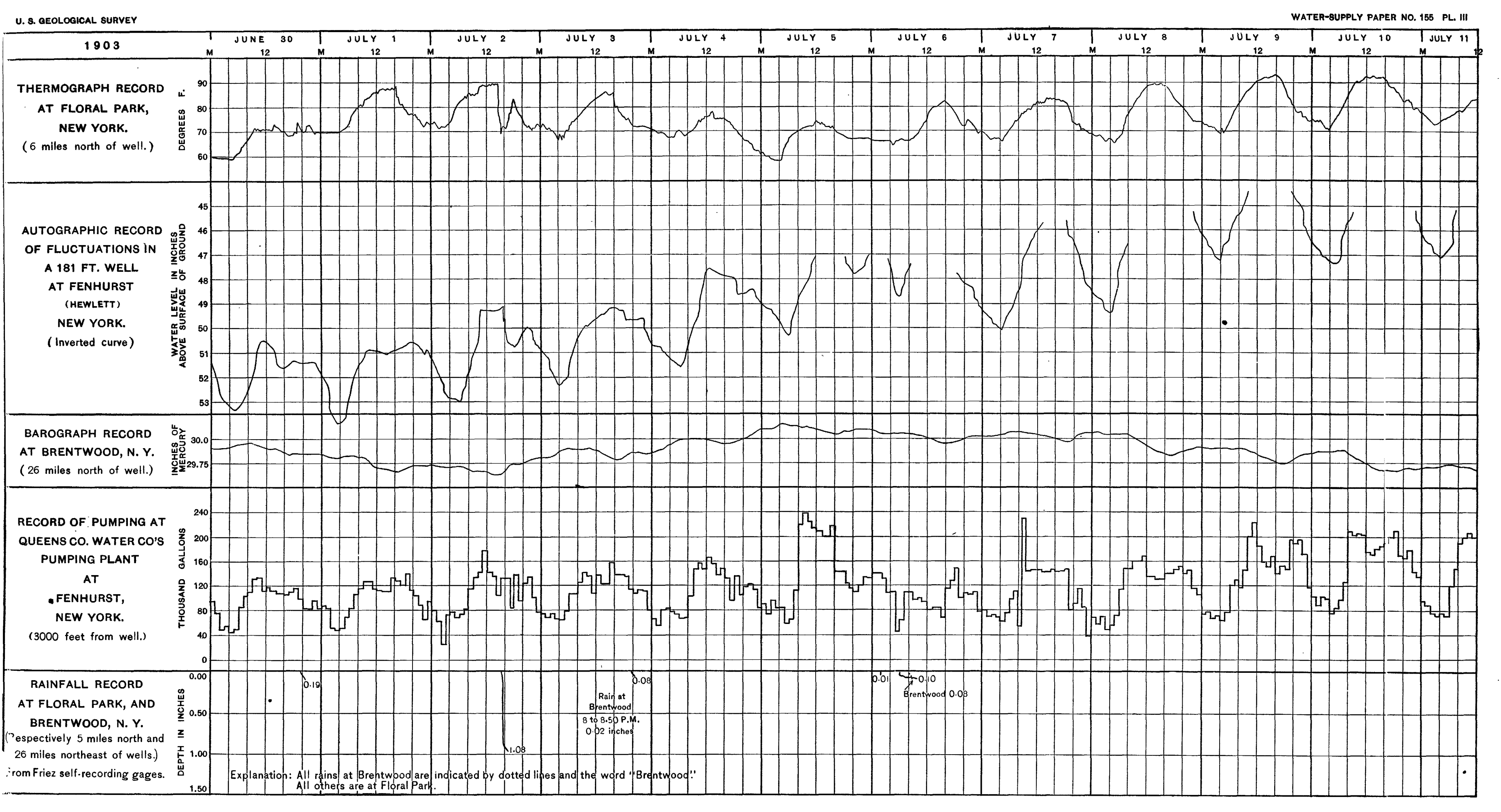


into a rather coarse gravel, which yields an abundant supply of flowing water. $a$ The whole section is of Pleistocene age. There are in the immediate vicinity of the pumping station thirty-two 5 -inch wells, 33 feet deep, and nineteen 6 -inch vells, 150 to 190 feet deep. These are arranged along two lines, one extending northwest and the other southwest from the pumping station. The extreme end of the south line is about 1,000 feet from the pumping station, and the well observed is therefore over 2,000 feet from the nearest pumped well and but slightly to one side of the probable direction of flow. (Pl. II.) It was the opinion of Mr. Bettes that this wel was not affected by pumping, and through a misinterpretation of the first records it was believed that this surmise was correct. Considerable discussion was therefore caused when it was found that the well fluctuations simulated the thermograph $\mathrm{cr}^{\text {rve }}$ in a remarkable manner, that these fluctuations were inversely related to the temperature (a rise in temperature causing a fall in water), and that the changes monifested themselves with a lag of but one or two hours behind apparently similar temperature fluctuations. (Pl. III.)

The hourly pumpage was kindly furnished by Chief Engineer Bettes, and this record, when plotted with the well curves, conclusively demonstrated that the rhythmical fluctuations were due more to pumpage than to temperature (Pl. III). Fluctuations of a somewhat similar character are produced by temperature changes (see p. 54), and this element is doubtless present in this curve. On Pl. III the effect of pumpage is clearly shown in the double cusps of the well curves on the night of July 5-6. The temperature curve shows no such variations. Similarly, the records on June 21,25 , and 26 show important differences between the well and ter perature curves, which are largely due to pumping. These results are important bocause of the rapid rate of transmission. The effect of this pumping is felt at a distance of 2,000 feet or more, with a time lag of but one or two hours. This contrasts sharply with the very slow transmission noted in the pressure changes due to tidal loading and to the inflow and outflow along rivers (see pp. 60,65). It conclusively proves that the supply here is large; that the beds are quite porous, and that the normal water flow is rapid.

In the records from the day gage, which was maintained here for the first ten days, the larger time scale brought out very clearly a series of regular minor fluctuations which were not clearly defined with the smaller scale of the week records. The most pronounced of this series recurs day after day and has a period of very nearly twenty minutes and a range of 0.06 to 0.08 inch.

Besides these vibrations, with a period of twenty minutes, there are several fluctuations of smaller amplitude and period. One series has a period of about five or six minutes, but it is so involved that little can be definitely stater regarding it. An instrument with a large time scale, 1 or 2 inches to the hour, and a vertical scale of once or twice the normal would record, at this place, a very complicated series of small recurrent vibrations.

OBSERVATIONS AT LONG BEACH, N. Y.

The deep flowing well of the Long Beach Association at Long Beach, N. Y. (Pl. II), offered a most excellent opportunity for the observations of tidal fluctuations. It is situated on a narrow, sandy barrier beach, separated from the main ivland by a sea marsh 2 to 3 miles wide, cut by narrow tidal channels, and is entirely removed from the influence of any pumping station.

This well is 3 inches in diameter and 386 feet deep. The water is obtained in sands of Cretaceous age and rises 2 to 4 feet above the surface of the ground or 10 to 12 feet above sea level. The general geologic relations may be inferred from the diagrammatic cross section given in fig. 1 (p. 9).

$a$ For detailed reeord of strata in near-by wells see Prof. Paper U. S. Geol. Survey No. 44, 1966, p. 225. fig. 66 . 
The section reported by the driller, Mr. W. C. Jaegle, is as follows:

Section of well of Long Beach Association, at Long Beach, N. Y.

1. White sand .................................................. 36

2. Dark sand and creek mud ................................. 36- 40

3. White gravel, containing salt water....................... $40-51$

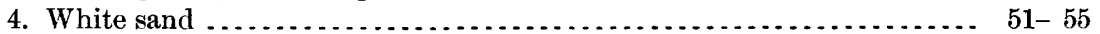

5. Dark sand . . . . . . . . . . . . . .

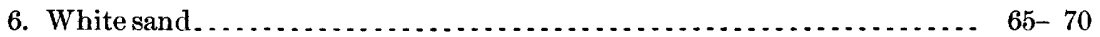

7. White gravel ............................................... $70-73$

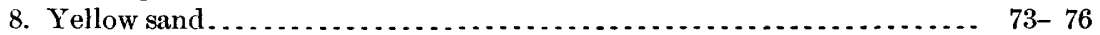

9. Blue clay ................................................ $76-82$

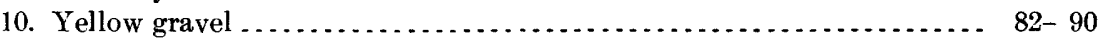

11. Creek mud .............................................. $90-99$

12. Dark fine sand, containing lignite.......................... 99-101

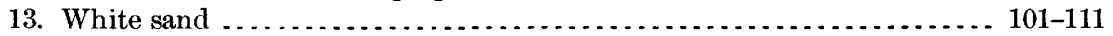

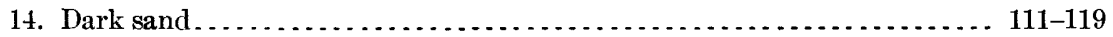

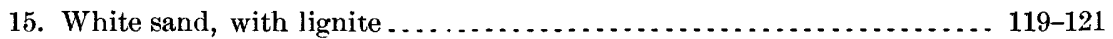

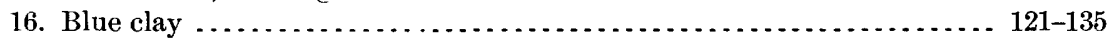

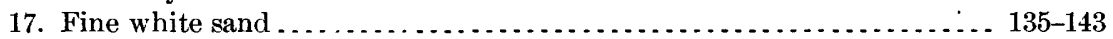

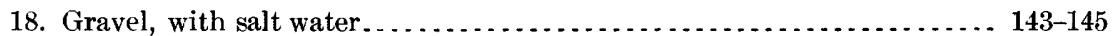

19. Dark sand . . . . . . . . . . . . . . . . . . . . . . . . . . . . . . . . . . . $145-156$

20. Gravel, with salt water.................................. 156-158

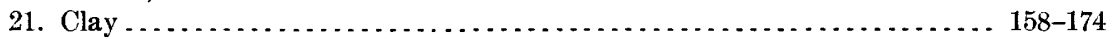

22. White sand, containing at 190 feet a log of lignitized wood ........ . . 174-192

23. White gravel and salt water .............................. 192-196

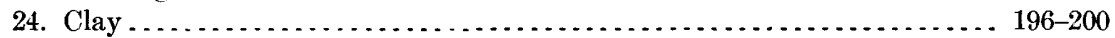

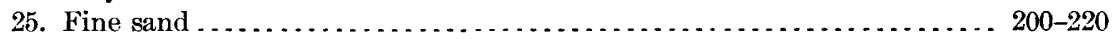

26. Solid blue clay . . . . . . . . . . . . . . . . . . . . . . . . . . . . . . . . 220 270

27. White sand and wood, containing fresh water, sweet and chalybeate... 270-276.

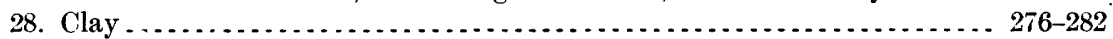

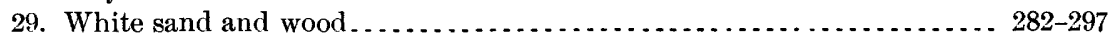

30. Blue clay ........................

31. White sand, wood, and water . . . . . . . . . . . . . .

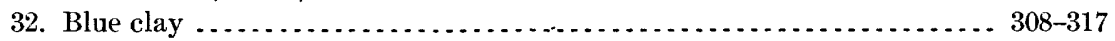

33. White sand, containing wood and artesian water.............. 317-325

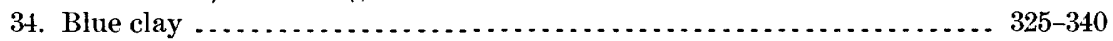

35. White sand and mineral water; has considerable $\mathrm{CO}_{2}$, sparkling and effervescent ................................................. 340-356

36. Blue clay ..............

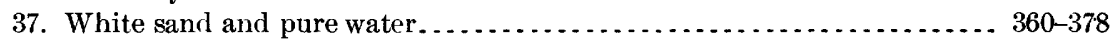

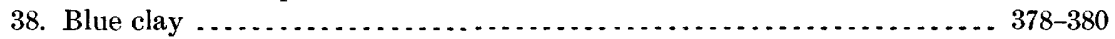

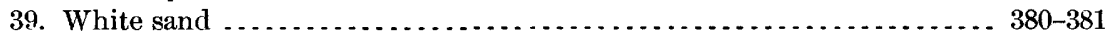

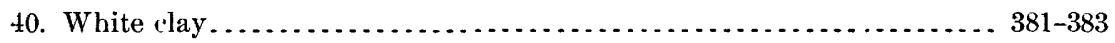

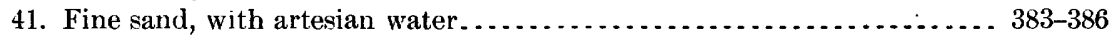

Mr. F. D. Rathbun was placed in charge of these observations and by a careful readjustment of the Mead gage obtained very excellent curves (PI. IV). Indeed, for this character of work the results from the Mead gage, as set up by Mr. Rathbun, are better than from the Friez gage.

It was impossible to make tide observations at this point, and the values plotted on the curve are taken from those predicted by the Coast and Geodetic Survey $a$ f.r East Rockaway Inlet, which is 2.8 miles west of the well. The difference in time 

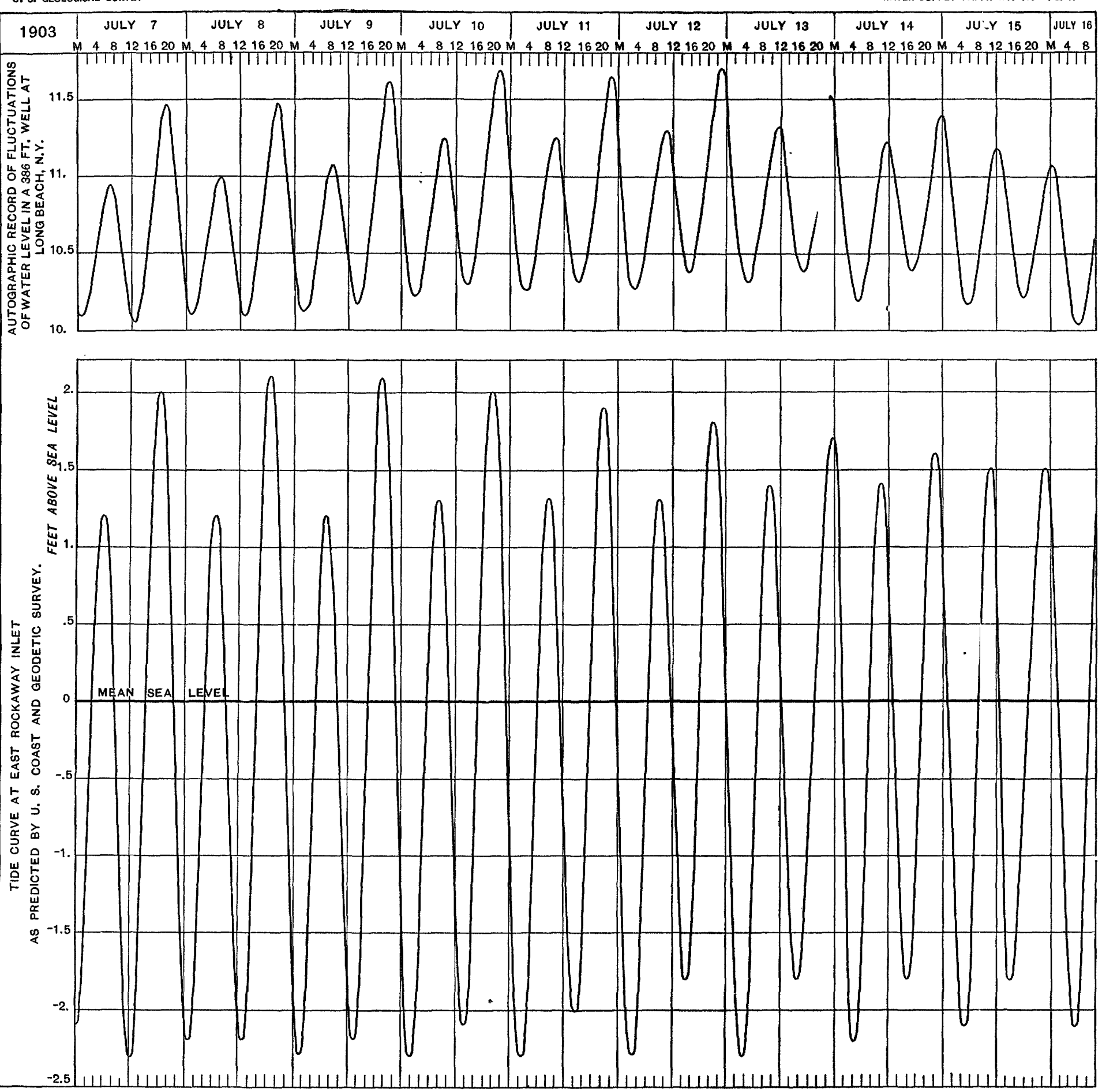

PARTIAL RECORD OF FLUCTUATIONS OF WATER LEVEL IN A 386-FOOT WELL AT LONG BEACH, $N$. $Y$. 


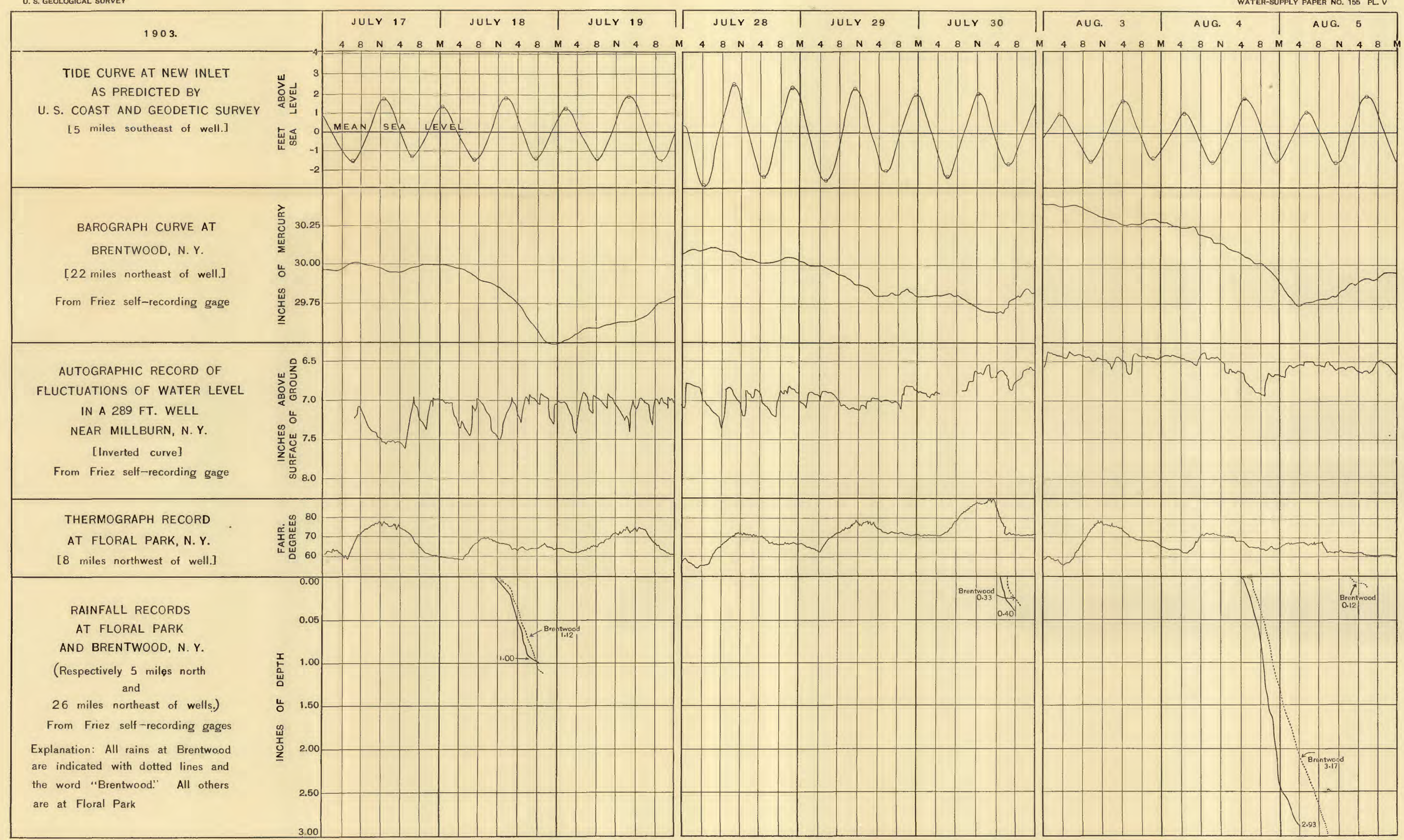

PARTIAL RECORD OF FLUCTUATIONS OF WATER LEVEL IN A 289-FOOT WELL NEAR MILLBURN, N. Y. From a King gage in charge of Francis $L$. Whitney and F. D. Rathbun, field assistants. Well curve is inverted. 

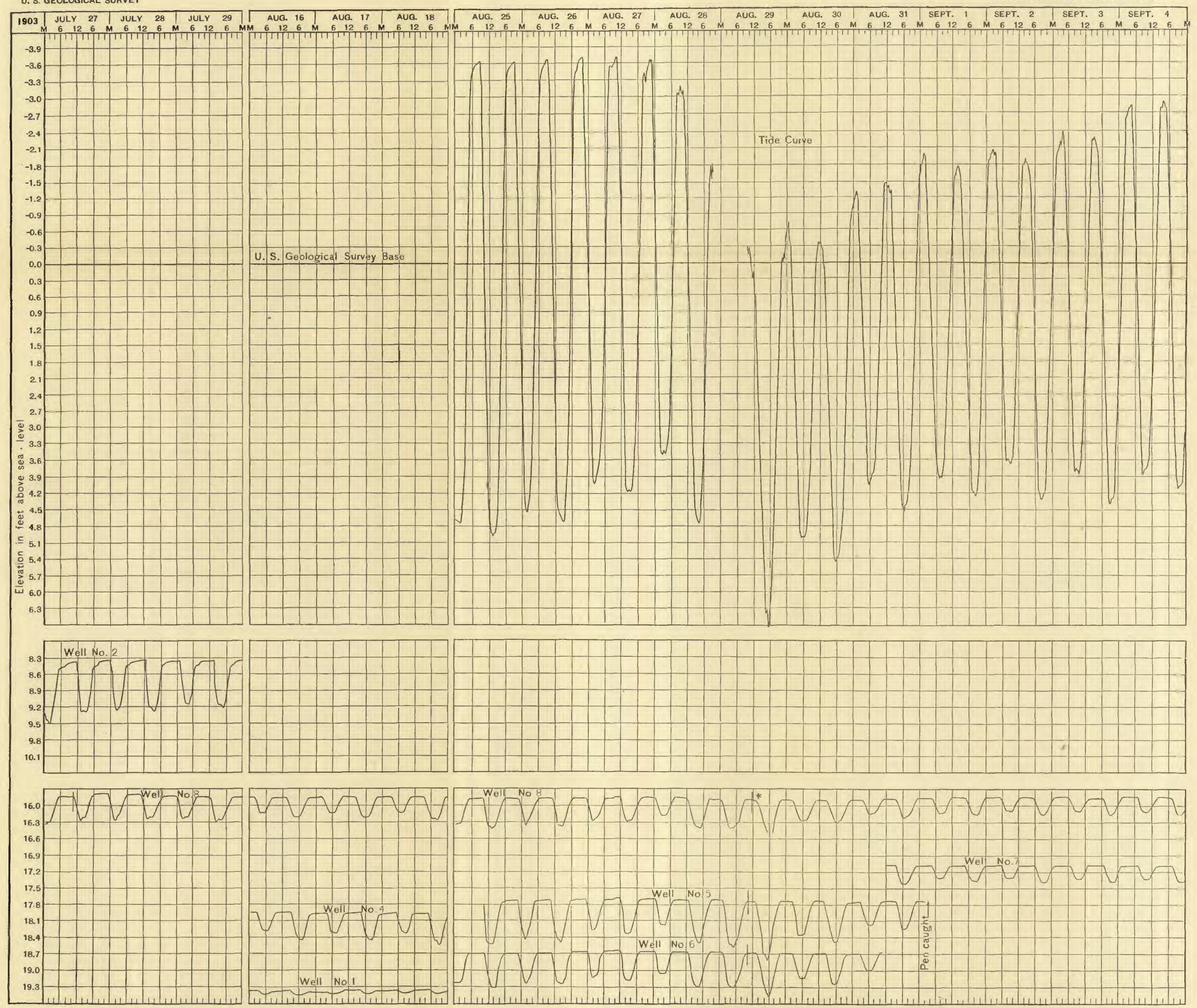

PARTIAL RECORD OF FLUCTUATIONS OF WATER LEVEL IN WELLS NEAR DOUGLASTON, $N$. Y, AND OF TIDE IN ADJOINING CREEK

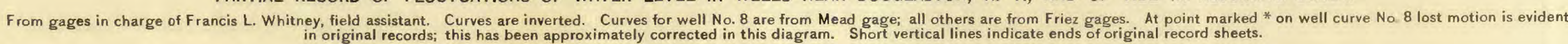


between the tide at this point and on the beach in front of the well is probably not more than two or three minutes, since at New Inlet, 5.3 miles east of the vell, high and low tides occur only from four to six minutes earlier than at East Rockavay Inlet.

The data regarding the tidal fluctuations in the channel behind Long Beach are very meager. Mr. Paul K. Ames, of the Long Beach Association, through whose kindness it was possible to make observations on this well, states that the smplitude of the tide in Broad and Long Beach channels is about 4 feet, or the average of the fluctuations in the open ocean at this point, and that in the tides behind Long Beach there is a lag of about one hour.

Observations a few miles to the west in Jamaica Bay, which is separated from the main ocean by a sand bar similar to that at Long Beach, show that at various points behind the bar the high and low water are from thirty-two to eighty minutes behind the same stages in the ocean, and that the lag at high water is less by from six to thirty minutes than at low water. $a$ It may be confidently affirmed that a similar lag occurs in the channels behind Long Beach.

The well curve obtained is a very smooth curve, which is apparently the simple resultant of the tides in the ocean and those inside of the bar. The extreme regularity of the low-tide values is believed to be due to the modifying influence of the tides in the inner channels, which, because of the shallow character of the outlets into the ocean, would have a much smaller low-tide variation than the ocean. The lag of the high and low waters in the well, compared with the ocean tide, is given in the following table:

Table showing difference in time between high and low water in a 386-foot well at Long Beach, N. Y., and the tide as predicted by the United States Coast and Geodetic Survey for East Rockaway Inlet (Pl. IV).

\begin{tabular}{|c|c|c|c|c|c|c|}
\hline \multirow{2}{*}{ Date. } & \multicolumn{3}{|c|}{ High water. } & \multicolumn{3}{|c|}{ Low water. } \\
\hline & Well. & Tide & $\begin{array}{l}\text { Differ- } \\
\text { ence. }\end{array}$ & Well. & Tide & $\begin{array}{l}\text { Differ- } \\
\text { ence. }\end{array}$ \\
\hline \multirow{4}{*}{$\begin{array}{l}\text { June } 3 \\
\text { July } 1\end{array}$} & Time & Time & $\begin{array}{c}\text { Hours } \\
\text { and man- } \\
\text { utes }\end{array}$ & Time & Time & $\begin{array}{c}\text { Hours } \\
\text { and min- } \\
\text { utes. }\end{array}$ \\
\hline & - $\cdots \cdot$ & ....... & ....... & 1830 & 18. 09 & 0.21 \\
\hline & 1. 20 & 0.13 & 1.07 & 7. 00 & 6.36 & 0.24 \\
\hline & . & 12.53 & $\ldots .$. & 19.50 & 19. 10 & 0.40 \\
\hline \multirow{2}{*}{ July $2 \ldots \ldots \ldots \ldots \ldots \ldots \ldots \ldots \ldots \ldots \ldots \ldots \ldots \ldots \ldots \ldots \ldots$} & 2.20 & 1.10 & 110 & 800 & 732 & 0.28 \\
\hline & 15. 20 & 1352 & 1.28 & 2050 & 2014 & 0.36 \\
\hline \multirow[t]{2}{*}{ July $3 \ldots \ldots \ldots \ldots \ldots \ldots \ldots \ldots \ldots \ldots \ldots \ldots \ldots \ldots \ldots \ldots$} & 320 & 2.13 & 1.07 & 920 & 8.25 & 0.55 \\
\hline & 16.10 & 14.49 & 1.21 & 2200 & 21.16 & 0.44 \\
\hline \multirow[t]{2}{*}{ July $4 \ldots \ldots \ldots \ldots \ldots \ldots \ldots \ldots \ldots \ldots \ldots \ldots \ldots \ldots \ldots \ldots \ldots$} & 4.05 & 3.13 & 0.52 & 10. 30 & 9.26 & 1. 04 \\
\hline & 17. 05 & 15.46 & 1.29 & ...... & $\ldots$ & $\ldots$ \\
\hline \multirow[t]{2}{*}{ July $7 \ldots \ldots \ldots \ldots \ldots \ldots \ldots \ldots \ldots \ldots \ldots \ldots \ldots$} & 7.05 & 5.58 & 107 & 040 & 23.59 & 0.41 \\
\hline & 19.25 & 18.14 & 1.11 & 1220 & 11. 59 & 0.21 \\
\hline \multirow[t]{2}{*}{ July $8 \ldots \ldots \ldots .}$. & 7.35 & 6.44 & 0.51 & 1.10 & 0.44 & 0.26 \\
\hline & 2010 & 1355 & 1,15 & 1250 & 12.44 & 0.06 \\
\hline July 9 . & 8.35 & 7.25 & 1.10 & 2.00 & 1.24 & 0.36 \\
\hline - & 20.50 & 19.34 & 1.16 & 13. 55 & 13.24 & 0.31 \\
\hline \multirow[t]{2}{*}{ 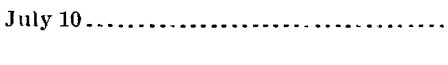 } & 9.15 & 8.03 & 1.12 & 2.50 & 2.02 & 0.48 \\
\hline & 21.35 & 20.11 & 1.24 & 14.35 & 14.04 & 0.31 \\
\hline \multirow[t]{2}{*}{ July $11 \ldots \ldots \ldots \ldots \ldots \ldots \ldots \ldots \ldots \ldots \ldots \ldots \ldots \ldots \ldots \ldots \ldots$} & 9. 55 & 8.38 & 1.17 & 3.20 & 2.36 & 0.44 \\
\hline & 22.05 & 20.46 & 1.19 & 15.15 & 14.38 & 0.25 \\
\hline \multirow[t]{2}{*}{ July $12, \ldots \ldots \ldots \ldots \ldots \ldots \ldots \ldots \ldots \ldots \ldots \ldots$} & 10.40 & 9.09 & 1.31 & 3.40 & 3.11 & 0.29 \\
\hline & 23. 05 & 21.19 & 1.46 & 15. 35 & 15.09 & 0.26 \\
\hline
\end{tabular}

a U. S. Coast and Geodetic Survey Tide Table for 1903, p. 346. 
Table showng difference in time between high and low water in a s85-foot well at Long Beach, N. Y., and tide at East Rockaway Inlet-Contir'red.

\begin{tabular}{|c|c|c|c|c|c|c|}
\hline \multirow[b]{2}{*}{ Date. } & \multicolumn{3}{|c|}{ High water. } & \multicolumn{3}{|c|}{ Low water. } \\
\hline & Well. & Tide. & $\begin{array}{l}\text { Differ- } \\
\text { ence. }\end{array}$ & Well. & Tide. & $\begin{array}{l}\text { Differ- } \\
\text { ence. }\end{array}$ \\
\hline 1903. & Time. & Time. & $\begin{array}{l}\text { Hours } \\
\text { and min- } \\
\text { utes. }\end{array}$ & Time. & Time. & $\begin{array}{l}\text { Hours } \\
\text { and min- } \\
\text { utes. }\end{array}$ \\
\hline July $13 \ldots \ldots \ldots$ & 11.50 & 9.44 & 2.06 & $\begin{array}{r}4.5 \mathrm{C} \\
\quad-55\end{array}$ & 3.44 & 1.06 \\
\hline Tulv 14 & 23.00 & 21.54 & $\begin{array}{l}1.06 \\
1.19\end{array}$ & $\begin{array}{r}16.55 \\
5.10\end{array}$ & $\begin{array}{r}15,44 \\
4.19\end{array}$ & $\begin{array}{l}1.11 \\
0.51\end{array}$ \\
\hline & 23.45 & 22.28 & 1.17 & 17.10 & 16. 21 & 0.49 \\
\hline July 15 . & & & & 5.55 & 4. 55 & 1.00 \\
\hline & 12.20 & 11.03 & 1.07 & 18.00 & 17.04 & 0.56 \\
\hline July $16 \ldots$ & 0.30 & 23. 09 & $1.21^{-}$ & 6.20 & 5.34 & 0.46 \\
\hline & & & & 19.20 & 17.55 & 0.25 \\
\hline July 17 .. & 1.10 & 23.56 & 1.14 & 7.20 & 6.27 & 0.53 \\
\hline A verage & & 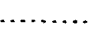 & 1.19 & & & 0.40 \\
\hline
\end{tabular}

It will be noted that the lag at high water is greater than at low, which is just the reverse of what occurs in tidal rivers, where the water rises much more rapidly than it falls and the low-water lag is long and the high-water lag short. This is an important result bearing on the relation between the fluctuations of the water in wells and the oceanic tide and clearly refutes the doctrine that the tidal fluctuations here are due to leakage and that the fluctuations are analogous to those of tidal rivers. (See pp. 63-67.)

\section{OBSERVATIONS ON THE SCHREIBER WELL NEAR MILLBURN, N. Y.}

This well is located on the very edge of the sea marsh, about 2 miles south of Baldwin station on the Long Island Railroad (Pl. II). It is 8 inches in diameter and the total depth determined by sounding is 288.6 feet. The water will, when piped up, rise about a foot above the surface of the ground. After an unsuccessful attempt to record the fluctuations here with a Friez gage, which gave no results because of the small ampliturle of the fluctuations, the King gage used on tr a Queens County Water Company well near Hewlett was set up and the record obtained from July 17 to August 5. This record shows the most erratic fluctuations obtained on Long Island (Pl. V).

In all the other records, while there are always many factors present, certain fluctuations can be definitely ascribed to temperature, atmospheric pressure, rainfall, pumping, or transmitted tides, but here either the curves produced by several of these factors have been so superposed that the character of each is thoroughly masked or new factors have been introduced. The most evidert characteristic of these curves is the greater rapidity and abruptness in the fall of the water than in its rise. Abrupt drops of this character are known to be produced by changes in barometric pressure and by pumping. It will be noted in this case that these fluctuations are not represented in the barograph curve, and a comparison with the record from the 504-foot well at Lynbrook (Pl. VI), in which the geologic conditions are very similar, shows no correspondence, although the Lynbrook well is clearly greatly affected by barometric changes.

The nearest pumping stations are at Rockville Center and Freeport, and these are small village plants. At Rockville Center there were at this time four 8-inch wells, about 50 feet deep, and at Freeport 4 wells, about 35 feet deep. At Rockville Center about 150,000 gallons per day were pumper, and at Freeport about 100,000. These 
stations are, respectively, 1.9 and 2.4 miles from the Schreiber well (Pl. II). The Rockville Center pumping station is, moreover, nearer the deep Lynbrook well than the Schreiber well, and the Lynbrook well shows no such fluctuations. It is therefore believed that these fluctuations are not due to pumping.

A third hypothesis is that the fluctuations are largely tidal, and that they represent the complicated stresses resulting from the culmination of the tides at different times in the neighboring network of creeks and channels. The conditions near this well are regarded as quite favorahle for complex tides, but the resultant of these would be represented by a smooth curve, as is shown by the Long Beach well. Th? normal tidal curve in such narrow channels would, moreover, show a rapid rise and a gradual fall, while the well curve is just the reverse.

The fluctuations in this well are, so far as known, unique. The geologic conditions are believed to correspond in a general way with those in the 368 -foot well at Long Beach and the 504-foot well at Lynbrook, both in the same region, but the characteristics of the curves are entirely different and apparently not related to either.

OBSERVATIONS AT LYNBROOK, N. Y.

A station was established one-half mile west of Lynbrook (Pl. II). At this point there were two test wells, one 504 feet deep and the other 72 feet, belonging to the Queens County Water Company. Through the kindness of Mr. Franklin B. Lord, president, and Mr. Charles R. Bettes, chief engineer, these wells were covered with a shelter, and a third well, 14 feet deep, driven about 6 feet from the other two. This gave a shallow surface well, a "deep well" (comparable to many of th ose used at the Brooklyn waterworks pumping stations west of this point) which flowed at the surface for about half the time, and a very deep artesian well, all within a few feet of each other and away from the zone of influence of any pumping station.

About 15 feet from the wells there is a small ground-water fed brook, the 1 ttom of which has an elevation of about 10 feet above sea level; the ground at the wells is 11.3 feet above sea level, and the crest of the low swell, 1,000 feet to the wert, about 20 feet (Pl. II, p. 16). The surface material is yellow loam, ranging frcm a few inches to 3 feet thick, then rather coarse sand and gravel. No record was preserved of the strata penetrated in the 72- and 504-foot wells, but a new well sunk d iring the summer of 1904, about 300 feet west of this group of wells, gave the followin $\underline{\text { section: }}$

Section of well of Queens County Water Company, one-half mile west of Lynbrook, N. Y.

Tisbury:

Feet.

1. Coarse yellow quartz sand; no erratic material. .............. $0-29$

2. Light-gray sand ..................................... $29-31$

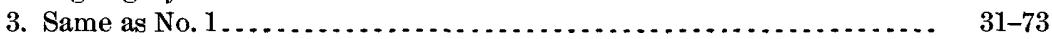

Cretaceous?:

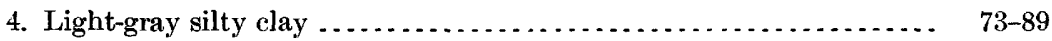

5. Light-yellow medium sand; no erratic material ............. $89-150$ Cretaceous:

6. Fine to medium gray lignitic sand . . . . . . . . . . . . . . . . $150-158$

7. Very fine black micaceous lignitiferous silt .................. 158-200

8-9. Very fine dark-colored lignitiferous sand . . . . . . . . . . . . . . . . . 200-228

10. Medium light-gray sand, with small amount of lignite. . . . . . . . 228-340

11. Dark-colored lignitiferous silty clay ...................... 340-363

12. Medium dirty-yellow sand, lignitic ....................... 363-403

13. Medium to coarse gray sand .......................... 403-536

The water in the 504-foot well, during the time of observation, stood from 0.8 foot to 2.2 feet above the surface; in the 72 -foot well from 0.6 foot below to 0.5 foot above the surface, and in the 14-foot well from 0.6 foot below to 0.2 foot abovi the sur- 
face. The water in the 14-foot well rose above the surface three or four times for seriods of a few hours. The elevation of the water table under tha low swell to the west was probably about 13 feet.

Mr. Francis L. Whitney was placed in charge of the observations at this point, and King gages were installed on supports clamped to the well casings. The gages were maintained from June 25 to September 15, and some of the results are given in Pl. VI. These give a large amount of important material bearing $r$ ot only on purely scientific problems, but on some of the live economic problems of the region. It will be noticed that as a whole the curves of these wells are parallel. This bears very directly on the old question of the source of the water in the de?p wells on Long Island. It has long been a favorite hypothesis that in some mysterious way large quantities of water were introduced by great underground strearns from the New England States, and this 504-foot well was one of the wells which were supposed to strike one of these streams. It has already been shown $a$ that the source of the water in the deep wells on Long Island is from the rain that falls on the surface (see p. 10), and the really remarkable agreement of the general shape of thes? curves furnishes additional confirmation, pointing as it does to close interrelation and a common source.

The behavior of these wells during rain storms shows that rain may affect the water level in wells in two ways, (1) without the water reaching the ground-water table, and (2) by actual infiltration and addition to the ground water. In both cases the effect is greatest in the shallow well. In the first case all wells commence to rise as soon as the rain begins, and rise abruptly, sometimes several inches. That this can not be due to actual infiltration is shown by its instantaneous character and by the fact that the water in the shallow 14-foot well, driven entirely in sand, rose above the surface of the ground four times under such circumstances. Such rises, moreover, produce no permanent deflection of the well curve. (See record for Aug. 18-22, Pl. VI.)

This sudden rise is due to a number of factors. In the first plare, when the soil above the water table is filled with air the addition of water to the surface practically seals the outlets for the air and the weight of the rain is transnitted by this confined air to the water table. The effect of such a transinissicn is to hasten the discharge of the water at the ground-water outlet, and so produce an immediate rise in the streams. In this manner rains which never reach the ground-water table and which do not contribute directly to stream flow may immediately produce a greatly increased stream discharge. It should be noted in this ccnnection that the well always rose before the adjacent brook, although the brook mimht later reach a higher elevation.

In the second case, when the water in the wells is elevated by the actual percolation of water, the water rises gradually and reaches its highest point several days or weeks after the rain, rather than in several minutes. In the case of the heavy rains which occurred on August 28, the 14-foot well reached its highest point before noon on the 29 th, the 72 -foot well at about 6 o' clock on the 29 th, and the 504-foot well at noon on the 30th. There are three factors concerned in this last rise: (1) The instantaneous transmission of pressure due to welght of rain on the surface in the vicinity of the well; (2) actual percolation in the vicinity of the well, and (3) progressive deformations resulting from the weight of the rain at more distant points. The rise in the deeper wells is wholly due to the first and third ce.uses. The curve in this case is actually displaced and returns to its former position only gradually, instead of at once, as in the case described above.

Barometric changes affect the 504 -foot well most, but are occasicnally perceptible in the 72 -foot well. Temperature changes produce rhythmical daily fluctuations in the 14- and 72-foot wells; in the first the changes are very pronounced, amounting 
to as much as $1 \frac{1}{2}$ inches a day. The 504 -foot well showed a regular fluctuation with two high and two low waters a day. The fluctuation, however, is not progressive, and so is not tidal.

The curve from the 504-foot well shows a great number of minor periodin oscillations, but the time scale is not sufficiently great to study them satisfactorily. The most pronounced of the series has a period of ahout forty minutes. The 72-foot well occasionally shows well-marked secondary oscillations, with a period of approximately eighty minutes. For a careful study of these, however, a much larger gage with a large time scale is demanded.

OBSERVATIONS AT DOUGLASTON, N. Y.

In the winter of 1902 and 1903 a number of shallow wells were sunk along the base of hills, east of Alley Creek, and near "The Alley," an old settlement just south of Douglaston, N. Y. (Pl. VII), for the Citizens' Water Supply Company. Six of these are flowing wells, and in the other two the water comes very near the surface. Through the kindness of Mr. Cord Meyer and his son, Mr. J. Edward Meyer, president and superintendent, respectively, of the Citizens' Water Supply Company, the flowing wells were piped up beyond the limit of flow and thus prepared for gaging.

The relative elevation, depth, and head in these wells are shown in the following table:

Elevations in wells of Citizens' Water Supply Company, at Douglaston, N. Y.

\begin{tabular}{|c|c|c|c|}
\hline & $\begin{array}{c}\text { Elevation } \\
\text { of surface } \\
\text { above sea } \\
\text { level. }\end{array}$ & $\begin{array}{c}\text { Depth of } \\
\text { bottom of } \\
\text { pipe below } \\
\text { sea level. }\end{array}$ & \begin{tabular}{|} 
Average \\
height \\
above sea \\
level to \\
which \\
water will \\
rise if \\
piped up.
\end{tabular} \\
\hline Alley Pond & $\begin{array}{l}\text { Feet. } \\
\quad 17.2\end{array}$ & Feet. & Feet. \\
\hline Well No. $1, \ldots \ldots \ldots \ldots \ldots \ldots \ldots \ldots \ldots$ & 20.2 & 20.5 & 19 \\
\hline Well No. $2 . \ldots \ldots \ldots \ldots \ldots \ldots$. & 10.2 & 25 & 9 \\
\hline Well No. 3 .......................... & 5 & 28 & 8.5 \\
\hline Well No. 4 ............................. & 5 & 25 & 18 \\
\hline Well No. 5 ........................ & 10.8 & 39 & 18 \\
\hline 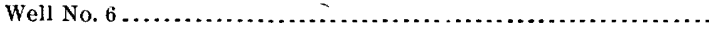 & 10.1 & 35 & 19 \\
\hline Well No. $7 \ldots \ldots \ldots \ldots \ldots \ldots \ldots \ldots \ldots \ldots \ldots \ldots \ldots \ldots \ldots \ldots \ldots \ldots \ldots \ldots \ldots$ & 9.8 & 30 & 17 \\
\hline Well No. $8 \ldots \ldots \ldots \ldots \ldots \ldots \ldots \ldots \ldots \ldots \ldots \ldots \ldots \ldots \ldots \ldots \ldots \ldots$ & 10.5 & 17 & 15 \\
\hline
\end{tabular}

The strata encountered vary considerably; some of the wells penetrate nothing but sand and gravel, and in others clay beds of greater or less thickness are found. The water is derived from the adjacent hill mass, the height of the ground water in which determines the head in these wells.

The tidal marsh to the west is a mass of soft black mud largely covered with a mat of growing vegetable matter, which is sufficiently firm to walk on, but which gives at every step. This surface mat of roots is often sufficiently tenacious to hold up when undermined by the small streams formed by the many springs that occur at the base of the hills, and these streams often flow through underground passages beneath the turf. The underlying mud or black ooze is over 10 feet thick in the uppor end of the mud flat, and Mr. D. L. Van Nostrand states that, in driving piles for a dock at the bridge, the depth to "solid ground" was found to be 65 or 70 feet. The artesian pressure beneath this mud has caused the ground to rise in several plares, with the resultant production of many small rapids (PI. VII). At a number of points near the upper end of the basin, where the mud is thin, the water has broken 
through and produced low mud cones or mud volcanoes. ${ }^{t}$ The drilling of the artesian wells and the fact that they were allowed to flow freely have perhaps in part relieved the pressure here, and during the three months the cones were observed they did not change materially, although on several occasions mid was seen rising from the craters and flowing down the sides. Three hundred feet north of the mud flat and on the east bank of Alley Creek there is a lesser area of mud which is not covered at low tide. In this there is a marked mud flow, which is likewise probably connected with the artesian waters under discussion.

Mr. Francis L. Whitney was placed in charge of the work here, and he prepared wooden shelter boxes covered with tarred paper. These were securely clamped to the top of the well pipes, which were steadied by means of guy lines. $b$ A tide gage was established on the end of the crib of the drawbridge on th ? main turnpike. (PI. VII.). The crib furnished a very good still box, and the locality is as near the wells as it was possible to get, for to the south the creek bed is uncovered at low tide.

The equipment consisted of 3 Friez gages and 1 Mead gage. The Mead gage was placed on well No. 8 and furnished the only record running through the whole of the time of observation. One of the Friez gages was p'reed at the drawbridge during the whole period, but from one cause and another no record was obtained before August 6, and after that time the record was not complete. By shifting the remaining gages records were obtained for a time from all the wells but No. 3. Some of the curves obtained from these observations are shown in Pl. VIII.

All these wells are clearly tidal, but when the question of the rate of propagation of tidal effect is considered many difficulties are encountered and the extreme complexity of the problem at once becomes evident. The curves, while broadly resembling each other, show many minor points of difference, which must be attributed to the varying shape of the tidal wave in the mud flat near the wills and the consequent complexity and variation of the stresses involved. Thus the records from wells 2 and 8 show that, while the relative amplitudes of the high tides agree perfectly and both show a tendency toward a double cusp at high tide, in well No. 2 the second cusp is characteristically greater, while in well No. 8 th 9 first cusp is often the greater; compare curves from July 27 to 29 . The low-tide curves also show marked differences; thus, in well No. 2 there is a continued fall until the tide turns, which it does sharply; in No. 8 there is a long period of stagnation and tl 3 curve is rounded when the rise begins. Evidently these curves are not readily conparable with the tide gage at the bridge nor with each other, for each represents the resultant of a different set of forces. The conditions for the production of such differences are very favorable. The semiliquid marsh mud yields readily to all presivure changes, however slight; the liquidity of the mud varies greatly from point to point, and while the artesian water does not commonly escape through the mud covering it may, as shown by the mud cones, do so at any time, and such a point of relief would affect adjacent wells differently.

Another factor making exact time comparisons difficult is the small scale of the records and the great amount of lost motion in the Mead gage. The Mead records show unquestionable time errors of one to two hours, and for this reason the end values are more important than the initial ones of each record. Where evident errors occur in the record of the Mead gage for well No. 8 they have been corrected as far as possible, and an attempt has been made to indicate on the diagram the various details affecting the time values so far as known. For this purpose the end of each of the original record sheets has been indicated on PI. VIII.

$a$ See Prof. Paper U. S. Geol. Survey No. 46, 1906, PI. XXVII, $C$.

$b$ An illustration of the gage box on well No. 4 will be found in Prof. Paper U. S. Geol, Survey No. 44, 1906, Pl. XIV. 


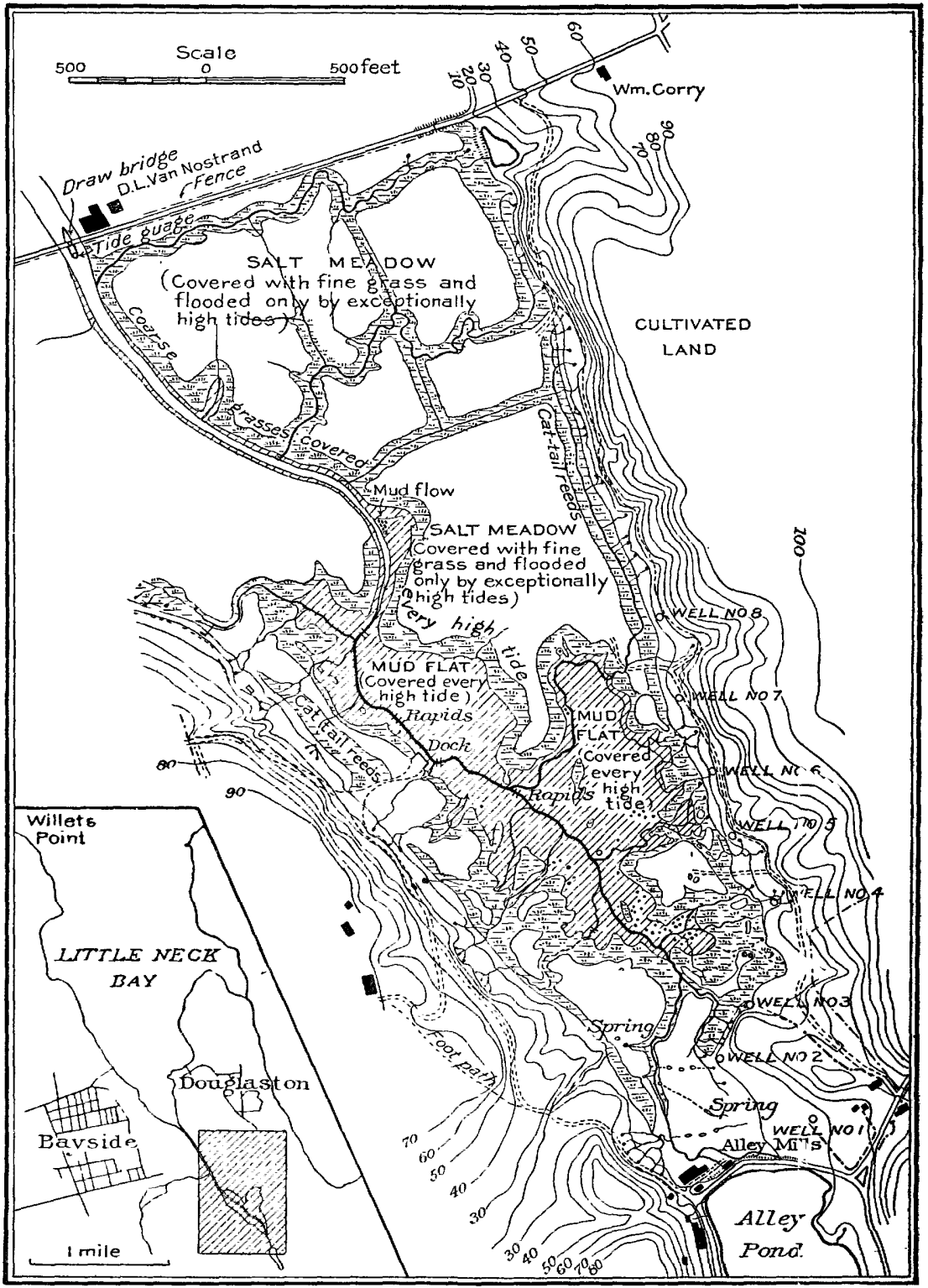

SKETCH MAP SHOWING LOCATION AND TOPOGRAPHIC SURROUNDINGS OF WELLS OF CITIZENS' WATER SUPPLY COMPANY NEAR DOUGLASTON, N. Y,

Black dots indicate bcation of mud volcanoes. By A. C. Veatch, 1903. 


\section{OBSERVATIONS OF THE NEW YORK CITY COMMISSION ON \\ ADDITIONAL WATER SUPPLY. $a$}

The Long Island division of the commission on additional water supply under the direction of Mr. W. E. Spear, division engineer, during the period from the middle of April to the last of October, 1903, made many observations on the water level in wells on Long Island. In all about 1,200 wells were observed at intervals of from one to three days by means of steel tapes fitted with cup sounders. From these observations Mr. Spear endeavored to obtain the velocity of the downward capillary flow of the water on Long Island.

Meteorological stations, equipped with self-recording instruments, were established at Brentwood and Floral Park (Pl. I, p. 9). It was from these records that the thermograph, barograph, and rainfall curves shown on Pls. III, V, and VI were obtained.

Mr. Spear likewise obtained from the records of the Brooklyn waterwo-ks data regarding the fluctuations of the water in shallow wells on the south shore and the effect of pumping at Merrick and Agawam.

$a$ Spear, Walter E., Long Island sources: Rept. Commission on Additional Water Supply for the City of New York, Nov. 30, 1903, New York, 1904, appendix 7, pp. 617-806 


\section{PART II.}

\section{GENERAL DISCUSSION OF THE FLUCTUATIONS OF WATER LEVEL IN WELLS.}

\section{CLASSIFICATION OF CAUSES.}

The vertical fluctuations of the ground-water table or the changes in the level of the water in wells may he grouped as follows:

A. Fluctuations due to natural causes.

I. Rainfall and evaporation.

1. Fluctuations not depending on single showers.

a. Regular annual fluctuations.

b. Irregular secular changes.

2. Fluctuations produced by single showers.

a. By transmission of pressure without any actual addition to the ground water.

b. By the actual addition of rain to the ground water.

II. Barometric changes.

III. Thermometric changes.

1. Fluctuation directly related to temperature.

2. Fluctuation inversely related to temperature.

a. At the surface of the ground-water table, directly through temperature changes.

b. In deeper zones, by pressure changes produced by fluctuations of the preceding class.

IV. Fluctuations produced by adjacent bodies of surface water: Rivers, lakes, the ocean.

1. By changes in rate of ground-water discharge.

2. By seepage.

3. By plastic deformation due to varying loads.

V. Fluctuations due to geologic changes.

B. Fluctuations due to human agencies.

1. Settlement, deforestation, cultivation, drainage.

2. Irrigation.

3. Dams.

4. Underground water-supply developments.

5. Unequal loading.

C. Fluctuations due to indeterminate causes.

The relation between the fluctuations due to natural causes may be stated in this way: On the broad and irregular curves produced by the seculer climatic and geologic changes are superposed the regular annual fluctuations, which are perhaps the most characteristic and important of the ground-water fluctuations due to natural causes; and on these, in turn, are superposed the simple rainfall, barometric, thermometric, tillal, and flood fluctuations. This complex curve, made up of many regular and irregular elements, is further modified by human agencies. The cumulative effect of these human agencies is irregular and the result is to modify-indeed, often to largely alter-the character of the broad irregular curves produced by secular climatic and geologic changes. Yet some of these human molifications have a periodic value which, in the case of cultivation, for example, may greatly change the amplitude of the annual fluctuations, or, in the case of pumping or the change of water level behind a milldan, may give rise to rather regular daily fluctuations. 
FLUCTUATIONS PRODUCED BY NATURAL CAUSES.

RAINFALL AND EVAPORATION.

REGULAR ANNUAL FLUCTUATIONS.

gengral Character and CaUse.

Woldřich, from a study of nine years' observations on a 19-foot well at Salzburg, concluded that the rise and fall of the ground water stands in no relation whatever to the

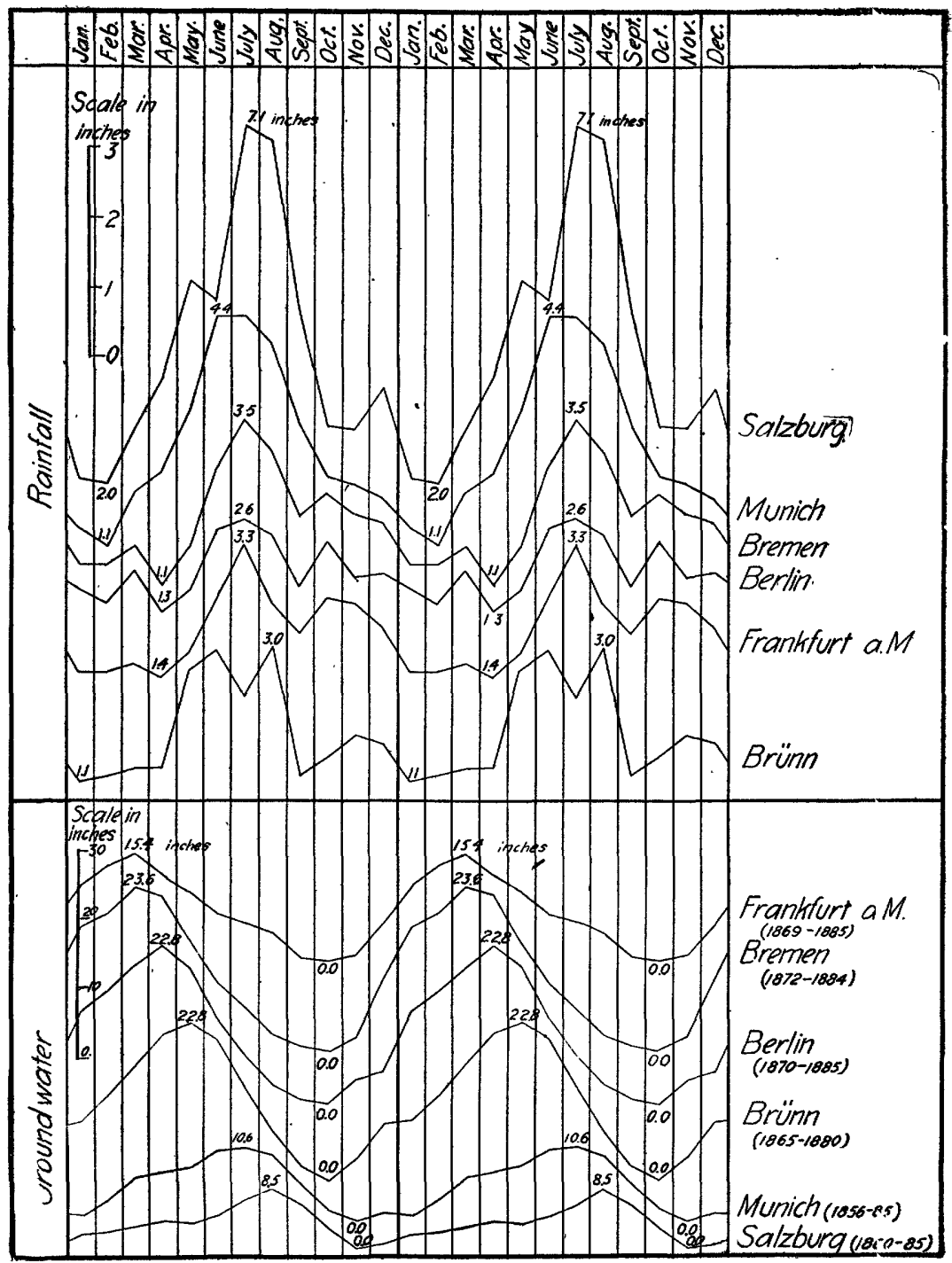

FiG. 9.-Yearly ranfall and water-level curves in shallow wells in middle Europe (afte- Soyka). The curves are duplicated for a second year to facilitate comparisons.

amount of rain, since with the same quantity of precipitation it at times rises, ard again falls, and even with considerably increasing quantities of rain it often falls constantly. $a$

$a$ Woldr̆ch-Johann Nepomuk, Mitt, d. Techn, Klubs zu Salzburg, 1869, Heft 1, Zeitschrift d. Österrelchischen Gesellschaft túr Meteorologie, Bd. 4, 1869, pp. 273-279 Penck's Geographische Abhandlungen, Bd. 2, Heft 3. Wien, 1888, p. 23. 
While so broad a statement is not entirely true for all localities in the North Tem perate Zone, yet it properly emphasizes the fact that the relation between the ground-water fluctuations and the rainfall is not the simple one which might be inferred from the statement that the rainfall is the source of the ground water. Observations at many points in the North Temperate Zone have shown that the

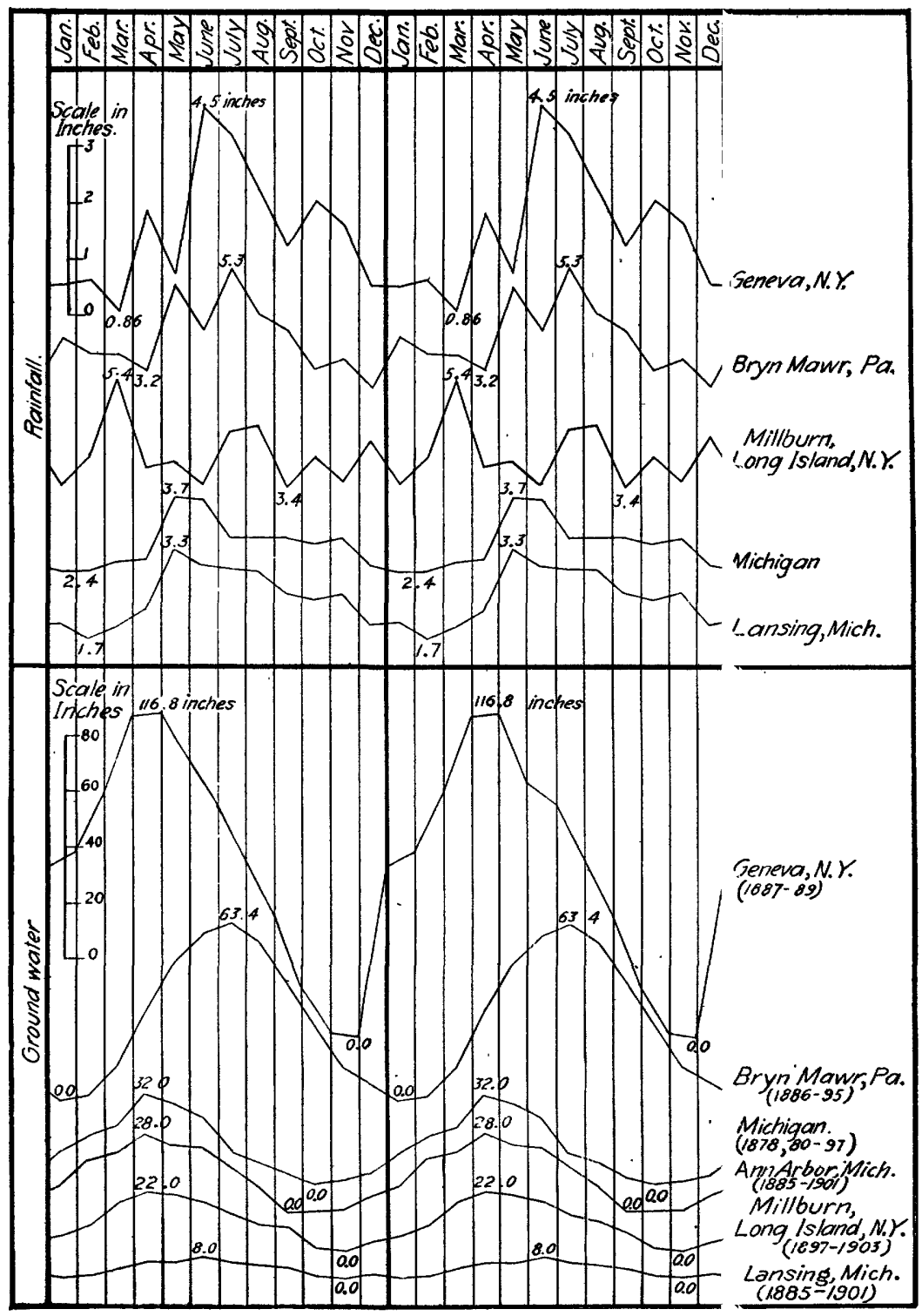

Frg. 10.-Yearly rainfall and water-level curves in shallow wells in the Unitid States. The curves are duplicated for a second year to facilitate comparisons.

ground water fluctuates in a yearly period with a single maximum and minimum, and that this curve generally does not correspond with the rainfall curve (figs. 9, 10). Indeed, at Frankfurt, Bremen, Berlin, and Brünn, the highest point of the ground water is in the spring months at the time of least rainfall (fix. 9). The yearly 
curves of the ground water are much more regular than the rainfall curve, and on the whole in general shape they most resemble the annual temperature crirve (fig. 11). The reason for this difference is the simple one that the fluctuations of the ground water depend not only on the absolute amount of the rainfall, bit, on the quantity that reaches the zone of complete saturation, or the ground-water table, and the time consumed in so doing. The quantity is affected by many factors, among which are the evaporation from the surface of the ground, the evaporation or transpiration from plants, the quantity retained in the soil above the zon of saturation, and the amount that runs directly off the surface without ever peretrating the ground. The time element is affected by the porosity and moisture content of the soil, the character of the covering, and to a greater or less extent by $\mathrm{tl}$ s height of the soil column. The general result is that the water is delivered gradually to the zone of complete saturation, and as the effects of single rains are thus generally

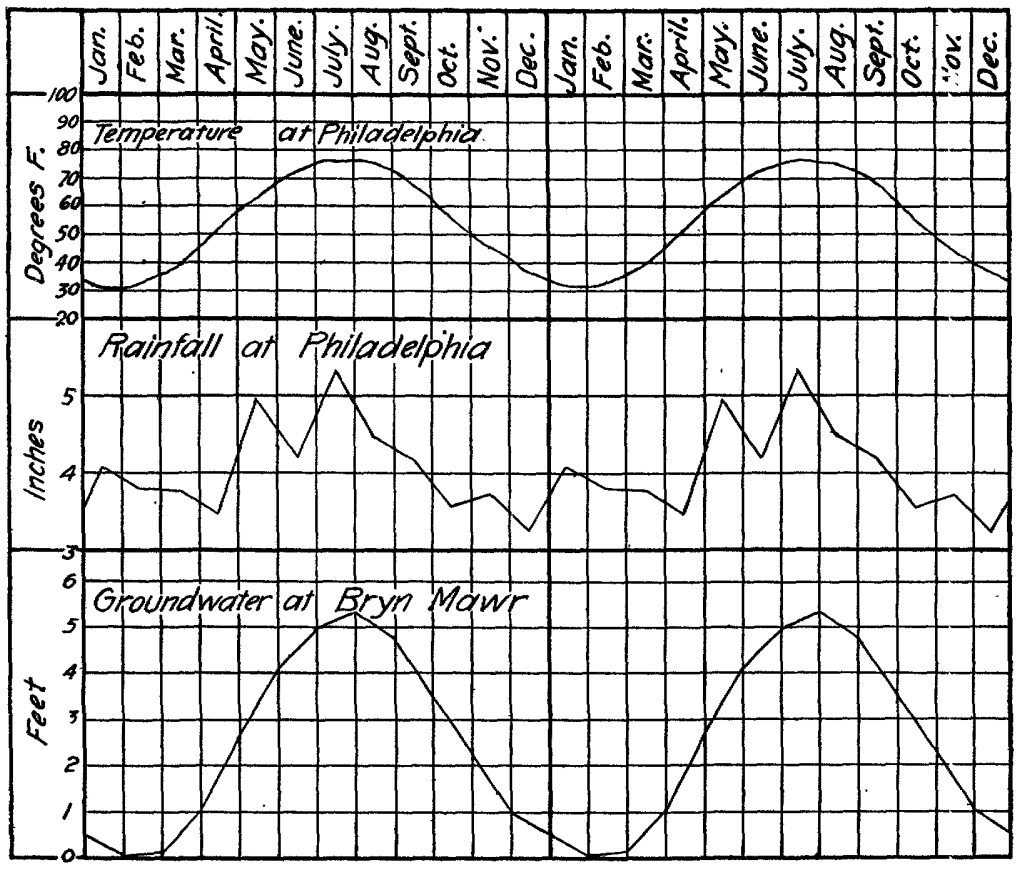

FIG. 11.-Annual curves based upon mean monthly averages of ground-water level $\varepsilon t$ Bryn Mawr, Pa., $\alpha$ and temperature and rainfall at Philadelphia, Pa., $b$ for the period 1886-1895, showing the general resemblance of the ground-water and temperature curver. The exact agreement of the maximum ground-water level and the maximum tempereture is unusual.

minified and often entirely blotted out, a relatively smooth curve results ( $\mathrm{Pl}$. IX). This yearly period of the ground water is largely due to the periodic character of the evaporation, including plant transpiration. This depends on the temperature, and the net result for the year is a simple curve of the same shape as the mean temperature curve, although inversely related to it, hence the general resemblance of the yearly well curve to the temperature curve. Were the rain uniform throughout the year, and were there no lag due to transmission or unmelted snow, the maximum ground-water level would occur at the time of the minimum temperature and saturation deficit of the atmosphere, or, in the North Temperate Zone, in January. The effect of the irregular distribution of the rainfall is to change the time of the occurrence of this maximum. A moderate excess of rain in the summer, such as occurs 
at Frankfurt-am-Main, causes the maximum to advance to March, while at Bremen, Berlin, and Brünn, where the difference between the summer and winter rainfall is progressively greater, in the order named, the maxima occur respectively in March, April, and May (fig. 9). The extremely great summer precipitation at Munich and Salzburg, together with the low rainfall in January, causes the maximum at those places to advance to July and August.

In this connection the observations of (1) Dickinson and Evans, (2) Greaves, and (3) Lawes and Gilbert, near Lonilon, are of great interest. All of these observers endeavored to determine the amount of rain actually contribited to the ground

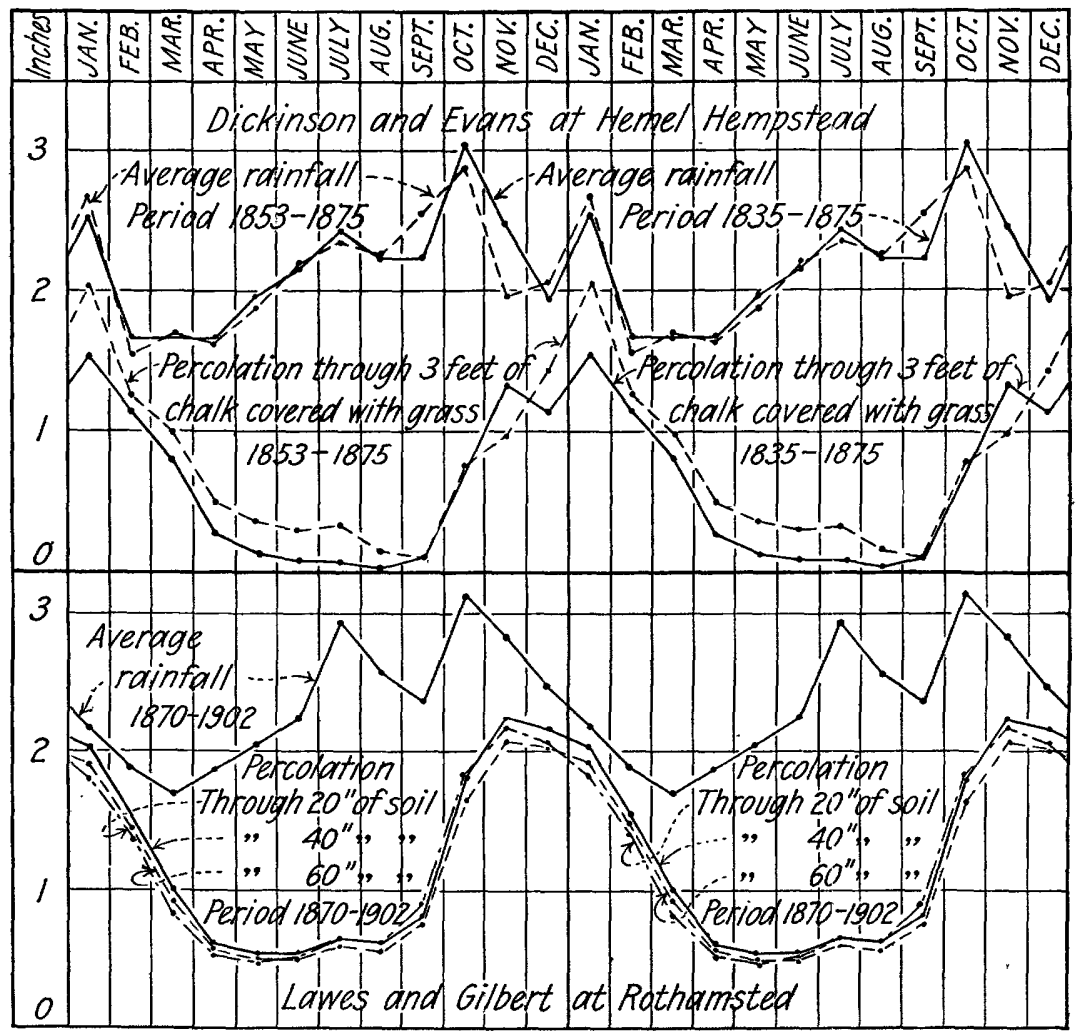

FIG. 12.-Results of English percolation experiments. In the Dickinson and Evans experiments the gages were buried in the ground; one was filled with ordinary Hertfordshire soil (a sandy, gravelly loam) and covered with sod; the other was filled with chalk and covered with a thin layer of soil and sod. In the Lawes and Gilbert observations columns of a rather heavy loam with clay subsoil in their natural state of consolidation were built in with bri-k and cement; no vegetation was allowed to grow on the gages, which were surrounded by meadow land. Curves are based on the monthly averages from September 1, 1870, to August 31, 1902.

water. Each used vessels with impervious sides and pervious bottoms, sunk level with the surface of the ground. The water percolating through the soil columns was collected and compared with the yield of the adjacent rain gages. In the case of the Dickinson and Evans and the Greaves experiments the boxes were filled with material supposed to represent the average soil of the region, in both cases a sandy loam. In the Lawes and Gilbert experiments actual blocks of soil were undermined and the results represent the amount of rainfall passing through a heavy loam with a clay subsoil in its natural condition of consolidation, but not covered with vegetation. The average results obtained are given in the following table and aro partially shown in a graphic manner in fig. 12 . 


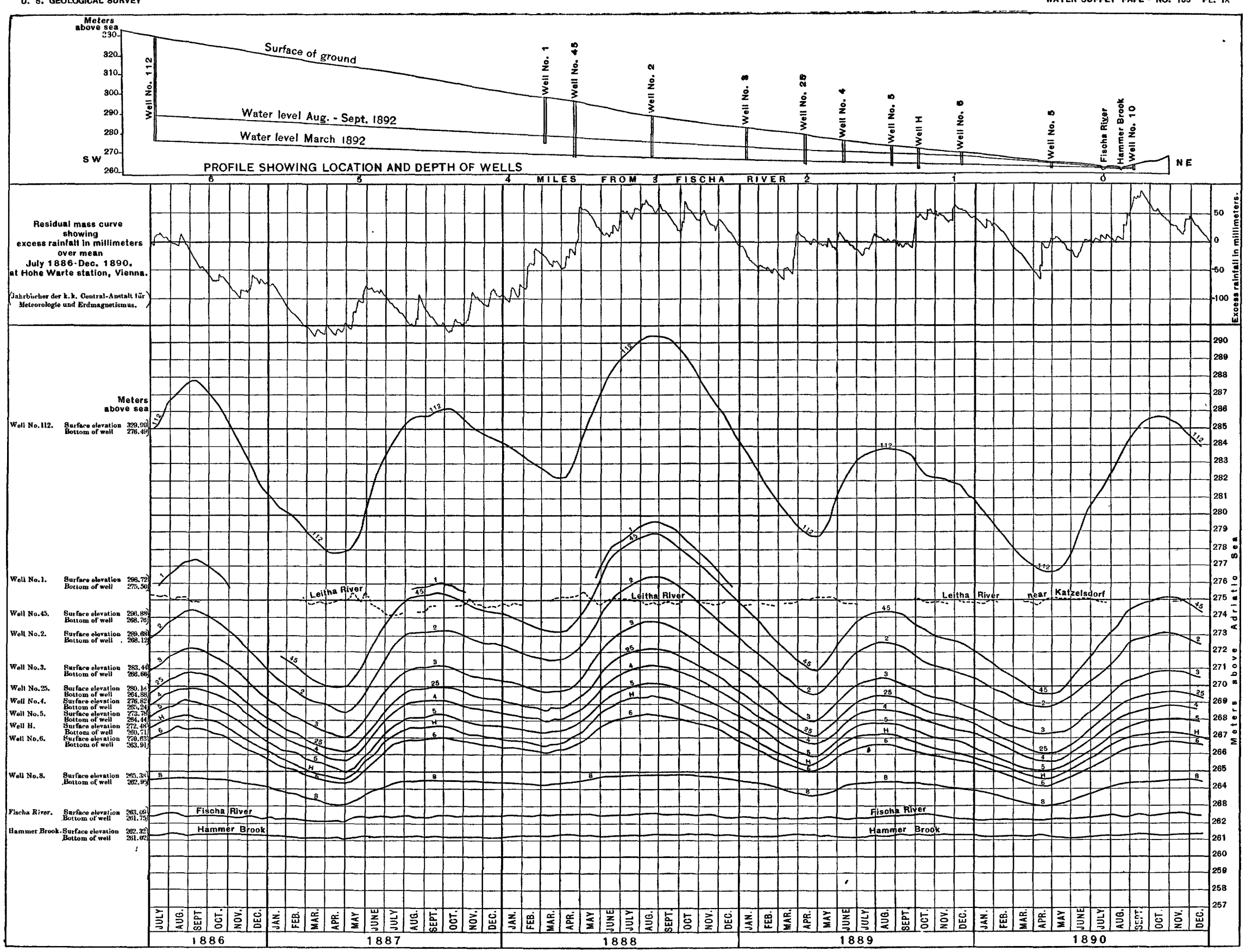

FLUCTUATIONS OF WATER LEVEL IN WELLS NEAR WIENER NEUSTADT, AUSTRIA.

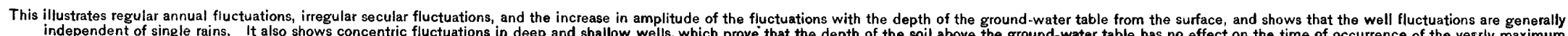

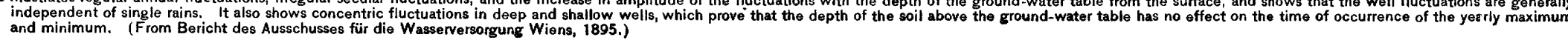




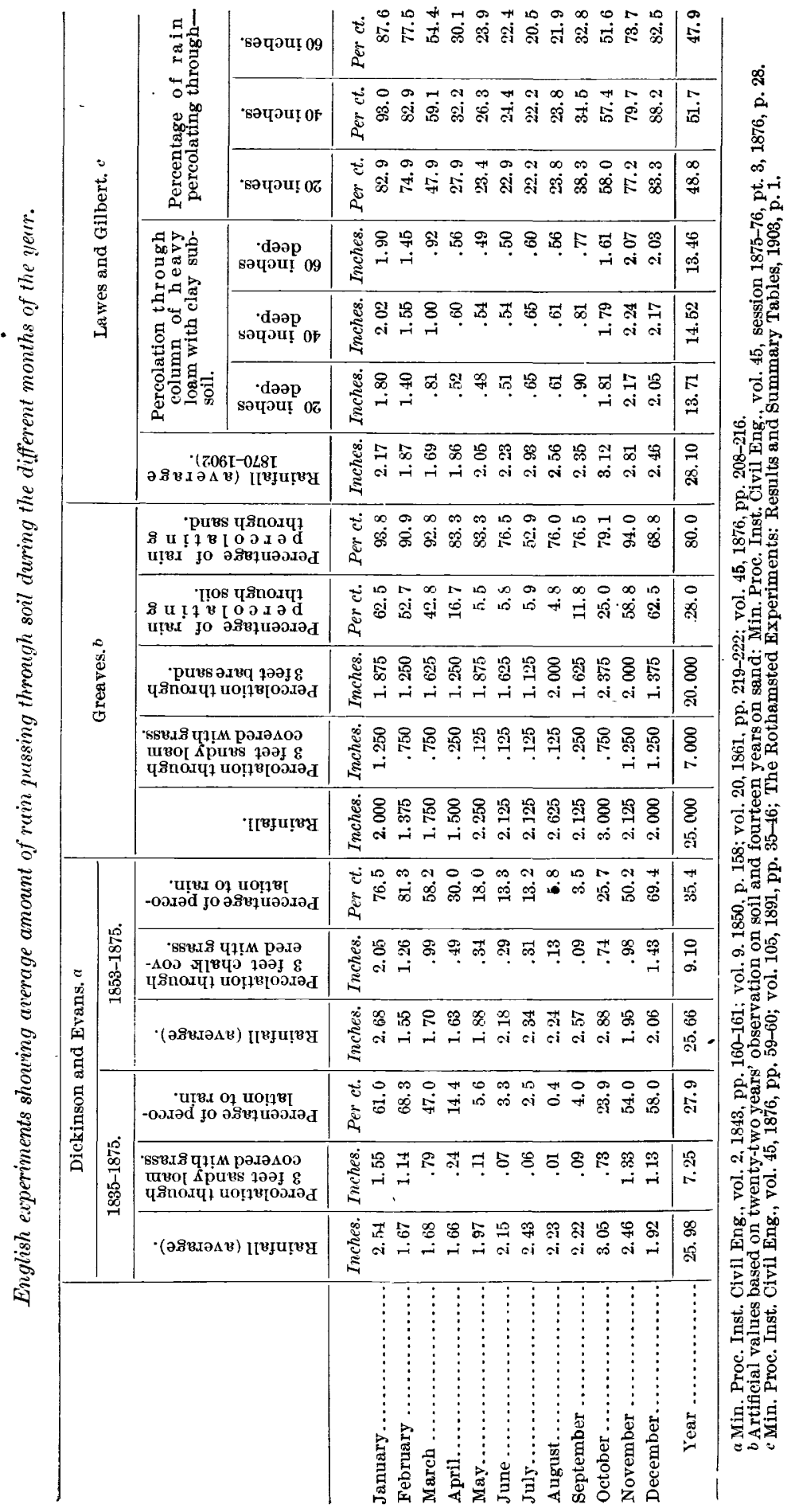


Of these the Lawes and Gilbert results are perhaps of the greatest value, because they more nearly represent the normal conditions, and they extend through a sufficiently long period to obliterate temporary variations. While th? quantitative values obtained from these experiments differ, the qualitative results, as shown by fig. 12, are essentially the same. All except the bare sand give curves of the same character as those obtained from the actual observation of ground-water flustuations. The low percentage of water which passes through the soil in summer is emphasized by all, as is also the greater contribution during the winter months. Even in the bare sand, where the water sinks at once and so loses little by evaporation. a downward tendency of the curve during the summer months is evident. The effect of the heavy precipitation in the fall is particularly evident in the Lawes and Gilbert results (fig. 12), where it clearly hastened the time of occurrence of the maximum ground-water percolation by about two months.

EFFECT OF DEPTH OF SOIL ABOVE ZONE OF COMPLETE SATURATION ON TIME OF OCCURRENCE OF YEARLY MAXIMUM AND MINIMUM OF GROUND-WATER LEVEL.

It has been suggested that the soil above the ground-water table tends to destroy the effect of single rains by causing the water to be delivered gradually to the zone of complete saturation, whose upper surface is the water table. In the case of the English experiments at Rothamsted (Lawes and Gilbert) and Hemel Hempstead (Dickinson and Evans) the maximum percolation occurs from November to January, yet the water in the wells in that region, while commencing to $\mathrm{r}^{\text {se }}$ about December, did not reach its maximum elevation until March, $a$ a delay of s.bout three months. Yet in any attempt to calculate the rate of percolation from these data two difficulties are encountered. In the first place the yearly maximum occurred at about the same time in this region in wells of all depths, and, furthermore, the Rothamsted results (fig. 12) show no very important difference in the time in which the water is discharged through 20,40 , and 60 inches of soil so far as it relates to the time of occurrence of the yearly maximum. In the second place the underground water is in motion, a certain amount is discharged at all times, and th? amount increases with the head. The case is not, therefore, the simple one where water is caught in a measuring tube, as in the percolation experiments above described, but the water must reach the ground-water table at a rate greater than the rate of the outflow, else no rise will take place.

At Wiener Neustadt, Austria, a similar relation has been demonstrated by the observations made between 1883 and 1895, in connection with tl 9 Wiener Neustadt deep-well project for the supply of Vienna. ${ }^{b}$ These wells are in a valley filling of fluvio-glacial material, somewhat irregular in character, which Suess describes as a series of old deltas. $c$ The wells extend from Fisha River, a spring-fed stream, southwesterly along the Southern Railway. The land and the ground-water table beneath both rise gradually in this direction, but while the water table is at the surface of the ground at Fisha River, $6 \frac{1}{2}$ miles south, at St. Agyden, it is from 140 to 170 feet from the surface, the exact depth depending on the time of year. (See section at top of Pl. IX.) The curves obtained from this series of wells extending roughly at right angles to the slope of the water plane, are entirely concentric, and the maximum and minimum occur at the same time, irrespective of depth of soil above the ground-water table. It would seem to follow from these data that no very satisfactory determination of the rate of downward percolation can be made from the relation of the time of greatest precipitation, or percolation, to the time of maximum

a Clutterbuck, James, Min. Proc. Inst. Civil Eng., vol. 2, 1842, p. 1566.

$b$ Bericht des Ausschusses für die Wasserversorgung Wiens: Österreichischer Ingenieur- und Architekten-Verein, 1895.

c Ibid., p. 32; see also Bericht über die Erfolge der Wiener Wasserleitungs-Commission, 1864; Karrer, F., Geologie der Franz Josephs-Quellenleitung: Abhandlungen der K.-k. geologischen Reichsanstalt, 1877. 
ground-water level. The rise of the water is not determined by the simple delivery of water to the zone of complete saturation, but by the relation of the water so delivered to the rate of outflow. If the water is lowering, a certain amount is consumed in checking that tendency, and only the excess over the outflow is available for raising the ground-water level. Moreover, in several carefully observed instances, the depth of the soil above the ground water has been shown to have no effect on the time of occurrence of the yearly maximum.

The short-period observations on Long Island, New York, during the summer of 1903, however, gave quite different results from those obtained at Wiener Neustadt. The conditions do not appear to be essentially different; the glacial sands ard gravels of the south plain of Long Island slope gradually to the ocean and in a sinuilar way the valley glacial gravels of Wiener Neustadt slope to Fisha River, and there is apparently no great difference in the irregularity and complexity of the bedding. The Wiener Neustadt or Steinfeld Valley, it is true, is traversed by a large river, the Leitha, whose stages depend on the conditions affecting its headwaters in the mountains, but observations have shown that this stream, because of the silted character of its bed, affects only a few wells in its immediate vicinity, and is not to be regarded as a disturbing factor. (Compare the river stages with well curves on Pl. IX.) On Long Island the measurements in charge of Mr. Walter E. Spear, departre ent engineer of the commission on additional water supply, ${ }^{a}$ showed that, during the summer of 1903 , the highest stage of the ground water occurred, as a rule, earlier in the shallow than in the deeper wells (fig. 13). Where the water level was less than 20 feet from the surface the highest stage of the ground water occurred in April, while where the water level was 60 to 75 feet below the surface it did not occur until A ugust. The increase of the retardation was not always uniform. Thus the highest water in a 35-foot well near Jamaica (No. 551) occurred in Mav, while in a well of the same depth near Deer Park (No. 388) it did not occur until August, although in a well near Hicksville (No. 237), of about the same depth, the maximum occurred in May. Whether this irregularity is typical or is only a result of the rather peculior season in which the measurements were made could be determined only by obsorvations covering a period of years, instead of months. It should, however, be stated in this connection that along the south shore, where the Brooklyn water department has observed shallow wells for several years, the curve for 1903 is not greatly different from that of preceding years, indicating, so far as the shallow wells are cc ncerned, that the year is not to be regarded as an abnormal one (fig. 15, p. 39). On the other hand, the results are so at variance with the thirteen years' observations at Wiener Neustadt, which apparently cover similar conditions, that further confirmation of these Long Island results, by additional observations, is needed before any conclusions can be drawn. Certainly the Wiener Neustadt data indicate that the depth of the soil above the ground-water table is of no importance in determining the time of occurrence of the maximum ground-water level. On the other hand, the Long Island observations suggest that a difference in thickness of 60 feet may delay the time of the occurrence of the maximum level four months.

The curves showing the result of the Long Island work indicate further that, in the soil in question, single showers frequently produce very definite effects in shallow wells, and that such effects become less as the depth of unsaturated material above the water table increases. Indeed, in the wells where the water is 30 or 40 feet below the ground, the curves are relatively smooth or the variations bear no evident relation to the rainfall. $b$ Spear has attempted to trace the time of rise, due to given showers, from the shallow through the deeper wells, and so determine tha rate of

a Long Island sources: Rept. New York City Commission on Additional Water Supply, 1904, appendix 7, Pl. IV, incorrectly numbered Pl. VI, p. 792.

$b$ Many of the wells observed by the commission were open, dug wells, which were in use, and the minor fluctuations are partially due to this cause, as well as to barometric and thermometric changes. 


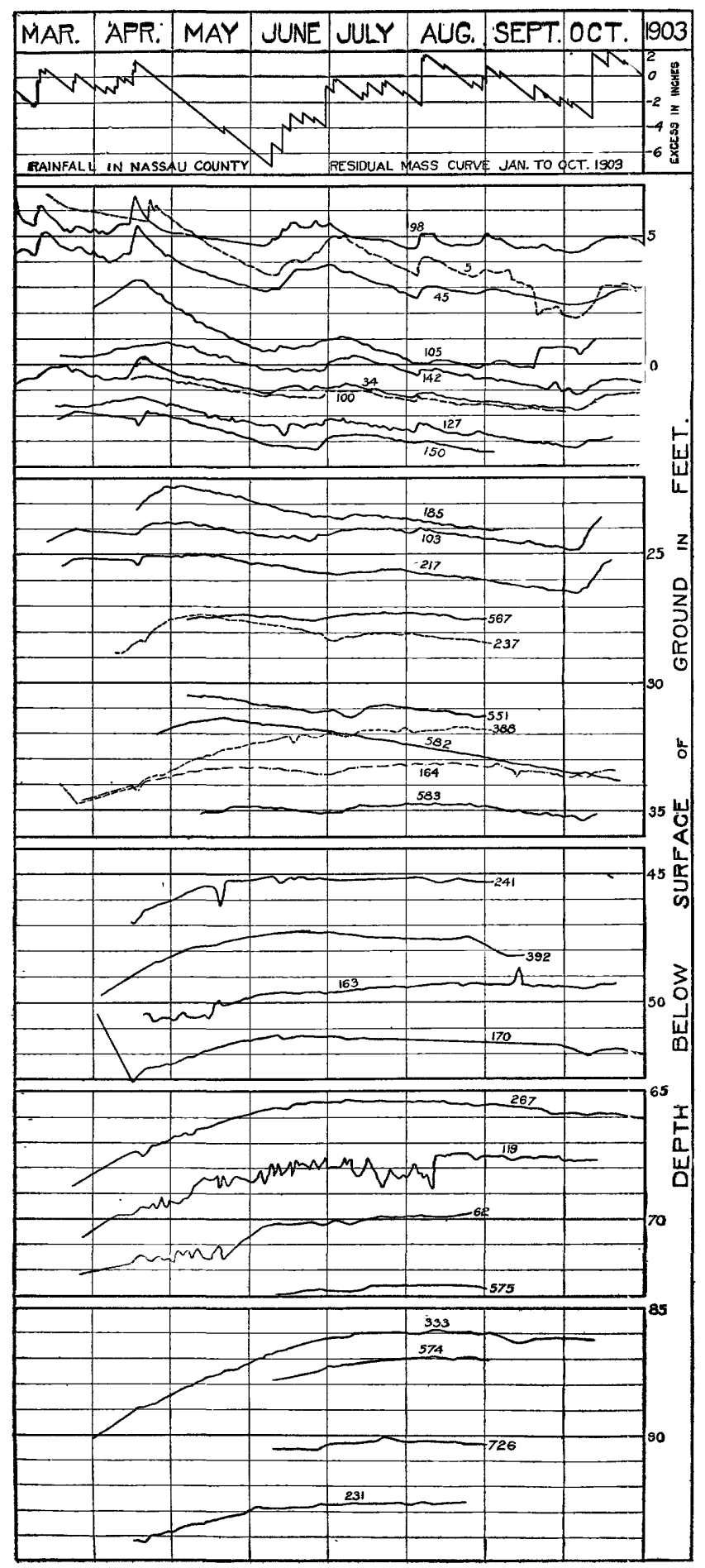

空客 弯 넝 픠

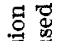
思 \$ 焉 萜 bo 要 至 兘 s कo 要哥 
downward percolation or downward capillary flow. There are certain difficulties in the way of determining the value sought in this manner. In the first place, the fluctuations in the shallow wells can not be satisfactorily correlated with those in the deep ones, and the only line which can be followed through the diagram prepared by Spear is the time of maximum ground water, which, as indicated abové, in this region during the time of observation, in general lags proportionally to $\mathrm{tl}$ a depth. This gives a fairly regular curve and the remaining curves have been inforred on either side of this one. The yearly maximum, however, can scarcely be attributed to a single rain, but represents rather the culmination of a whole series of events, and hence can not be used as a basis of such a calculation.

In the case of regions like Wiener Neustadt it is clear that the results from calculations of this character would have no meaning, and, indeed, what do the values really represent on Long Island?

\section{IRREGULAR SECULAR FLUCTUATIONS.}

The observations of Dickinson and Evans and of Lawes and Gilbert witl percolation gages developed the fact that, as a rule, not only did more water percolate in wet than in dry years, but that the percentage of rain water which passed through the soil columns was usually much greater in wet years than in dry ones. Thus while the average yearly percolation of 1870-1902 at Rothamsted (Lawes and Gilbert) was 49 per cent of the yearly rainfall of 28 inches, in the year 1878-79, when 40.2 inches of rain fell, 61 per cent of the rain water passed through a soil column 60 inches high, and in the year 1877-78, with a rainfall of 18.2 inches, the percolation was but 36 per cent (see p. 47.) The general tendency-although there are exceptional cases, such as recorded at Hemel Hempstead (Dickinson and Evans) in 1858-59, when, with a rainfall of 28 inches, 2 inches more than the annual average, the percolation was but one-third of 1 per cent instead of the usual 27 per cent-is for the small differences in the annual rainfall to have a rather magnified value in the ground-water fluctuations.

The yearly variations of the rainfall are generally progressive over rather long periods (fig. 14), and corresponding broad, irreg lar variations of the ground-water level are produced. On Long Island the shallow wells observed by the Brooklyn waterworks show, besides the annual fluctuation?, secular variations corresponding in general with those of the rainfall (fig. 15). Thus the lowest point in both curves is in 1901 and the highest in 1899. Many differences are, however, to be noted between the two curves. The annual curve, though it may be slightly modified, persistently recurs, whatever the rainfall. Note in this connection the regular downward course of the ground water in the latter part of 
1898 and 1903, when the rainfall curve is rising, and the appearance in 1900 of a typical yearly curve when the rainfall curve falls rather regularly from the spring of 1899 to 1901.

Similarly, in the Wiener Neustadt observations (Pl. IX, p. 62) the secular variations of the ground-water level broadly follow the variations of the rainfall.

The observations of Auchincloss $c$ on a well at Bryn Mawr, Pa., which have been plotted by Spear $b$ in connection with the yearly rainfall and temperature curves, likewise show pronounced annual and secular fluctuations. Here, however, the secular fluctuations of the ground water, while broadly resembling the rainfall variations, show some points of difference. Thus, the minimum of the secular curve of the ground water is in $1885-86$, while the minimum rainfall is in 18 ? shape of the two curves for $1886-87$ and 1888 is by no means parallel. The positions of the maxima, however, agree closely, and there is a general falling off in both curves from 1889 to 1893-94. Though the extreme rains of the latter part of 1889 temporarily obliterated the annual curve, it quickly reasserted itself.

In general it may be said that irregularities in the yearly curve are due to irregularities in the rainfall occurring in the same year.

\section{AMOUNT OF ANNUAL AND SECULAR FLUCTUATION.}

The size of the annual fluctuations depends principally upon (1) the percentage of rainfall reaching the ground water; (2) the amount of free pore space of the strata in the zone affected by the fluctuations, and (3) the relation of the ground-water table to the topography of the region involved.

It is relatively self-evident that, where a single well is considered, the range of the yearly fluctuations will vary with the first factor, and that in general the same amount of infiltration will produce a greater fluctuation where the pore space is small than where it is large. It does not, however, follow that in a given region, in beds of the same porosity, the same annual rainfall under the same climatic conditions will produce the same results. Observations have shown that whatever the rainfall or porosity, provided the latter be reasonably constant in the area under consideration, the annual fluctuations approach zero at the point of discharge and tend to regularly increase in magnitude from that point to the ground-water divide. $c$ Thus at Wiener Neustarlt (Pl. IX, p. 62), near the ground-water discharge into Fisha River, where the depth to the ground-water table is about 5 feet, the yes rly fluctuation is 3 to 4 feet, while at St. Agyden station, where the water plane is about 150 feet from the surface, the fluctuation is 25 to 30 feet, and the fluctuations in the intervening wells are proportional to their position between these two points. On Long Island the annual fluctuation 2 miles from the shore, at Millburn (figs. 13, 15), is 22 inches, while at the ground-water divide, 8 to 9 miles from the south shore, the fluctuation is about 10 feet. A few observations regarding the amount of the yearly fluctuation at different points have been collected in the table following. Many of these points of observation are located near the points of discharge, and the values as a whole are to be regarded as low.

In records for but a few years it is evidently impossible to separate the annual from the secular fluctuations. When, however, the observations cover a considerable period, it is possible to obtain a value for the secular fluctuation. This equals the total range less the average yearly fluctuation. A few such values are given in the table on page 40 .

- a Auchincloss, W. S., Waters within the Earth and Laws of Rainflow, Philadelphia, 1897, p. 9.

$b$ Spear, Walter E., Rept. Commission on Additional Water Supply for the C ty of New York, 1904 , afpendix 7 , fig. 45 , p. $82^{\circ}$.

The cross section trom Watford to the Chiltern Hills midway between Colne and Gade rivers, which accompanies Clutterbuck's discussion of the "Periodic A Iternations of the Chalk Water Level under London" (Min. Proc. Inst. Civil Eng., vol. 9, 1850, PI. VI), is a most excellent diagrammatic illustration of this principle. 


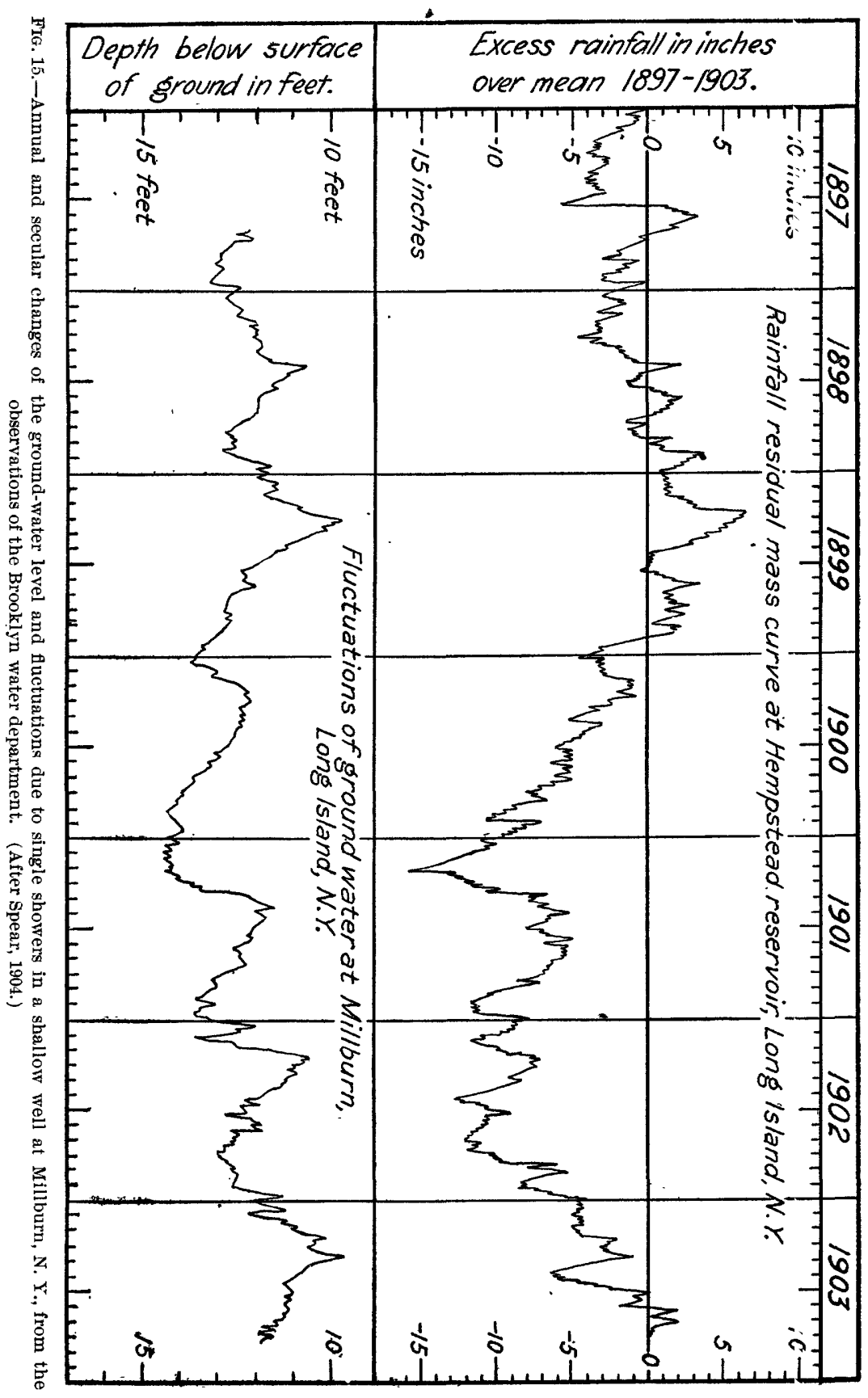




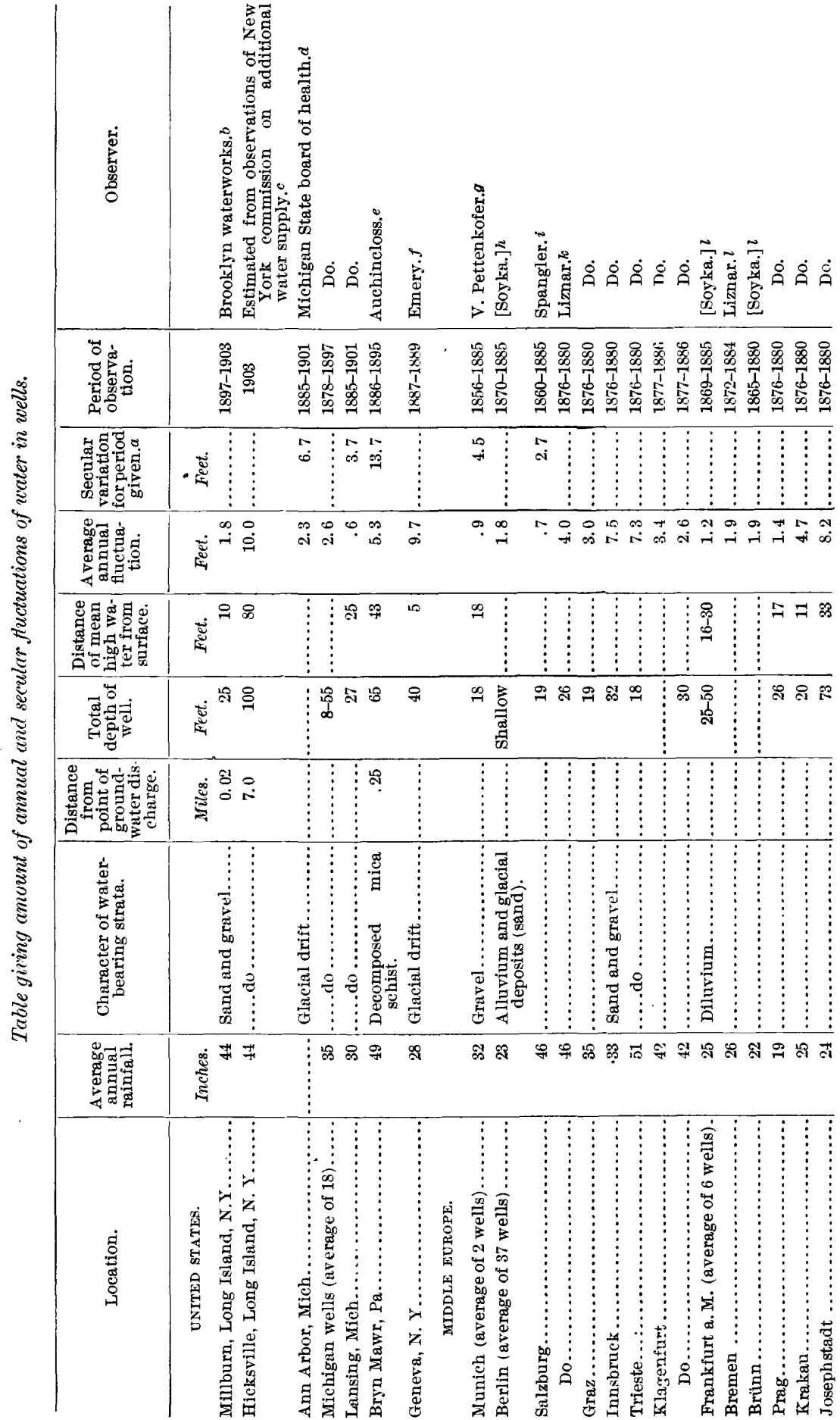




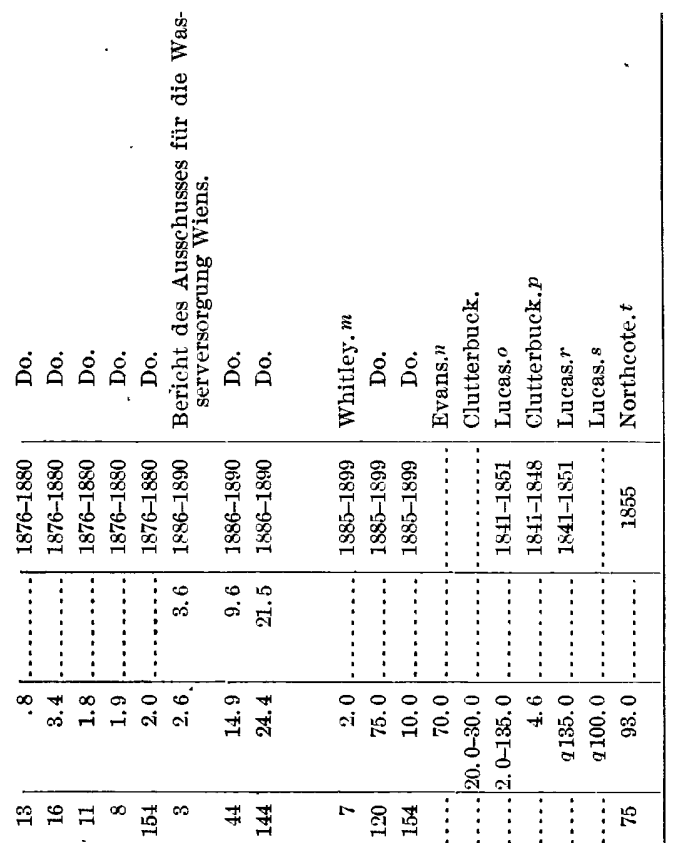

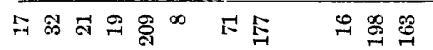

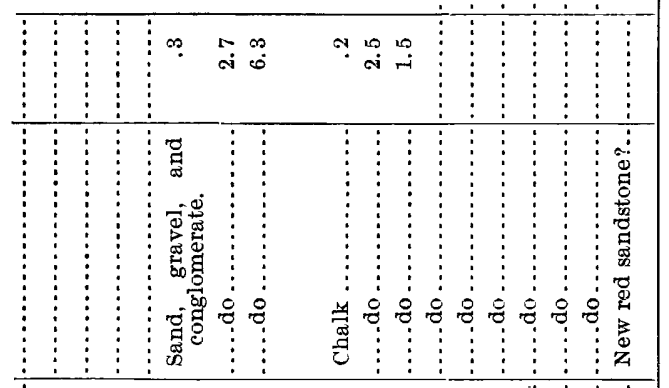

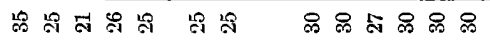
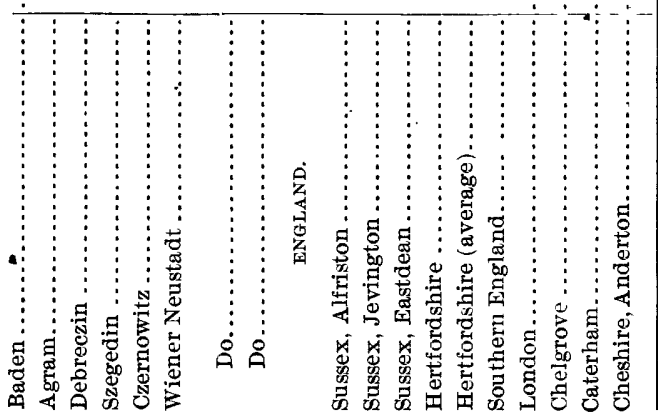

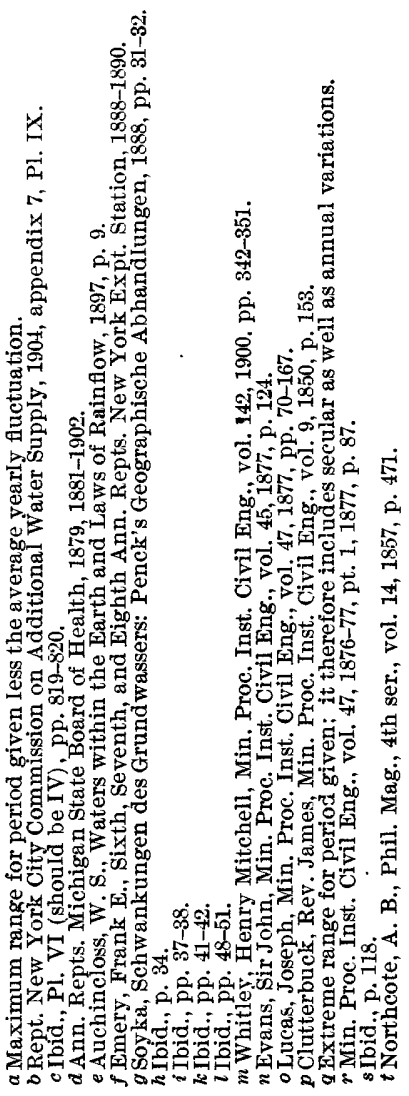


FLUCTUATIONS DUE TO SINGLE SHOWERS.

In the foregoing consideration of the relation of the rainfall to secular and annual fluctuations, the most important factor was clearly the amount of water actually contributed to the zone of complete saturation, or the ground water. $a$ In these cases the water table rises or falls because the amount of water received is greater or less than the outflow.

In the consideration of single showers, however, it is found that another factor is of as great or even greater importance. Single showers may affect the water level in a well in two ways: (1) By transmission of pressure without any actual addition to the ground water-indeed, in many cases the elevation of the water in the well is accompanied by an actual depression of the ground-water table; (2) by an actual contribution to the ground water whereby the level of the water table is raised.

FLUCTUATIONS PRODUCED BY SHOWERS BY TRANSMITTED PRESSUFE WITHOUT ANY INCREASE IN THE GROUND WATER.

King observed at Madison, Wis., $b$ that the water often rose in wells very suddenly and sharply during summer rains, when an investigation of the soil showed that it was dry beneath the surface covering wet by the showers. Similar occurrences were recorded at Lynbrook, N. Y., where in a 2 -inch well 14 feet deep every rainduring the period of observation, July 17 to September 10-was recorded and its duration and complexity indicated. Many of these fluctuations produce no permanent deflection of the ground-water curve and the evidence that no water from several of these rains reached the ground water is regarded as conclusive (Pl. VI; also note particularly the behavior of the shallow well August 10-21 and the fluctuations produced by rains of July 20,22, 30, and August 6; the two successive showers of August 6-7 are particularly noteworthy).

In the case of wells which are not separated from the main water table by impervious layers and in which the water is not under artesian pressure, this is due largely to the hydrostatic transmission of pressure by means of the soil air. When the rain strikes the surface it closes the superficial soil pores or interstices and thus confined and compresses the air in the soil between the surface and the ground-water table. The weight of the rain is thus transmitted to the ground-water table, and the extra head so developed raises the water in wells and increases tho discharge at the ground-water outlets. The effect on the stream flow is very analogous to the increase produced by a lowering of the barometric pressure. It is thus possible for a rain to produce instantly a change in the water level in wells and an increase in the groundwater outflow without contributing a drop to the ground water. This has an important bearing on the calculation of "flood flows" from ground-water-fed streams, for it is evident that in this manner a decided rise in the stream may be produced by a rain from which there is no direct run-off and which does not reach the ground-water table.

Two other factors may be involved in the production of the chenge in level during rains: (1) An actual elastic compression or plastic deformation of the soil, and (2) a change in the capillary conditions. King observed in a shallow well near a railroad track that the passage of a freight train caused a quick rise and fall of the water in the well (p. 75). Apparently the weight of the train compressed the es.rth and by decreasing the pore space caused the water to rise. The weight of the rain might have a similar effect. Under this hypothesis the water would rise on the addition of the rain and gradually fall on its removal by evaporation.

a Ground water as here used does not include the hygroscopic and capillary water above the water table, or zone of complete saturation. For the purpose of this discussion, water is not considered "ground water" until it reaches the water table.

b Bull. U. S. Weather Bureau No. 5, 1892, pp. 20, 72-73. 
Regarding the second hypothesis it is well known that changes in the surface conditions greatly affect the capillary action of the soil. At Purdue University it was found that the addition of a thin layer of soil to the surface of a lysimeter caused an immediate discharge of water. $a$ This was attributed to a change in the capillary conditions, and it has been suggested that the wetting of the ground surfase would produce a similar effect. King, however, observed $b$ that a moderate wetting of the surface tended to increase the upward percolation, and the effect of wetting the surface at Lynbrook would therefore be to diminish rather than increase the rise due to rains which do not contribute to the ground water.

At the Colorado experiment station Headden has observed $c$ that light rains during dry periods produce a comparatively great increase in the height of the water plane, while in intervals of abundant moisture, when the soil is wet, rains of this character do not produce such an increase; moderate rains are here sometimes accompanied by temporary depressions of the water plane. These observations may be explained on the basis that the soil air is the principal factor and that when the soil is very moist there is so little soil air that no effect is possible with slight showers. The cause of the temporary depression after moderate rains is not evident unless the conditions are unfavorable for the transmission of pressure by the soil air, but are such that the increased upward capillary action resulting from the moistening of the surface is sufficient to perceptibly decrease the ground water.

Where there is an impervious layer between the water-bearing strata and the local ground-water surface, and where there is artesian pressure, the added weight due to the rainfall in all cases acts directly. In case the rain is uniform oror a considerable area this pressure may be regarded as acting on an elastic body and the same character of results is to be expected in both deep and shallow wells. Thus in the Lynbrook wells on July 22 and August 25 all wells show a sharp vertical rise (Pl. VI). On July 22 the rise started in the 14 -foot well at $10 \mathrm{p} . \mathrm{m}$., in the 72 -foot well at 10.25, and in the 504-foot well at 10.34; on August 25 a somewhat similar lag is noted, the 14 -foot well rising at $4.10 \mathrm{p}$. m., the 72 -foot well at 4.20 , and the $504-$ foot well at 4.24. The cause of this lag is not fully apparent. With a direct transnission of pressure such as the curve indicates no lag is to be expected. It may be that in this case the soil is to be regarded as having some of the plastic characters shown in other cases.

On the other hand, when the rainfall is unequally distributed in time and amount a plastic deformation may result, due to unequal loading, which will gire rise to different results in wells of different depths. In the shallow well the zone of influence is relatively limited and the condition in this area may be regarded as fairly uniform. The result is therefore immediate and abrupt, as in the first case. In the deeper wells, however, the increasing zones of influence bring in more factors, which, arriving progressively from different sources, tend to produce a more and more gradual change. Thus, in the Lynbrook wells there were on August 6-7, 11, and 20 abrupt changes in the 14-foot well and a more gradual one in the 72-and 504-foot wells.

This plastic deformation in the surficial beds, produced by varying load and the response of the water to it, throws some light on the extreme complexity of the fluctuation recorded in the wells, for it suggests that variation in load, from whatever cause, will produce corresponding fluctuations. The water level in deep wells where an artesian head is developed may thus be very sensitive to local conditions, the effect of local rainfall and of the yearly fluctuations of the local ground-water level being felt to a greater or less degree by transmitted pressure in the deepen zones.

a Second Ann. Rept. Indiana Expt. Station, 1889-90, pp. 32-33.

$b$ Seventh Ann. Rept. Wisconsin Agric. Expt. Station, 1890, p. 135.

$c$ Headden, William P., A soil study, pt. 4, The ground water: Bull. Colorado Agric. Erot. Station No. 72, 1902 . 
FLUCTUATION OF THE GROUND-WATER LEVEL RESULTING FROM SINGLE SHOWERS, BY ACTUAL PERColation.

The fluctuations produced by direct percolation are of a mucl less abrupt character than those just described; indeed, it is usually the case that the water is delivered so gradually to the water table that no change is noticed. Only in the shallow wells in coarse material can these fluctuations be identified, excopt in the cases of extraordinary rains, when the result is an irregularity of greater or less importance on the regular annual ground-water curve.

On Long Island the shallow wells near the south shore are affested by most of the important rains, although part of the fluctuations recorded are of the character just described. (See figs. 13, 15.) This is due to the coarseness of the surficial material and to the nearness of the water table to the surface. In the wells in which the ground water is farther from the surface the effect of any rain can not be positively identified. In the Wiener Neustadt records the effect of sing'e rains is entirely obliterated (Pl. IX), and in long observations of the chalk wators of England the general rule, to which, of course, there are exceptions where large underground caverns are concerned, is that the water is delivered very graduslly to the groundwater table.

PERCENTAGE OF RAINFALL CONTRIBUTED TO THE GROUNT WATER.

METHODS OF ESTIMATION.

In connection with this discussion of the fluctuation of the water level it may not be inappropriate to take up the allied question, to which reference has been made at several points, of the percentage of rain contributed to the ground water.

Estimates of this character have been made by three methods-(1) by means of the lysimeter, (2) by stream discharge, and (3) by changes in the level of the ground water.

\section{ESTIMATION OF PERCOLATION BY MEANS OF LYSIMETERE}

By the lysimeter method the rain water passing through a col xmn of soil in field conditions is measured directly. The gage used for this purpose consists of a vessel with impervious sides and a pervious bottom, filled with the soil to be tested, and buried so that the surface of the soil in the gage is at the sane level as the surrounding ground. The discharge through the pervious bottom of the vessel is collected by a cone and conducted by a small tube to the measuring gages. In the early forms of the apparatus used by Dalton, 1796, and Dickinson, 1835, surface outlets were provided to discharge the excess rainfall, but these were abandoned when it was found that on the level surface of the gage there was no surface run-off.

Many observations have been made along this line, and while the results for long periods clearly have a greater value than those for short periods, some of these shortperiod values have been included in the table on the following prge for the purposes of comparison.

Lysimeter results have been subjected to considerable criticism. and very differing views expressed regarding their value. It has been suggested (1) that the material in the gage is not in the natural condition of consolidation, and that, therefore, the results are too high; (2) that the underdrainage necessary to collect and carry the water from the base of the soil column to the measuring tube introduces an unnatural condition whereby the results are too low; $(3)$ that the surfase run-off factor is surpressed and the results are too high. 


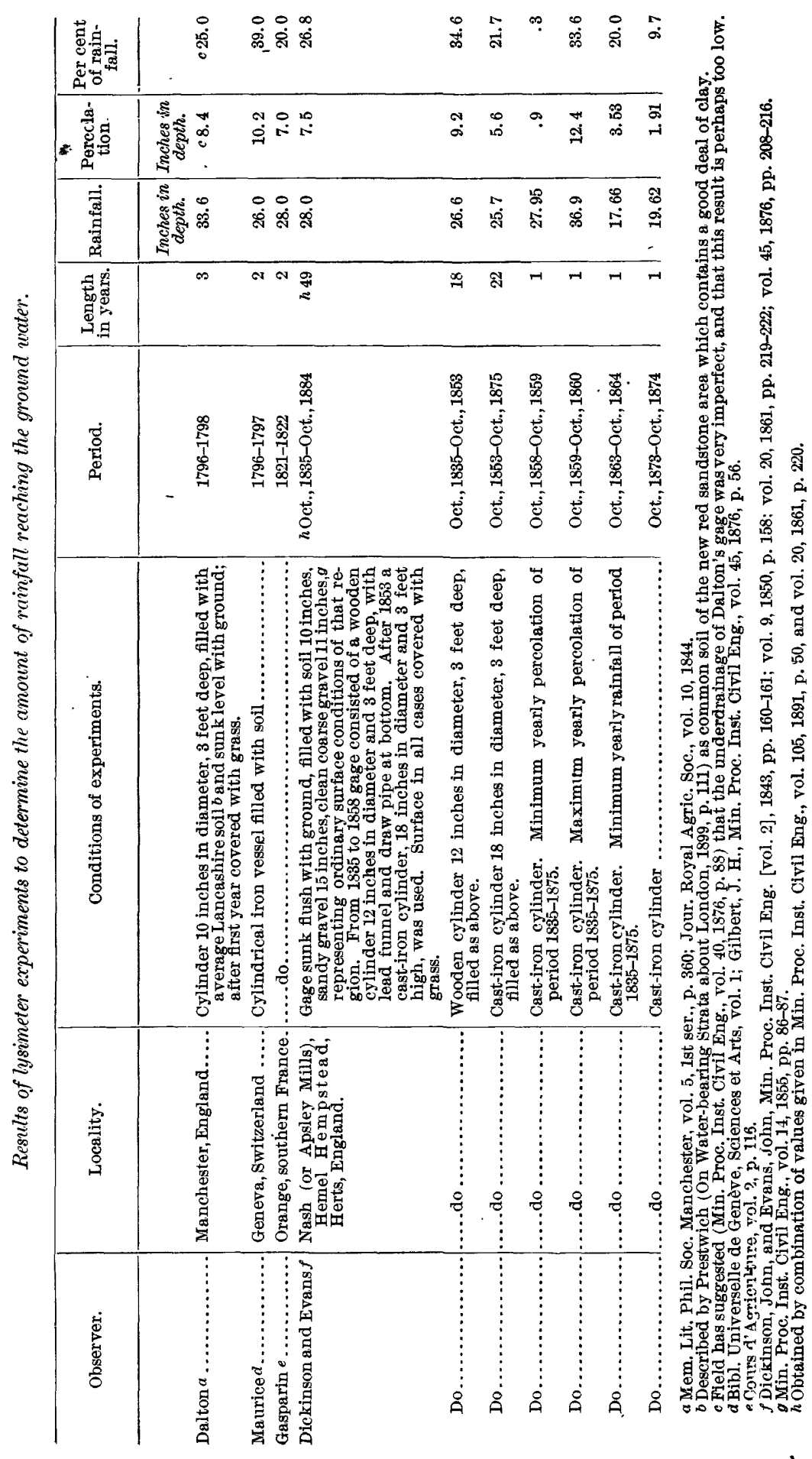




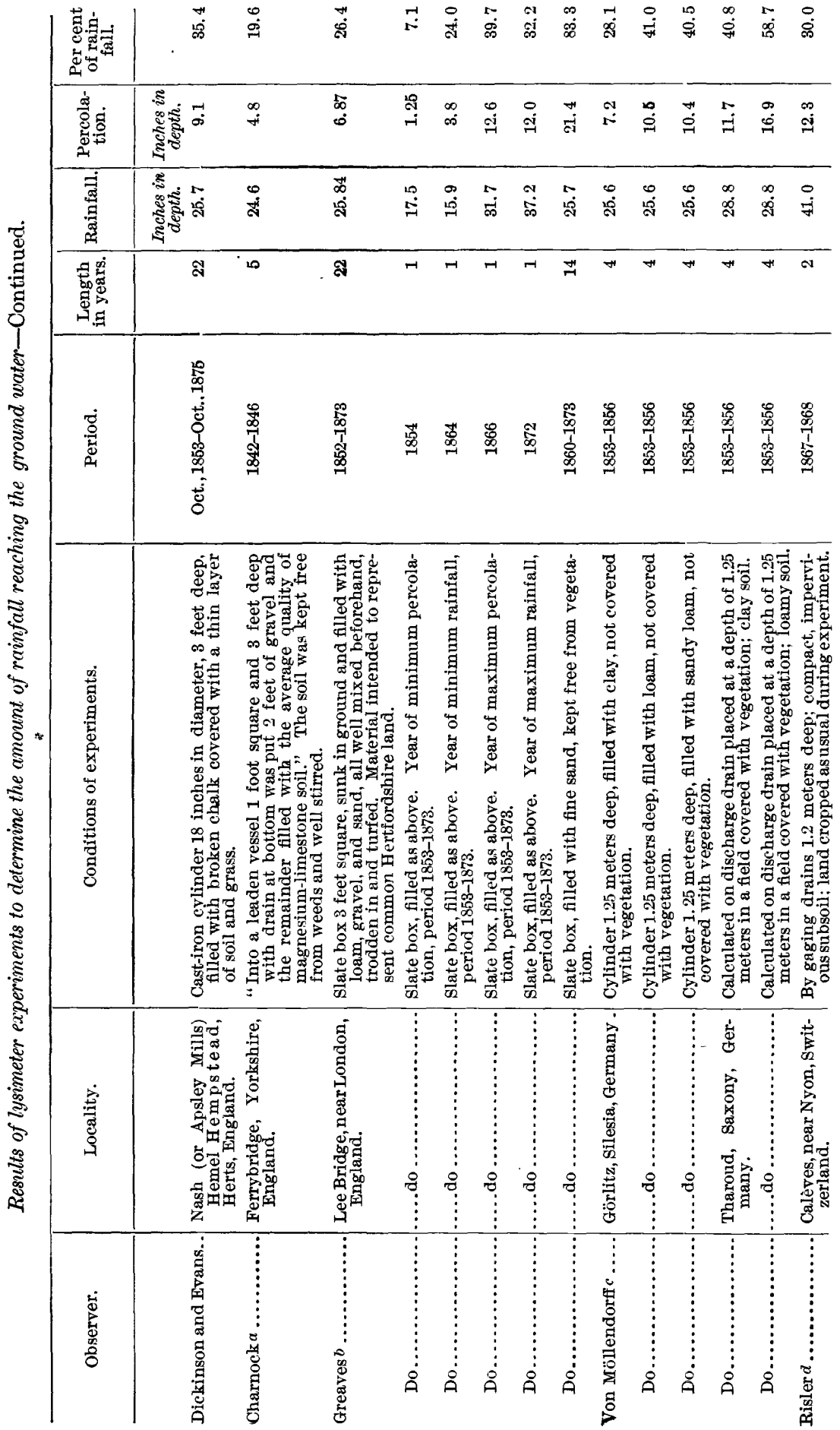


FLUCTUATIONS DUE TO RAINFALL AND EVAPORATION.

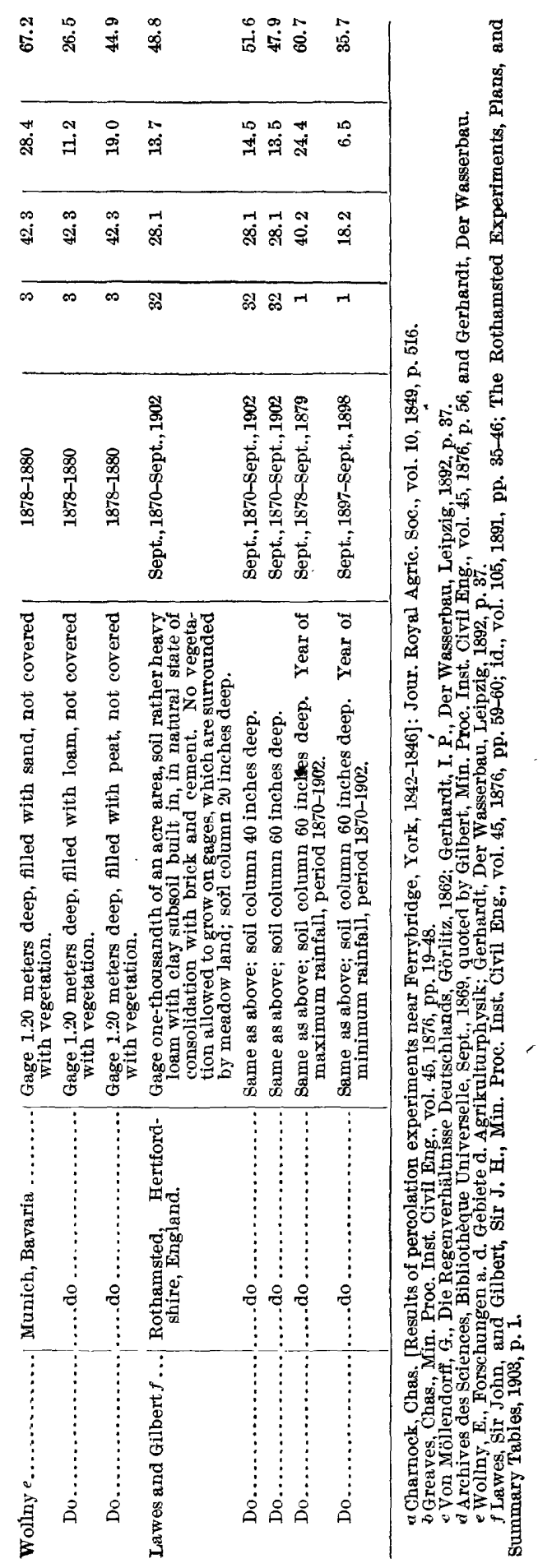


The objection regarding consolidation is well taken, though it clearly does not apply to the results at Rothamsted, where natural soil columns were used, and where very high results were obtained, or to other gages after the first few years, during which the soil has settled. In the Hemel Hempstead experiments the percolation between 1835 and 1843 was 42.5 per cent of the rainfall, while in the period 1835 to 1853 it was but 35 per cent, a decrease which is perhaps due in part to the gradual compacting of the soil, though it is also affected by the varying rate of percolation, for it must be remembered that the amount of percolation depents more on the time at which the rain falls and the manner in which it is distributed than on the actual amount.

Regarding the unnatural condition introduced by the method of drainage, it has been suggested on the one hand that the lower part of the soil column is thus exposed to evaporation, and that not only is there a loss in this manner not accounted for by the measuring gage, but that the dry condition of the basal layer would retard the percolation to a measureable extent and increase the loss by evaporation from the surface of the ground. Ebermeyer has shown, however, that with small lysimeters the lower portion of the soil column is damper than normal, " and he proposed to remedy this by constructing larger gages. These defects are clearly ones of construction which it is possible to remedy. At Rothamsted essentially the same results were obtained from soil columns 20,40 , and 60 inches high (fig. 12), showing conclusively that in this case the natural conditions were not essentially disturbed.

Indeed, it is believed that carefully conducted lysimeter observations, extending over long periods, such as are represented by the Dickinson and Evans and the Lawes and Gilbert experiments, give very important values bear'ng on this question, the Lawes and Gilbert results being particularly important and trustworthy. They indicate that in the climatic condition of middle England, with 28 inches of rainfall, half of the rainfall is contributed to the ground water through a rather heavy soil not covered with vegetation, and half of it evaporated. If the reinfall is greater, the percentage increases, if less, it decreases. Had the ground been covered with leaves, straw, or similar matter the percolation would have been greater; if covered with growing vegetation, less. Lawes and Gilbert estimate, from their observations on plant transpiration, that in this region 2 inches per year would represent the plant transpiration in the area of downs and waste land, where there was very little vegetation, while with a heavy grass or mangel crop it would amount to 7 inches or more. The average for the whole region was estimated at 3 to $t$ inches. This would make the percolation for soil of this character, in the case of downs an 1 waste land, 43 per cent; for the average mid-England district, 39 per cent, and for land covered with heavy grass or mangel crop, 25 per cent or less.

It should be noted in this connection that while the most of these observations, including those at Rothamsted, were made in connection with agricultural investigations, the Hemel Hempstead and Lee Bridge (Greaves) experıments were made for engineering purposes. The Hemel Hempstead observations were undertaken by a paper manufacturer, dependent on the water power of a spring-fed stream. He argued that stream flow depended on the amount of water which percolated through the soil; that measurements of this quantity would indicate the stream flow to be expected during the following summer. It is stated that he fo'nd that the indications of the gage during the winter enabled him to calculate the supply of water trom the stream during the ensuing season, that he had always tound the indication perfectly reliable, $b$ and that he was accustomed to regulate the volume of the orders accepted for the summer season by the indication of the gag? for the preceding winter. $c$ Clutterbuck adds, though the relation is clearly more of a qualitative than

a Reported by R. H. Scott, Jour. Royal Agric. Soc , 2d ser., vol. 17, 1881, pp, 66-67. $b$ Min. Proc. Inst. Civil Eng., vol. 2, 1842, p. 158.

I Ibid., p. 157 . 
a quantitative one, that the rise in level of the water in the wells in that region is found to coincide with the readings of the Dickinson gages. $a$

The lysimeter certainly furnishes a very direct and exact means of determining the amount of water contributed to the ground water at any given point. The principal objection to it is that the block of soil tested is not necessarily representative of the whole area under investigation.

Somewhat similar experiments, having for their object the determination of the evaporation from plants, have been conducted by many agriculturists in this country, notably by King, $b$ by means of tanks which can be lifted from the ground and weighed. This method is not so applicable to the amount of water contributed to the ground water as is the lysimeter type used above, for the results are less direct, the percolation being inferred from the evaporation generally under more artificial conditions than with the lysimeter.

estimation of PERcolation from the stream Discharge.

The favorite method of estimating the eraporation of a given drainage barin is to subtract the stream discharge expressed in inches of rainfall over the draingge basin from the average rainfall. Thus it is assumed that-

\section{Rainfall -Stream discharge $=$ Evaporation.}

The stream discharge is composed of (1) the rain water which flows into tl $?$ drainage channels without penetrating the soil-this 1s, strictly speaking, the rur off, but as this word is now by common consent used for the whole quantity of witer discharged by the river, this contribution may be somewhat arbitrarily referred to as the flood flow; and (2) the water which after a greater or less journey through the earth returns to the surface-this may be called the spring or ground-water flow of the river. It has been assumed that the ground-water flow of a river is its low-water flow and that any excess of this quantity can be regarded as flood flow. This is far frcm being a general fact. As the height of the ground-water table increases the stream discharge also increases, and it is possible to have high and low waters denendent entirely on the fluctuation of the ground-water discharge. In streams which cut the ground-water table and are ciearly ground-water-fed streams, such as those on Long Island, a rise in the ground-water table changes the position of the head of the stream, and by thus increasing both the head and the area of discharge greatly increases the stream flow. The total range of the ground-water table near the coast is much less than near the ground-water divide, and the discharge during periods of high groundwater level may therefore be disproportionate to the changes in level recorded by the wells near the coast. Because of these great changes in the area of the discharge and the relatively free flow of the surface water, it often happens that the fluctuations of the stream height in the lower part of the stream are greater than the changes in the level in wells in the same region.

Heavy rains, with no surface run-off, may likewise produce sudden and considerable rises by increasing the spring flow by transmitted pressure in the manner described above (p. 42). In the 14-foot well at Lynbrook (p. 23), besides the sudden rises recorded for every rain, the water four times during the period of observation rose above the surface. In the first instance the water, much to the arazement of the observer, gushed over the top of the pipe a few minutes after the shower began, and, while after the pıpe was raised this did not occur again, the records s'ow that on several occasions the water rose higher than the ground surface. There appear, then, to be great and almost insurmountable difficulties in the way of the satisfactory separation of the stream discharge into spring or ground-water flow and flood flow.

a Min. Proc. Inst. Civil Eng., vol. 9, pp. 153, 156.

b Ann. Repts. Wisconsin Agric. Expt. Station, 1892, pp. 94-100, 1893, pp. 152-109, 1894, fp. 240-280; 1897, pp. 228-231.

IRR $155-06-4$ 
- It is the belief of the writer that in the eastern United States the portion of the total stream flow attributed to ground-water contributions is commonly greatly underestimated.

On Long Island Spear, from a comparison of the hydrographs of several of the streams near the south shore with the fluctuation in neighboring wells, has concluded that of the total stream discharge but 57 per cent is spring or ground-water flow. ${ }^{a}$ This is an extremely low value, and from a consideration of the various factors involved it is believed that 90 per cent is much nearer the true value. On this basis the flood flow is but 3 or 4 per cent of the yearly rainfall.

In the simple equation, Rainfall-Stream flow=Evaporation, no account is taken of the underflow, it being assumed that all the ground water is returned to the stream above the point at which the measurement is made, an assumption which is far from correct. The result of this is to give to the evaporation a value just as much in excess of its true value as there is loss by underflow. Thus on Long Islar $\%$, where the percolation is perhaps 60 per cent of the rainfall, the estimate of Spear ${ }^{b}$ gives the total normal stream discharge as 33 per cent of the rainfall, and the estimates of the Brooklyn water department are still lower. This, according to the above formula, would give a loss by evaporation of 67 per cent, when it is actually about 40 per cent. It may be assumed, however, except in regions deeply covered with loose superficial material, such as Long Island, that the loss by underflow is less than the excess by flood flow, and that the total stream flow represents a quantity slightly larger than the percolation. With this in mind, some idea of the amount of percolation can be obtained from the following values:

Rainfall and run-off of drainage basins in the United States.

\begin{tabular}{|c|c|c|c|c|c|}
\hline Drainage basin. & $\begin{array}{l}\text { Years of } \\
\text { record. }\end{array}$ & $\begin{array}{c}\text { Average } \\
\text { yearly } \\
\text { rainfall. }\end{array}$ & \begin{tabular}{|c|} 
A verage \\
yearly \\
stream \\
flow.
\end{tabular} & $\begin{array}{l}\text { Percent- } \\
\text { age: } \\
\text { Stream } \\
\text { flow of } \\
\text { rainfall. }\end{array}$ & Authority. \\
\hline & & $\begin{array}{l}\text { Inches of } \\
\text { depth. }\end{array}$ & $\begin{array}{c}\text { Inches of } \\
\text { depth. }\end{array}$ & & \\
\hline Watershed of southern Long Island. & n....... & 42.56 & 14.0 & $33 . \mathrm{C}$ & Spear. \\
\hline Muskingum River, Ohio .......... & $1888-1895$ & 39.7 & 13.1 & $33 . \mathrm{C}$ & Rafter. \\
\hline Genesee River, N. Y......... & $1890-1898$ & 40.3 & 14.2 & $35 . C$ & Do. \\
\hline Lake Cochituate, Mass ........ & $1863-1900$ & 47.1 & 20.3 & $43, \mathrm{C}$ & Do. \\
\hline Mystic Lake, Mass...... & 1878-1895 & 44.1 & 20.0 & 45. $\tilde{E}$ & Do. \\
\hline Croton River, N. Y ........... & $1865-1899$ & 48.07 & 22.33 & 46.5 & Freeman. \\
\hline Neshaminy Creek, Pa... & $1884-1899$ & 47.6 & 23.1 & 48.5 & Rafter. \\
\hline Sudbury River, Mass.... & $1875-1900$ & 46.1 & 22.6 & $49 . \mathrm{C}$ & Do. \\
\hline Sudbury River, Mass ... & $1875-1902$ & 46.38 & 22.75 & $49 . C$ & $\begin{array}{l}\text { Metropolitan water- } \\
\text { works. }\end{array}$ \\
\hline Perkiomen Creek, Pa.. & $1884-1899$ & 48.0 & 23.6 & 49.0 & Rafter. \\
\hline Connecticut River, Conn.... & $1872-1885$ & 43.0 & 22.0 & 51.0 & Do. \\
\hline Hudson River, N. Y............... & $1888-1901$ & 44. 2 & 23.3 & 52.7 & Do. \\
\hline Nashua River, South Branch, Mass.. & $1897-1902$ & 51.32 & 27.56 & 53.7 & $\begin{array}{l}\text { Metropolitan water- } \\
\text { works. }\end{array}$ \\
\hline Pequannock River, Conn .. & $1891-1899$ & 44.2 & 26.8 & 60.6 & Rafter. \\
\hline
\end{tabular}

In this table the large loss by underflow in the Muskingum and Genesee drainage basins is evident.

ESTIMATION OF PERCOLATION FROM CHANGES IN LEVEL OF THE GROUND-WATER TARTE,

The broader and more important fluctuations of the ground-water table are clearly due to the infiltration of water, and attempts have been made remeatedly to estimate 
the amount of infiltration by the rise in the ground water. After having detarmined the available pore space, which is by no means a simple matter, it appears vory easy to calculate the amount of water which will cause the water level to rise a few inches or a few feet. The method is an attractive one, with an appearance of exact ress and simplicity, and has often been tried. The results have very little meaning, however, for the very important reason that the same rainfall under the same climati? conditions will produce very different rises in material of the same porosity; for, as pointed out previously (p. 38), the amplitude of the fluctuation increases with the distance from the ground-water discharge. Thus, with material of the same porosity, an annual rainfall of 25 inches produces at Wiener Neustadt a fluctuation in one well of 1 foot, and in another a fluctuation of 25 feet (Pl. IX). It is evident that a calculation of infiltration hased on the rise of water produced in well No. 1 , will give very different values from that of No. 2, and yet it may be confidently asserted that the same amount of percolation is received in both. Similarly, in the chalk ragion of England, the fluctuation in the same region ranges from a few inches to 50 or 100 feet. The impossibility of accurately calculating the amount of percolation from the rise of the ground-water table is evident.

\section{REFERENCES RELATING TO WELL FLUCTUATIONS DUE TO RAINFALL AND EVAPORATION.}

The bibliography relating to fluctuations of water in wells due to rainfall is naturally very extensive, and an attempt has been made to collect a few only of these titles, important either for their general bearing or their special reference to the United States:

Auchincloss, W. S. Waters within the Earth and Laws of Rainflow, Philadelphia, 1897.

Gives record of fluctuations in well at Bryn Mawr, Pa., 1886-1895, showing annual an secular fiuetuations.

Barbour, Erwin Hinckley. Water-Sup. and Irr. Paper No. 29, U. S. Geol. Survey, 1899, p. 28; Nebraska Geol. Survey, Rept. of State Geologist, vol. 1, 1903, p. 106.

States that wells in Nebraska show an annual fluctuation independent of the rainfall. with the maximum occurring in February.

Clutterbuck, James. Observations on the periodic drainage and replenishment of the subterraneous reservoir in the chalk basin of London: Min. Proe. Inst. Civil Eng. [vol. 2], 1842, pp. 155-165; 1843, pp. 156-159.

- On the periodic alternations and progressive permanent depression of the chalk-water level under London: Min. Proc. Inst. Civil Eng., vol. 9, 1850, pp. 151-180, Pl. VI.

Emery, Frank E. Notes on fluctuations in height of water in an unused well: Eighth Ann. Rept. New York Agric. Expt. Station for 1889, 1890, pp. 374-375, fig.

Records monthly observations from December, 1886, to December, 1889, on a 40 -foct well at Geneva, N. Y., which shows a single yearly period independent of the rainfall.

Fortier, Samuel. A preliminary report on seepage water and the underflow of rivers: Bull. Utah Expt. Station No $38,1895$.

On p. 30, under heading "Effect of subsurface temperature on rate of flow," are given discharge, temperature, and rainfall at Denver Water Company's plant at Cherry Creek, frc $m$ 1888 to 1891. This is an infltration gallery in fine sand 15 feet below the surface, and the discharge shows a rather regular yearly fluctuation with a minimum in February-March and a maximum, normally, in August-November. This fluctuation is ascribed by Fortier to changes in soil temperature. It should be pointed out, however, that, while the annual changes in soil temperature do affect the rate of flow (see p. 59), the yearly maximum is independent of this fluctuation and the agreement here is merely a coincidence.

FreUnd, ADolph (secretary). Bericht des Ausschusses für die Wasserversorgung Wiens, Örterreichischen Ingenieur- und Architekten-Verein, 1895.

Pl. V, Graphische Darstellung der Wasserstände im Steinfelde, 1883-1888.

GERHARDT, P. I. Handbuch der Ingenieurwissenschaften, vol. 3, Der Wasserbau, pt. 1, 1892, pp. 46-51. Under heading "Schwankungen des Grundwas ers," gives a summary based largely on the reports of Soyka.

Headden, Wilhelm P. A soil study, pt. 4, The ground water: Bull. Colorado Agric. Exp ${ }^{+}$. Station No. $72,1902$.

Gives data regarding effect of single showers.

King, Franklin H. Fluctuations in level and rate of movement of ground water: Bull. U. S. Weather Bureau No. 5, 1892, pp. 72-74.

Discusses instantaneous percolation after rains. 
King, Franklin H. Principles and conditions of the movement of ground water: Nineteenth Ann. Rept. U. S. Geol. Survey, pt. 2, 1899, pp. 100-106.

Discusses "Elevation of ground-water surface due to precipitation an 1 percolation," largely from standpoint of porosity.

LrzNaR, Josef. Ueber die periodische Änderung des Grundwasserstandes, $\mathrm{e}^{\text {i }}$ Beitrag zur Quellentheorie: Gæa, vol. 17, 1881, p. 330; Meteorol. Zeitschr., Wien, vol. 17, 1882, pp. 368-371.

LuEgER, OTTo. Die Schwankangen des Grundwassers: Gæa, vol. 24, 1888, p. f30.

Michigan State Board of Health. Annual reports, 1878-1903.

Contain monthly observations of water level at many points in Michigan.

SoYKA, Isidor. Experimentelles zur Theorie des Grundwasserschwankungen: Vierteljahrsschrift für öff. Gesundheitspflege, vol. 4, 1885, p. 592.

- Der Boden (Handbuch des Hygiene und der Gewerbekrankheiten, vol. 2, pt. 3), Leipzig, 1887, pp. 251-351.

Contains much of the material incorporated in the following report.

Die Schwankungen des Grundwassers mit besonderer Berücksichti६ung der mitteleuropäischen Verhältnisse: Penck's Geographische Abhandlungen, vol. 2, pt. 3, Wien, 1888.

SPear, W W W ter E. Long Island sources: Rept. New York City Commission on Additional Water Supply, appendix 7, 1904, pp. 816-826.

Discusses fluctuation in elevation of ground-water surface.

TodD, JAMEs E. Water-Sup. and Irr. Paper No. 34, U. S. Geol. Survey, 1900, p 29.

The normal yearly maximum is here tentatively referred to the melting of snows or floods.

Tribus, L. L. Trans. Am. Soc. Civil Eng., vol. 31, 1894, pp. 170, 391-395.

Reports (p. 170) that in driven wells in New Jersey, 50 feet deep, the effect of rain was rarely felt in less than thirty hours; gives curve (pp. 391-395) showing fluctuation of water level in 50-foot well at Plainfleld, N. J., waterworks, 1891-1894. This shows normal annual curves slightly affected by pumping.

WoLDŔICH, JOHANN NEPOMUK. Ueber den Einfluss der atmosphärischen Niederschläge auf das Grundwasser: Zeitschr. Meteorol., Wien, vol. 4, 1869, pp. 273-279.

- Ueber die Beziehungen der atmosphärischen Niederschläge zum Fl >ss- und Grundwasserstand: Mitt. d. Techn. Klubs zu Salzburg, pt. 1, 1869.

\section{FLUCTUATIONS DUE TO BAROMETRIC CHA]'GES.}

\section{CHARACTER AND CAUSE.}

Changes in air pressure have been observed to affect wells in two ways; in some there is an inflow and outflow of air, and in others a rising and lowering of the water level. $a$ The rise or outflow occurs with a falling barometer, and the depression or inflow with a rising barometer. In the case of flowing wells, wh en the external air pressure decreases, the air within the earth expands, and, as the escape through the soil is greatly retarded by friction and as the well offers a free excape, it finds relief through the well tubing. The power of this blast evidently depends on the area tributary to the well, the loss by friction, and the rate of lowering of the outside pressure. On the other hand, with a rising barometer the exterral air flows into the pipe to supply the volume lost by the compression of the soil air or earth air. If water is interposed between this included air and the well, the well becomes a rough differential-pressure gage in which the maximum change possiblo is about 12 inches of water for each mercurial inch of variation in the barometric pressure.

Where there is no soil air suitably confined to produce the result just described, the air and other gases in the water so increase its compressibility that a small, though measurable result may be produced by the direct comprescion and expansion of the water. In the latter case the depth of water involved is an important factor, and it is probably for this reason that on Long Island, where the earth air occurs only in the porous surficial soil, from which it is relatively free to escape, in the wells at Lynbrook fluctuations due to barometric changes are clearly noticeable only in the 504-foot well, and these are relatively small. An examination of Pl. VI shows that there are no indications of barometric influence on the curres from the 72 -foot well, but that in the 50t-foot well there is a striking resemblance. The similarity is, however, in some places due in part to other causes. Thus the elevations of the water on July 18-19, August 5, and September 16, while closely following the barometric

$a$ See in this connection Nineteenth Ann. Rept. U. S. Geol. Survey, pt. 2, 1899, figs. 3, 4, 5; WaterSup. and Irr. Paper No. 67, U. S. Geol. Survey, 1902, fig. 39, p. 73 . 
curve, are partly due to rainfall. This is indicated by the fact that somewhat similar abrupt barometric depressions on July 26, August 20, and September 4-5, when there were no important rains, did not produce similar elevations of the water in the well. There is a further point of resemblance and dissimilarity between the curve for the 504-foot well and the barometric curve. The well curve shows a very marl ed semidiurnal fluctuation, the two parts of which are generally of about the same value, although they sometimes merge into a pronounced diurnal wave, as on Aurust 1, 2, and 3. In the barometric curve, although there is a tendency toward a semidiurnal well wave, it is nowhere well marked. The semidiurnal well wave is clearly not tidal. Its resemblance to the barometer curve is, however, sufficiently close to lead to the belief that it is largely barometric, but modified by some other element, perhaps the diurnal temperature wave which shows in the 14- and 72-foot wells (pp. 24-25).

\section{REFERENCES RELATING TO WELL FLUCTUATIONS DUE TO BAROMETRIC CHANGES,}

\section{BLOWING WELLS.}

Barbour, Erwin Hinckley. [Blowing wells in Nebraska]: Water-Sup. and Irr. Paper No. 29, U.S. Geol. Survey, 1889, pp. 78-82; Nebraska Geol. Survey, Rept. of State Geologist, vol.1, 1903, pp. 93-97.

FarRLex, T. On the blowing wells near North Allerton: Proc. Yorkshire Geol. and Polyt. Soc., n.s., vol. 7 , pt. 3, 1880 , pp. 409-421, Pl. VII.

HaRris, Gilbert Dennison. [Blowing wells in Rapides Parish, La.]: Water-Sup. and Irr. Paper No. 101, U. S. Geol. Survey, 1904, pp. 60-61; Louisiana Geol. Survey, Bull. No. 1, 1905, pp. 59-60.

LANE, AlFred C. Water-Sup. and Irr. Paper No. 30, U. S. Geol. Survey, 1899, pp. 55-56. Records shallow blowing well in Michigan.

Veatch, A. C. Prof. Paper U. S. Geol. Survey No. 44, 1906, p. 74.

Records reported occurrence of blowing wells on Long Island, New York.

\section{CHANGES IN WATER LEVEL.}

ATWELl, Joseph, Conjectures on the nature of intermitting and reciprocating springs: Trans. Phit. Soc. London, No. 424, vol. 37, 1732, p. 301; Trans. Phil. Soc. London from 1665-1800 (abridged), vol. 7, 1809, pp. 544-550.

Describes irregular fluctuations of short interval in springs at Brixam, near Torbay, in Devonshire called "Lay well." These, he supposes, are produced by the action of natural siphons. Perhaps they are barometric fluctuations.

Denjzer. Sources sujettées à đes variations qui paraîssent liées à l'état du baromètre: Comptes rendus, vol. 7,1839, p. 799.

Reports that springs at Voize are affected by changes in barometric pressure, and that the discharge is directly related to the pressure, instead of inversely, as has been proved by more recent work.

GoUGH, JoHs. Observations on the ebbing and flowing well at Giggleswick, in the West, Riding of Yorkshire, with a theory of reciprocating fountains: Jour. Nat. Phil. Chem. Arts, ser. 2, vol. 35, 1813, pp. 178-193; Mem. Phil. Soc. Manchester, n. s., vol. 2, 1813, pp. 354-363.

The water level in this well fluctuates irregularly at short intervals, and Mr. Gough suggests that the fluctuations are produced by the obstruction resulting from the natural accumulation of air bubbles in the outlet and the relief resulting from their irregular escape. He citics the irreggular fluctuations of the Weeding well in Derbyshire and the Lay well near Torbay, as proving that the prevailing idea of the production of these phenomena by natural siphons is erroneous. He concludes, very correctly, that too little is known of the fountain of Jupiter in Dodona and Pliny's well in Como to judge of the true cause of the fluctuations mentioned by Pliny.

KING,FRANKLIN H. [Influence of barometric ehanges on discharge and water level in wells and springs at Madison and Whitewater, Wis.]: Bull. U. S. Weather Bureau No. 5, 1892, pp. 44-53; Nineteenth Ann. Rept. U. S. Geol. Survey, pt. 2, 1899, pp. 73-77.

LATHAM, BALDWIN. On the influence of barometric pressure on the discharge of water from springs: Brit. Assoc. Rept. for 1881, 1882, p. 614; Brit. Assoc. Rept. for 1883, 1884, pp. 495-496.

The fluctuation of the Croydon Bourne, due to barometric pressure, on one occasion exceeded half a million gallons per day. Observations in deep wells are also recorded, showing that fluctuations are inversely related to the pressure. The fluctuations are attributed to the expansion and contraction of the air and gases in the water.

KNIGHTLEY, T. E. Ebbing and flowing wells [in Derbyshire, England]: Geol. Mag., n. s., decade 4, vol. 5,1898 , pp. $333-334$.

Suggests that irregularities in flow are due to cavernous limestone, which, by means of natural siphons, gives rise to "intermittent spring phenomena." The possibility of th ese fluctuations being due to barometric changes is not considered. 
LUEG ER, OTto. Einfluss der A tmosphärendruckes auf die Ergiebigkeit von Brunnen und Quellen: Centralblatt d. Bauverwaltung, 1882, p. 8.

Milne, John. Seismology. London, 1898, p. 243.

Reports two sinkings and two risings of about 5 miliimeters in a shallow well near Tokio. The sinkings took place between 2 and $6 \mathrm{p} . \mathrm{m}$. and 2 and $5 \mathrm{a} . \mathrm{m}$. Note: These flretuations suggest the diurnal barometric wave, but they can be referred to it only if the time given is taken to mean the time at which the water commenced to sink and not the time of the low-water atage.

Oliver, Dr. William. Of a well that ebbs and flows . . . : Trans. Phil. So?. London, No. 204, vol. 17, 1693, p. 908; Trans. Phil. Soc. London from 1665-1800 (abridged), vol. 3, 1809. pp. 585-586.

Describes well near Torbay called "Lay well," that ebbs and flows from 16 to 20 times per hour. See Atwell, above, and discussion of minor periodic fluctuations on p. 75 .

Pliny the Younger (Cains Plinius Cæcilius Secundus). Epistolæ, 1ib. 4, epist. ult.

In his letter to Licinius Pliny describes the fluctuations in the discharga of a spring near his villa in Como, Italy, which he states ebbs and flows thrice a day. He suggests that the fluctuations may be due to "the obstruction of air," tidal action, or some secret and unknown contrivance in the nature of a valve. Pliny the elder, in his Historia Naturalis, lib. 2, cap. 106, refers to the same spring, but states that it ebbs and flows every hour-a statemert which is verified by Catanæus, the learned commentator on the Epistles. From the meager and contradictory data given it is unsafe to venture a decided opinion on the cause of these fiuctuations, but they may be tentatively regarded as barometric.

ROBERTS, IsAac. On . . . the variation in atmospheric pressure . . . causing oscillations in the underground water in porous strata: Rept. Brit. Assoc. for 1883, p. 405.

States that autographic records from a well at Maghill, near liverpool, show such fluctuations.

Slichter, Charles S. Water-Sup. and Irr. Paper No. 67, U. S. Geol. Survey, 1902, pp. 71-72.

Refers to reports of Latham, King, and Lueger.

Tod, Jam fs E. Bull. Geol. Survey, South Dakota, No. 2, 1898, p. 116; Water-Sup. and Irr. Paper No. 34, U. S. Geol. Survey, 1900, p. 29.

Reports that well discharge varies inversely with barometic pressure.

\section{FLUC'TUATIONS DUE TO TEMPERATIRE CHANGES.}

\section{OBSERVATIONS AT MADISON, WIS.-FLUCTUATIONS VARYING DIRECT:'Y WITH THE TEM- PERATURE.}

In $1888 \mathrm{King}$ observed in certain shallow wells at Madison, $W$ is., that the water regularly for a portion of the summer months stood higher in the morning than at night. a Further observations during the period 1888 to 1892 showed that there was in many wells a diurnal wave, distinctly marked during the summer and dying out in winter, which was clearly not barometric in character, and was not produced by the unequal plant transpiration during the day and night. Suspecting that these changes were intimately related to temperature, King tried the following experiment:

A galvanized-iron cylinder, 6 feet deep and 30 inches in diameter, provided with a bottom, and water-tight, was filled with soil, standing its full height above the ground in the open field. In the center of this cylinder and extending to the bottom a column of 5 -inch drain tile was placed and the soil flled in about it and packed as thoroughly as practicable. Water was roured into the cavity formed by the tile until it was full, and allowed to percolate into the soil so as to saturate it and leave the water standing nearly a foot deep in the well. When the water in this artificial well had become nearly stationary one of the self-registering instruments was placed upon it. $b$ In order to avoid any complications due to percolation, the apparatus was provided with a cover wh ich could be put on in times of rain and removed again during fair weather. The flrst records showed a small diurnal oscillation, and as the season advanced these increased in amplitude until finally the water rose in the well during the day of July 8,1.8 inches and fell during the following night 1.84 inches. After these diurnal oscillations had become so pronounced and so constant, a series of thermometers were introduced into the side of the cylinder, extending to different distances from the surface, and a record kept of the changes in the soll temperature; and the result of these observations was to show that the turning points in the water curve fell exactly upon the turning points of the temperature of the soll in the cylinder. When this fact was ascertajned, to show whether the corresfondence in the time of the two curves was due to a diurnal cause, other than temperature, which ha ${ }^{\text {its }}$ turning points so related to those of the temperature as to cause the two to accidentally fall tugether, cold water was

$a$ King, Franklun H., Observations and experiments on the fiuctuations in the level and rate of movement of ground water on the Wisconsin Agricultural Experiment Station Farm and at Whitewater, Wis.: Bull. U. S. Weather Burean No. 5, 1892; also Ann. Repts. Wisconst' Agric. Expt. Station, 1889-1893.

$b$ For a figure of this apparatus see Bull. U.S. Weather Bureau No. 5. 
brought from the well and, with a spray pump, applied to the surface of the cylinder all around. The water was applied on a hot sunny day, just after dinner, when the water was rising in the well, and the result was an immediate change in the curve, the water beginning to fall in the well. The water was then turned off, and the result of this change was to stop the fall of the water in the well, as shown by a change in the direction of the curve.

This led to the conclusion that there was a very positive connection between the changes in the soil temperature and changes in the level of the water in the wells, and that the fluctuation varied directly with the temperature; that is, the water in the wells rose with increasing temperature and fell when the temperature lowered. A specially constructed self-recording soil thermometer showed that at a cepth" of 18 inches the minimum temperature occurred at noon, and the the maximum a little after midnight. It was therefore argued that at a depth of 3 feet, or the level at which the wells were fluctuating, the maximum and minimum temperaturs would occur still later, and that the high water which occurred in the wells at 8 o' clock in: the morning was due to the maximum temperature falling at that time at that depth. The autographic records, moreover, show that the well curves have the same characteristic as the temperature curve- there is in both a comparatively sudden rise and a long fall. King at first believed that these fluctuations were produced by a variation in the capillary action of the soil resulting from the change in temperature, $a$ but afterwards concluded that the fluctuations were due not so much to "a chance in the viscosity of the ground water as to variations in pressure due to the expansion and contraction of the gas confined in the soil within and above the water." $b$

Changes in capillary attraction and surface tension, due to temperature changes, are quite competent to produce fluctuations which are related to the temperature in the way observed. A rise in temperatire, by decreasing the capillary attraction, causes some of the capillary water above the water table to be added to the zone of complete saturation, and so increases the level of the water in wells. Conversely, a decrease of temperature, by increasing the surface tension and capillary attraction, causes water to be transferred from the ground water to the partially saturated zone above it, and so lowers the water in wells. There is, then, a continual interchange, a flux and reflux, between the ground water and the water in the partially saturated zone above it. The amount of water involved in this change is probably sm?ll, but, because of the very small amount of unoccupied pore space existing immediate' $y$ above the zone of saturation, a very slight shifting of water can produce a fluctuation of several inches in the surface of the zone of saturation or the water level in a well. This effect is marked only when the bottom of the well (supposing the well tuk to be impervious) is very near the top of the ground-water table; it is not shown in deep wells because, while the position of the ground-water table is constantly changing in this way, there is, so far as deeper points are concerned, no important chánge in pressure. The total pressure at a given point below the ground-water table is essentially the same whether the water involved is in the saturated zone or 2 or 3 inches above it in an almost saturated layer. To this, more than to the lact that the variations in soil temperature at a given depth are less in winter than in summen, is due the fact that these fluctuations at Madison, Wis, , were not shown by the twice-daily observations, made morning and evening between 1888 and 1892 , until past or near the middle of July (when the water was nearing its yearly minimum), and from that time increased toward a maximum, occurring sometime in August (probably corresponding with the ground-water minimum), and then died away until the middle of October, when they became inconspicuous. It likewise explains the fact that not all the wells observed, though they were in a limiter area, show these fluctuations, and why they begin at different times in adjacent wells of different depths.

$a$ Bull. U. S. Weather Bureau No, 5, 1892, pp. $63,67$.

$b$ Bull. U. S. Weather Bureau No. 5, 1892, p. $72_{2}$ Nineteenth Ann. Rept. U. S. Geol. Survey, pt. 2, 1899 , pp. 75,77 . 
To this relation are due the apparently anomalous phenomena observed in "well No. 5," which King records as follows:

The ground-water level had fallen until well 5 was likely to become dry. In order not to lose the records it was deepened by boring a hole in the center and curbing it with sections of 5 -inch drain tile in the manner represented in the figure, $a$ which shows the two water surfaces whose fluctuations are recorded in fig. 16. The original well, having an inside diameter of 1 foot $8 . n d$ a depth of 5.5 feet, was bricked up to within 2 feet of the surface and then finished with a section of sewer pipe, as shown in the cut, $a$ where the character and arrangement of the soil through which the well penetrated may also be seen. $b$

The facts are, strange as it does appear, that under these conditons and in such close juxtaposition, oscillations so unlike in their character as the two under consideration were produced simultaneously. The level of the water in the outer well oscillated so as to stand in the mornirg from 0.1 to 0.3 inch above the level of the water in the inner one, and at night from 0.5 inch to 1.2 inches below that surface, and these differences were maintained with only the unglazed section of drain tile separating them. The large oscillations in this well became very pronounced and constant only a short time before it became dry, and the inner well did not take up the marked changes in level after the water fell below the bottom of the original well. No other well of this series, although constructed in the same manner, showed such marked oscillations.

The second suggestion, that the fluctuations are produced by the expansion and contraction of the air due to temperature changes, is not supported by the observed facts. The daily temperature fluctuation at the depths observed amounts to but a fraction of a degree, and the change in volume or vapor tension of the air resulting from this is quite incompetent to produce the fluctuations observed. Moreover, this involves an elevation in the well due to pressure of much the same character as that producing the fluctuations due to barometric changes. The effects of such pressure changes are felt not only at the surface of the zone of complete saturation, or the water table, but are transmitted for many feet below it, and in the case of well No. 5, described above, the fluctuations under such conditions would be shown in both wells, though in the deep one the amplitude would be slightly less.

On the whole there seems to be no other alternative than to regard these Madison fluctuations as the result of variations in the capillary attraction and surface tension, of the water above the zone of complete saturation, produced by variations in temperature.

In fluctuations of this character a limiting factor is clearly the range of temperature, which decreases very rapidly with depth, so that at a relatively shallow depth, much less than the limit of no annual change, the fluctuations bacome imperceptible. The amplitude will, moreover, be affected by the size of the pore spaces, being greater in fine than in coarse material.

OBSERVATIONS AT LYNBROOK, N. Y.-FLUCTUATIONS INVERSETY RELATED TO TEMPERATURE.

Two of the wells at Lynbrook show pronounced fluctuations wl ich are clearly due to temperature changes. These fluctuations, while they resemble those observed at Madison in the fact that the water is higher in the morning than at night, differ from them in two important respects. There is no connection between their occurrence and the relation of the ground-water table to the bottom of the well; they are best developed in a 2-inch well, 14 feet deep, whose bottom is abcut 13.75 feet below the ground-water level; they are distinctly developed in a well 72 feet deep, and are believed to form one of the elements in a compound curve obtained from the 504foot well (Pl. VI, p. 24). There is also the further difference that, while these are clearly temperature fluctuations, they are inversely related to the temperature-that is, the water is high when the temperature is low. Avoiding all discussion of the

$a$ Omitted in this report.

$b$ The stratification, as shown iu the original cut, is as follows:

Section of well at Madison, Wis., which furnished fuctuations shoun in fig. 16.

1. Loam.

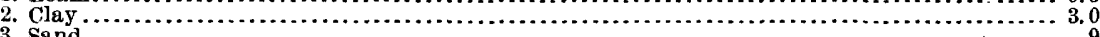

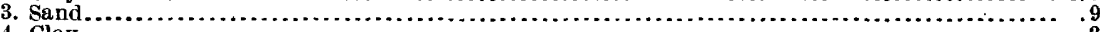

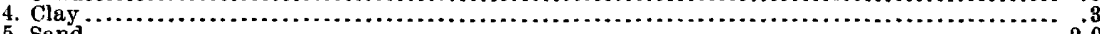

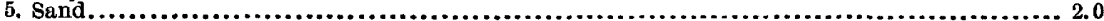


question of lag, this relation is conclusively shown by the shape of the curves. The characteristic of the air temperature curve is a quick rise and slower fall; well fluctuations directly related to the temperature, as those at Madison, therefore must show a quick rise and a slower fall, but in the Lynbrook wells there is a quick fall and slower rise (see Pl. VI, Aug. 1-3). These evidently belong in quite a different class from the temperature fluctuations observed at Madison, and involve quite a different relation between the soil temperature and the ground water.

The soil is a very poor transmitter of heat, and there is not only a very rapid diminution of the temperature range with depth, but a very considerable time lag. Swezey's observations $a$ at Lincoln, Nebr., for a period of fourteen years show that while in winter the maximum temperature occurs in the air at about the middle of the afternoon, at a depth of 3 to 6 inches it occurs in the evening, and at 1 foot it is delayed until the following morning; below 1 foot it is scarcely appreciable. In summer the daily range is considerably greater at all depths, the changes are appreciable to a depth of at least 2 feet, and are retarded to about the same extent as in winter.

At Bronx Park, New York City, the record obtained by MacDougal $b$ with a Hallock thermograph showed that at 1 foot below the surface the maximum daily temperature occurred between 8 and 11 p. m., and the minimum between 8

a Swezey, G. D., Soil temperature at Lincoln, Nebr., 1888 to 1902: Sixteenth Ann. Rept. Nebraska Agric. Expt. Station for 1902, 1903, pp. 95-129; Expt. Station Record, vol. 15, 1904, pp. $460-461$.

b MacDougal, Daniel Trembly, Soil temperaturesand vegetation: Month. ly Weather Review, vol. 31, August 1903, pp. 375-379.

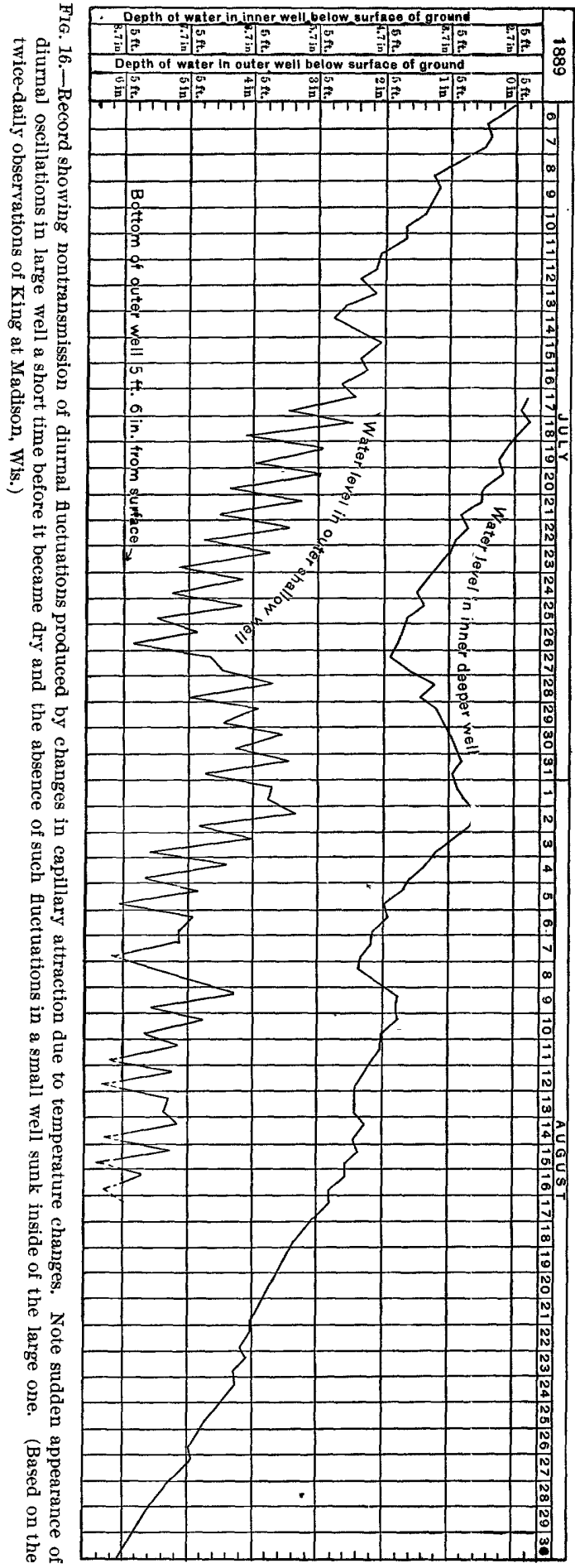


and 10 q. m.; and the maximum daily range was but $2^{\circ} \mathrm{C} .\left(36^{\circ} \mathrm{F}\right.$. $)$, which was

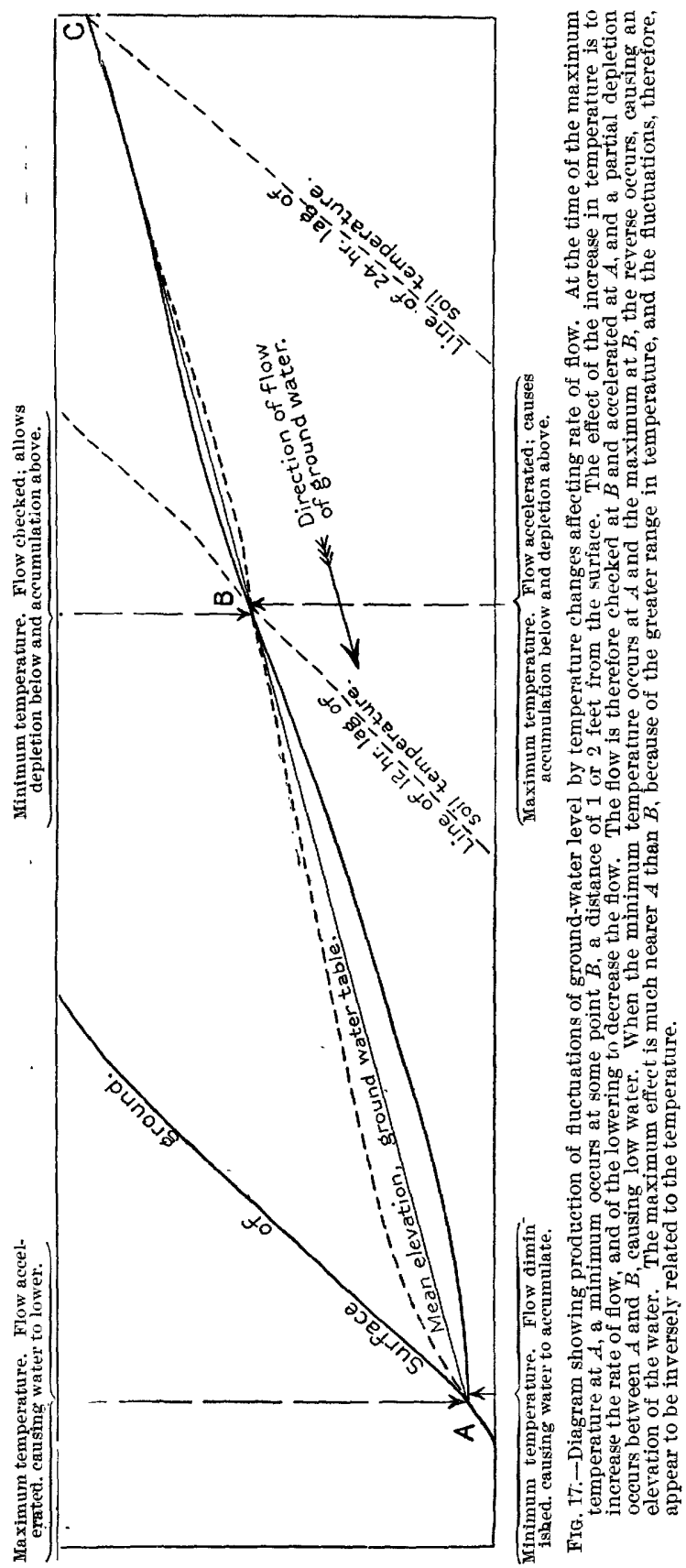
reached on but two occasions. The total annual variation from June 9, 1902, to May 51,1903 , was $16.2^{\circ} \mathrm{C}$. $\left(29.4^{\circ}\right.$ F. $)$. Similar results have been obtained by Callender at Montreal. $a$

As a result of this slow transmission of temperature, the temperature at the ground-water outlet may be at its maximum while a short distance away; where the water table is but a foot or two f "om the surface, the ground temperature may be at its minimum. Now, the rate of flow of water is greatly affected by temperature. Poisenille found that water at a temperature of $45^{\circ}$ C. flowed 2.5 times as fast under otherwise like conditions as water at $5^{\circ}$ C. $b$ This gives rise to the phenomena shown in fig. 17 .

There is thus produced a distinct and periodic fluctuation of the ground water, which is great near the ground-water outlet and decreases rapidly in amplitule as the distance from tha outcrop increases. The fluctuation is produced by an actual shifting of the water whereby the pressure conditions are constantly changed, and in this respect it differs from the Madison fluctuations (p. 54). It is this change in pressure that causes these fluctuations to show in the other walls, even to a depth of 500 feet. The same phenomencn of response to loading and relief from load is exhibited in some of the rainfall fluctuations

described above (p. 42) and in the sympathetic tidal fluctuations (p. 65).

a Callender, Hugh L., Proc. and Trans. Royal Soc. Canada for 1895, 2d ser., vol. 1, sec. 3, p. 79, fig. 4. $b$ Quoted by King, Nineteenth Ann. Rept. U. S. Geol. Survey, pt. 2, 1899, p. 82; see also Carpenter, L. C., Seepage and return waters from irrigation: Bull. Colorado Agric. Expt. Station No. 33, 1896, pp. $42-44$. 
These data suggest that the annual changes of the soil temperature may proauce a somewhat analogous effect, the warm summer temperature assisting in the $d$ pletion or lowering of the water near the ground-water outlets, and the cold winter temperature, by rendering the water more viscous, retarding the outflow. In one respect the result would be in the same direction as the annual ground-water fluctuations, and this is perhaps to be considered one of the minor factors. It would alsc tend to make the time of occurrence of the maximum and minimum of the yearly fluctuation earlier near the ground-water outlets than on the divides-or just th? condition observed on Long Island (p. 35).

\section{OBSERVATIONS AT SHERLOCK, KANS.}

Diurnal fluctuations due to temperature changes were observed by Mr. Fionry C. Wolff, at Sherlock, Kans., in 1904, while working under the direction of Prof. C. S. Slichter. $a \mathrm{Mr}$. Wolff reports that the wells are low in the evening and higl in the morning, and that there is no important time lag between wells where the water line is 6 inches below the surface and those where it is 3 feet below. In a few wells where the water level was about 3 feet from the surface, which were observed long enough to show the shape of the curve, the characteristics of the Madison crurve are shown-that is, there is a long fall and sudden rise.

\section{DIURNAI FLUCTUATIONS OF CACHE LA POUDRE RIVER, COLORADO.}

Carpenter has observed very regular diurnal changes in the height of Cache la Poudre River near Fort Collins, Colo. $b$ Here the high water occurs at from 4 to 6 a. m., the low water at $8 \mathrm{p} . \mathrm{m}$., and the extreme range of the daily change in river level noted was about 1 foot. The curves show the same characteristics as those observed by Wolff at Sherlock, Kans.; there is a long fall and a sudden rise, and they are therefore directly related to the temperature. Carpenter concludes that these fluctuations are due to differences in daily melting in the snow fields, and that the occurrence of the high water in the morning is due to the distance from the snow fields. While this is a very possible explanation, and in the writer's opinion it is probably the correct one, it is desirable to have the matter checked by other observations. If the fluctuations are purely due to daily waves moving down the river, due to melting snow, gages at other points should show the maximum and minimum at different times; if the fluctuations are due to variation in rate of grourd-water discharge and are analogous to those described above, the time will be the same at different points.

\section{REFERENCES RELATING TO FLUCTUATIONS PRODUCED BY TEMPERATURE CHATGES.}

Besides the references given above to the discussions of King, Slichter, and Wolff, it is desirable to add here the early reference of Pliny to fluctuating wells belonging to this class:

Pliny the Elder (Caius Plinius Secundus). Historia Naturalis, lib. 2, cap. 106 [Pliny's Natural History, Bostock and Riley's translation, Bohn's Libraries, vol. 1, 1887, pp. 133-134].

"In the island of Tenedos there is a spring which, after the summer solstice, is ful" of water from the third hour of the night to the sixth." "The fountain of Jupiter in Dodona . . . always becomes dry at noon, from which circumstance it is called 'The Loiterer.' It then increases and becomes full at midnight, after which it again visibly decreases." Hardouin notes that there is a similar kind of fountain in Provence called "Collis Martiensis." Theso fluctuations clearly belong to the class produced by temperature changes.

\section{FLUCTUATIONS PRODUCED BY RIVIRS.}

Rivers may produce fluctuations of the water level in wells in three ways: (1) By changing the height of the ground-water discharge; (2) by seepage or actual contributions- to the ground water, and (3) by transmitted pressure or plastic deformation.

$a$ The underflow of the Arkansas Valley in western Kansas: Water-Sup. and Irr. Paper No 153, U. S. Geol. Survey.

b Carpenter, L. G., Bull. Colorado Agric. Expt. Station No. 55, 1901, figs. $2-6$. 
FLUCTUATIONS PRODUCED BY GHANGES IN RATE OF GROUND-WATER DISGHARGE.

In regions where the sides of the channels are pervious and the ground water contributes to the stream flow, the water table, after a period of long drought, slopes regularly down to the water surface. If the stream rises throtigh causes not associated with local ground-water conditions, the ground-water table is found likewise to rise to a greater or less extent. This is accomplished in part by an outfow from the river and in part by the accumulation of the ground-water flow, which not so readily escape under the new conditions as under the old. If this new level were permanently maintained a complete readjustment would take place, and a line roughly parallel to the initial position of the ground-water table would be developed; and if there were no new outlets developed by this elevation of the ground water, wells at all distances would be similarly affected. Actually, however, the river is constantly changing; a series of waves of unequal height and duraticn, representing the high and low waters, are constantly traveling down every stream, and no stage lasts long enough for the establishment of a perfectly graded ground-water table, even were there no other factors involved. The result of this uncessing change is that the fluctuations are greatest near the river and become imperceptible at very short distances. This is due not only to the rapidity of the fluctuations in the river, but to the slow rate of outflow and accumulation.

Observations made by Hess $a$ along Aller River, near Celle, Germany, in 1866, give the values expressed in the table below:

Table showing lag of high-and low-water stages in wells along Aller River, behind high-and low-water stages in the river.

\begin{tabular}{|c|c|c|c|c|c|c|c|}
\hline \multirow[b]{2}{*}{ Test well No.- } & \multirow[b]{2}{*}{$\begin{array}{c}\text { Distance } \\
\text { from } \\
\text { river. }\end{array}$} & \multicolumn{2}{|c|}{$\begin{array}{c}\text { High water, Feb.- } \\
\text { Mar., } 1866 .\end{array}$} & \multicolumn{2}{|c|}{$\begin{array}{c}\text { Low water, Mar. } 7, \\
1866 .\end{array}$} & \multicolumn{2}{|c|}{$\begin{array}{c}\text { High water, Apr. 1, } \\
1866 .\end{array}$} \\
\hline & & $\begin{array}{c}\text { High wa- } \\
\text { ter in } \\
\text { well be- } \\
\text { hind high } \\
\text { water in } \\
\text { river. }\end{array}$ & $\begin{array}{c}\text { Rate per } \\
\text { day. }\end{array}$ & $\begin{array}{l}\text { Low water } \\
\text { in well be- } \\
\text { hind low } \\
\text { water in } \\
\text { river. }\end{array}$ & $\begin{array}{c}\text { Rate per } \\
\text { day. }\end{array}$ & $\begin{array}{c}\text { High water } \\
\text { in well be- } \\
\text { hind high } \\
\text { water in } \\
\text { river. }\end{array}$ & $\begin{array}{l}\text { Rate per } \\
\text { day. }\end{array}$ \\
\hline $1 \ldots$ & $\begin{array}{r}\text { Meters. } \\
47\end{array}$ & $\begin{array}{r}\text { Days. } \\
5\end{array}$ & $\begin{array}{r}\text { Meters. } \\
10\end{array}$ & Days. „• & $\begin{array}{r}\text { Meters. } \\
23.5\end{array}$ & ${ }_{4}^{\text {Days. }}$ & $\begin{array}{r}\text { Meters. } \\
12.5\end{array}$ \\
\hline $2 \ldots \ldots \ldots \ldots$ & 140 & 5 & 28 & $\mathbf{3}$ & 47.0 & 5 & 28,0 \\
\hline $3 \ldots .$. & 351 & 17 & 21 & 4 & 88.0 & 10 & 35.0 \\
\hline $4 \ldots \ldots \ldots \ldots \ldots . . . \ldots$ & 468 & 19 & 24 & 7 & 67.0 & $\ldots \ldots \ldots$ & $\ldots \ldots$ \\
\hline $5, \ldots \ldots \ldots \ldots \ldots \ldots$ & 584 & 21 & 28 & $\ldots \ldots \ldots$ & $\ldots \ldots \ldots$ & . & $\ldots \ldots \ldots$ \\
\hline
\end{tabular}

Observations made by Slichter in very porous gravels in western Kansas, at Garden, Sherlock, and Deerfield, while showing a more rapid transmission than those just indicated, give very marked time lags. The conditions here are different in the respect that the ground water does not materially add to the st"eam flow, and the rise of the water in the wells is due wholly to seepage. The slope of the water plane is not toward the river, but downstream, at a rate very nearly the same as that of the stream. At Sherlock the water plane on July 27, 1904, sloped gently to the river from test well No. 5 , but the water in test wells Nos. 2,3 , and 6 was lower than the river. Between 11 and 4 o'clock the river rose 1.6 feet, and then fell gradually. The beginning of the rise was felt in well No. 3, 400 feet north of the river, in less than two hours; in wells No. 2, 900 feet north of the river, and No. 5, 550 feet south of the river, in between three and four hours; in well No. 4, 1,000 feet south of the

a Hess, Beobachtungen über dasGrundwassers der norddeutschen Ebene. Z€itschr. des Architekten und Ingenieurvereins in Hannover, vol. 16, 1870, quoted by Soyka, Der Boden Leipzig, 1887, pp. 262267, figs. 23-25; and Gerhardt, Der Wasserbau, Leipzig, 1892, pp. 49-50, Pl. I, firs. 7, 8 . The diagrams given by Soyka and Gerhardt do not check with the values given in the text, and as the figures are clearly carelessly drawn the text values are reproduced here. 
river, in four hours. Well No. 6, 2,500 feet from the river, fell during the whole period of observation. The difference in time in the occurrence of the maximam is expressed in the following table:

Difference in time between high water in Arkansas River and wells on its banks, neas-Sherlock, Kans., July, 1904.

\begin{tabular}{|c|c|c|}
\hline $\begin{array}{l}\text { No. of } \\
\text { well. }\end{array}$ & $\begin{array}{l}\text { Distance } \\
\text { from } \\
\text { river. }\end{array}$ & Lag. \\
\hline 3 & $\begin{array}{l}\text { Feet. } \\
\quad \alpha 400\end{array}$ & $\begin{array}{c}\text { Hours. } \\
3-6\end{array}$ \\
\hline 2 & $\alpha 900$ & 12 \\
\hline 1 & $\alpha 500$ & 36 \\
\hline 5 & $b 550$ & $108+(?)$ \\
\hline 4 & $b 1,000$ & $108+$ \\
\hline 6 & b.2, 500 & $(c)$ \\
\hline
\end{tabular}

It will be noted that the most rapid transmission was toward the north, vhere the water plane sloped away from the river, while the slight rise of the water plane toward wells Nos. 4 and 5 produced a very marked retardation.

These observations seem to indicate that the rate of transmission is greater when the water plane slopes from the river than when it slopes toward it anc help to explain the great retardation observed at Celle. In no instance in this Karsas work were the effects of floods observed in wells at distances of more than one-fourth of a mile from the river.

In case there is open connection between the river and the well, such as might be afforded by limestone caves, changes in level may be felt at considerable distances with but very little time lag. Very rapid fluctuations would, however, be obliterated here, for the well would act very much as the still box used in tidal work, which consists of a large well connected with the ocean by means of a relatively small passage opening at some distance below the water surface. The wave action is entirely obliterated, because the water does not have time to flow in and out of the well in the period between fluctuations. The gradual changes of the tide are, however, exactly recorded. But direct cavernous connections between vells and waterways are rare, and generally river changes act through the interstices of the soil in the way observed at Celle and Sherlock or by transmitted pressure as described below.

\section{FLUCTUATIONS PRODUCED BX IRREGULAR INFILTRATION FROM RIVERS WITH FORIAILY IMPERVIOUS BEDS.}

Besides rivers which have pervious sides and into which the ground water is always free to flow or out of which the water flows whenever the river leve ${ }^{1}$ exceeds that of the ground water, there are many rivers which, under normal cond tions, so plaster their beds with fine silt that water is unable to flow either in or out. Nearly all rivers carrying large amounts of fine silt $a$ are normally in this condition, and it is thus that the water in many delta regions is able to fiow at heights above the surrounding land, and rivers in other regions flow at heights much above tha normal ground-water level.

Thus the Leitha at Katzelsdorf, near Wiener Neustadt, flows at a height of 10 to 70 feet above the level of the ground water at that place, the height deperding on

a For an example of the silting power of a elear stream see Freeman, John R.. Percolaticn through Embankments and the Natural Closing of Leaks, Boston Soc. Civil Eng., June $20,1888$. 
the stage of the ground water, although there is at all times considerable seepage. (PI. IX.)

The Rio Grande in a similar way flows from central New Mexico to the sea, always above the ground-water level.

When the rivers silt up their beds, where the water plane slopes down to the river and there is a tendency to discharge into the river, the silting develops an artesian head which causes the water to rise above the level of the river in wells sunk within the channel. Such occurrences have been reported by Salbach in the Elbe. a This Elbe occurrence may, however, be due to a sheet of clay not connected with the river-silt deposits of the present régime. During floods such rivers frequently scour out their beds and establish a connection between the surface and the underground waters. When the river is above the ground-water table, this leakage will raise the water level; when the reverse is the case, it may, by permitting a discharge of the artesian water, cause the water level in a near-by well to lower.

Slichter has found át Mesilla Park, N. Mex., that the greater part of the underflow in the valley is derived in this way from the flood waters of the Rio Grande. $b$ Preceding the flood of October 5,1904 , the ground-water level was s?veral feet below the river channel, although the river contained considerable water. The effect of the flood was well marked at well No. 7 , three-fourths of a mile from the river, but did not affect well No. 6, 1.3 miles from the river, in seventeen days The rate of transmission is evidently quite sinilar in this case to those given above.

Quite different from these slow rates of change in the ground-weter level due to river changes are the changes in the London wells ascribed by Clutterl "ick and Buckland $c$ to floods in Colne River at Watford, Hertfordshire. According to these observers a rise in the Colne produces a rise in the London wells, 15 miles distant, in a few hours. These floods are due to heavy rains and it seems much mor? probable that the observed rise is due to the weight of the rain on the local London area than to the transmitted pressure from a flood 15 miles distant. Fluctuations of this character due to rainfall have been observed at Lynbrook, N. Y. (p. 42), and no such rates of lateral transmiscion have been observed either from the river flood or tides, with the possible exception of the tidal wells at Lille, France (p. 64.) Certainly there is no evidence of such great underground caverns between Lille and the sea as this rate of transmission would require, though its very occurrence, if conclusively proven, would indicate some such connection.

\section{FLUCTUATIONS DUE TO A PLASTIC DEFORMATION PRODUCED BY VARYING VOLUMES OF WATER CARRIED BY RIVERS.}

The alternations of load due to the irregular waves, whose crests are the high-and low-water stages, which are constantly passing down every river, produce fluctuations anagalous to those produced by tides, thongh lacking their periodic character. They resemble also the sympathetic fluctuations produced in the 72 - and 504-foot wells at Lynbrook due to variations in load produced by rainfall and thermometric changes (pp. 43,58). The zone in which these fluctuations will bo distinctly reeognizable will be limited to a mile or two in the immediate vicinity of the river.

\section{REFERENCES RELATING TO FLUCTUATIONS OF THE WATER IN WELLS PRODUCED BY} RIVERS,

Btick Land, Dr. Min. Proc. Inst. Civil Eng. [vol. '2], 1812, p. 159.

Reports that wells in London rise in a few hours alter floods at Watiord, 15 miles distant.

Cuntтerbuck, James. Observations on the periodical drainage and replenishment of the subterraneous reservoir in the chalk basin of London: Min. Proc. Inst. Civil Eng. [vol. 2], 1842, pp. 156, $158 ; 1843$, p. 162 .

Same as under Buckland.

a Salbach (Baurath at Dresden, Saxony), Experiences had during the last, twenty-five years with waterworks having an underg round souree of fupply. Trans. Am. Soc. Civil Eng., vol. 30, ixg3; $p 311$.

$b$ Slichter, Charles S., Observations on the ground waters of Rio Grande Valley: Water-Sup. and Irr. Paper No. 141, U. S. Geol. Survey, 1905, p 27.

$c$ Min, Proc. Inst. Cavil Eng., 1812, pp. 15s, 159, 1843, p. 162. 
Fuller, Myron L. Notes on the hydrology of Cuba: Water-Sup. and Irr. Paper No. 110, U. S. Geol. Survey, 1905.

Records, on p. 189, fluctuations of spring level at Vento, Cuba, due to changes ir level of Almendares River, evidently acting through a free connection of large size in the limestone.

HARRIS, GILBERT D. Underground waters of south Louisiana: Water-Sup. and Irr. Paper No. 101, U.S. Geol. Survey, 1904, p. 14; Bull. Louisiana Geol. Survey No. 1, 1905, p. 4.

Discusses effect of Mississippi River on level of wells along its banks.

GerhardT, P. Der Wasserbau, vol. 1, pt. 1, 3 d eri., 1892, pp. 48-49. Gives Hess's observations on Aller River.

Slichter, Charles S. Observations on the ground waters of Rio Grand Valley: Water-Sup. and Irr. Paper No. 141, U.S. Geol. Survey, 1905, pp. 18, 25-28, 30.

Gives observations on effect of outflow from river on ground-water level at El Paso, Mesilla Park, and Berino.

The underflow of the Arkansas Valley in western Kansas: Water-Sup. and Irr. Paper No. 153, I. S. Geol. Survey.

Gives results of observations on the influence of floods in Arkansas River on the water level in wells at Garden, Sherlock, and Deerfield, Kans., in the summer of 1904.

SoYkA, IsIDoR. Die Schwankungen des Grundwassers: Penck's Geographische Abhandlungen, vol. 2 , pt. $3,1888$.

Chapter 3, "Die Beziehungen des Grundwassers zu den oberirdischen Wasserläufen," contains an excellent discussion of middle European conditions.

Thomassay, Raymond. Géologie pratique de la Louisiane, 1860.

Contains an entirely fanciful discussion of the seepage of the water from Mississippi River.

TODD, JAMES E. Geology and water resources of a yortion of southeastern South Dakota: V'ater-Sup. and Irr: Paper No. 31, U.S. Geol. Survey, 1900, P. 29: Bull. South Dakota Geol. Survey I'T. 2, 1898, p. 116.

Records that many deep wells have a greater discharge when Missouri River is high. and suggests that the increased hydrostatic pressure checks the leakage.

Veatch, A. C. Geology and underground water resources of northern Louisiana and southern Arkansas: Prof. Paper U. S. Geol. Survey No. 46.

Records fiuctuations of water level in artesian wells at Fulton, Ark., agreeing with stages of Red River. These are ascribed to pressure of river water acting at the outcrop of the waterbearing sands in river bed several miles from the town. This probably is a case of transmitted pressure, the blue clay over the water-bearing layer acting as a diaphragm and producing fluctuations in wells near the river.

\section{FLUCTUATIONS PRODUCED BY CHANGES IN LAKE LEVEI.}

Variations in lake levels of whatever cause produce fuctuations of the leve? in wells along their shores (1) by checking the rate of outflow when the ground water is draining freely into the lake and (2) by transmitted pressure and deformation as in ocean tides described below. The pressure of deep-seated waters might also 1 a slowly affected by the weight of the sediment deposited in the lake beds. This would tend to equalize itself by back flow, and is perhaps a factor of no great importance, except when considered for very long periods. King has, however, obtained a flow artificially by ordinary sedimentation in a tank. ${ }^{a}$

FLUCTUATIONS PRODUCED BY VARIATIONS IN THE OCEAN I.EVELTIDAL WELLS.

As partially indicated in the references on page 67 , wells and springs which fluctuate with the tide have been observed on nearly all coasts and under many different geologic conditions. These fluctuations are produced in three ways: (1) By transmission of pressure through open cavities or passageways affording a free communication between the wells and the ocean; (2) by a checking of the rate of discharge of the normal ground-water flow through porous beds freely connecting with the ocean; and (3) by a deformation of the strata due to the alternate loading and unloading of the tides. In this last case, instead of leakage being an important factor, as it is in the first two, the fluctuations are greater the more nearly complete the separation of the oceanic and ground waters. 
FLUCTUATIONS PRODUCED BY OHANGES IN RATE OF OUTFLOW.

The first two classes differ more in the rate at which the change takes place and the character of the zone of influence than in the manner in which it is produced. If the ocean level is raised the first effect is to check the velocity of outflow; but before any change occurs'in the level of near-by wells it is necessary that water accumulate at the point of observation by actually flowing in. This change, then, is clearly dependent on the same factors which influence the rate of flow, and in underground caverns where the velocity is a question of miles per day this accumulation will be rapid, there will be a relatively short lag, and the distance from the shore to which the rise can be propagated before the water begins to fall will be comparatively great. Its influence will, however, be restricted to wells along limited lines, following the course of the underground passageway. On the other hand, whon the water is flowing through the interstices of porous strata, where the motion is one of feet per day instead of miles, the accumulation will be slow, the lag proportionately greater, and the zone of influence, while not extending so far from the ocean, will perhaps occupy a larger area, because of its uniform distribution along the coast. When the ocean level falls the reverse will occur,

Where there is considerable velocity, as in a cavernous opering, the velocity of outflow retards the effect of the rising tide and hastens that of the falling tide and there is then, as in tidal rivers, a greater lag at low than at high water. When the outflow is slow, as from porous beds, the velocity is not sufficiont to exert a very great retarding influence.

The fluctuations in porous materials along the seashore are clearly the same in character and cause as those occurring under similar conditions along river courses (see p. 60), and the same great time lag is to be expected. The difference is only in the very regular periodic nature of the oceanic fluctuations. Nearly all the shallow: tidal wells noticed along the seacoasts belong. to this class. Snch are clearly the tidal wells $a$ reported near Bombay and along the Malabar coast; at Barren Island, in the Andaman Sea; at Perim Island, in the Red Sea; at South Foreland light-house, Kent; the shallow wells at Seagirt, N. J.; and perhaps the wells at Newton Nottage, Glamorganshire, Wales, and Ghepstow, Monmouth, England. At Perim Island, in shallow pits at a distance of 60 to 300 feet from the shore, the lag is such that the high water in the wells appears to agree with the low water in the ocean. A similar lag is reported in a well 14 feet deep and 400 feet from the riven at Chepstow. At Newton Nottage, where a shallow well 500 feet from the ocean was observed by Mandan, the lag is but three hours.

Experience has shown that wells which are sunk entirely in porous beds near the seacoast should have their bottoms about midway between high and low tide; if they are deeper there is generally an infiltration of salt water. Such wells are commonly dry at low tide, but frequently furnish good supplies of fresh water at high tide, at which time it is necessary to obtain all the water used for domsstic and other purposes.

Wells dependent on underground cavernous openings, such as required by the first case, are quite rare. The fluctuations of the Iceland springs, reported by Hallan de Roucroy, are perhaps connected with such open fissures, though any opinion from the data presented is but a hazard. Perhaps the most remartrable occurrence of tidal fluctuation is that reported at Lille in an artesian well at the citadel. These fluctuations, which amount to 0.415 meter, are referred by Bailly $b$ to the tides of the English Channel, 30 miles away, with a time lag of but eight hours. The only basis on which these fluctuations can now be explained is a supposition of a relatively open connection between the well and the ocean, which, it must be admitted, is a very unsatisfactory hypothesis. 


\section{TIDAL FLUCTUATIONS IN WELLS PRODUCED BY PLASTIC DEFORMATION.}

Besides the shallow wells, depending on ordinary porous surficial beds, there are, along and near the seacoast, many deep artesian wells which show tidal fluctuations. In many of these wells there are clearly no underground caverns involved, the water-bearing beds being ordinary porous strata in which the water flows through the small interstices at a rate to be expressed in feet rather than miles per day, and in which accumulation or depletion by simple fiowage will be correspondingly slow. There is, moreover, every reason to believe, in some cases where there are thick clay beds above the water-bearing strata, which are known to be continuous for many miles, that there are no near suboceanic outlets of importance. In case there is some distant outlet it is evident from the slow rate of change shown in the examples given above, where there was a sudden increase or decrease in the volume of river water ( $p$ p. 60,61), that the fluctuation produced by a simple checking or hastening of the rate of outflow could be propagated but a short distance, and that a long period of time would be necessary for even that.

There is, however, in the case of waters under artesian head a new factor introduced which is of very great importance. The pressure of the artesian water exerted against the retaining cover, which may be assumed at present to be clay, tends to elevate it, thus placing the clay under an upward stress. The addition of any weight on the surface tends to disturb the equilibrium. If there is no outlet and the weight is applied uniformly, the additional weight can not change the position of any portion of the mass, except to the very slight degree of the elastic compressibility

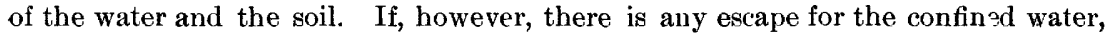
such as would be afforded by a well tube, the mass will yield and the water be forced up in the tube. Were the clay layer perfectly elastic, or in the condition of a stretched elastic membrane above a perfectly mobile body, there would be no time lag, and the water in the well would exactly follow the fluctuations of the ocean waters; but the clay is not to be regarded as an elastic diaphragm, and the water-bearing sand is not a perfectly mobile body; moreover, for such a deformation to be felt in a well water must be transferred from one point to another, and this involves a time element. The deformation is essentially a plastic one; the clay yields to the superposed weight and the water is lifted in the well, but if there were no pressure from below the clay could not return to its original position. In the case of tides along the coast only the portion of the clay layer under the ocean is loaded, and that loading is a progressive one from a distant point toward the shore. The effect is a deformation in which the clay layer is depressed under the ocean and elevated under the land. When the weight is removed the artesian pressure tends to reestr.blish the old conditions of equilibrum, and the clay layer is lifted under the ocean and sinks under the land.

If the artesian pressure is high, compared with the tide when the ocean water commences to fall after high tide, this pressure lifts the clay quickly and thus tends to shorten the high-tide lag in a near-by well; as the tide falls the high pressure enables the clay to follow the tide closely; at low tide the artesian pressure is clearly in the ascendancy and the clay still rising in the ocean area. As the tide begins to rise it must overcome this artesian pressure before any deformation occurs, and the rising curve in the well therefore lags more behind the tide than the falling curve. Under such conditions the high-tide lag is less than the low-tide lag. . Conversely, when the artesian pressure is low compared with the tide, at high tide the feeble arterian pressure but slowly lifts the clay weight and the lag is long; at low tide, when the clay diaphragm is high, the greater tidal weight quickly overcomes the feeble resistance of the artesian water and the lag is short; it mav then happen that the low-tide lag will be less than the high-tide lag. $a$ It is evident that between the twc extremes thus

a This plastic deformation should not be confused with the elastic deformation of the earth which Darwin has considered in his calculations of the effect of tides on seacoasts. He assumas that the IRR $155-06-5$ 
indicated there are all possible variations, and that the thickness and plasticity of the beds above the water-bearing layers are important modifying factors. The fluctuation in a well in such cases does not furnish an exact measure of the amount of deformation; it furnishes only a fair indication of the variation in pressure at the particular point at which the well is sunk.

The maximum effect is felt at the seacoast near low-tide mark and gradually decreases inward, disappearing in a few miles. It is less if there is leakage from subocean springs, for in such cases the escape of the water decreases that available for the elevation of the water in the tube.

On Long Island the tidal fluctuations observed in the wells at Huntington, Oyster Bay, Long Beach, and Douglaston are clearly of this character, all depending more on the deformation of the overlying layer through tidal load than on changes of discharge in leakage. At Huntington (p. 10), Oyster Bay (p. 13), and Douglaston (p. 25) the lag is greater at low than at high tide, as would be expecter from the great head and shallow depths, while at Long Beach, where the head is low, the water-bearing sand fine, and the thickness of overlying strata great, the reverse is true (p. 19). The Oyster Bay observations give the following values:

Summary of observations on tidal wells at Oyster Bay, N. Y.

\begin{tabular}{|c|c|c|c|c|}
\hline Well. & Depth, & $\begin{array}{c}\text { Distance } \\
\text { from ordi- } \\
\text { nary high } \\
\text { tide. }\end{array}$ & $\begin{array}{c}\text { Low-water } \\
\text { lag. }\end{array}$ & $\begin{array}{c}\text { High-water } \\
\text { lag. }\end{array}$ \\
\hline Casino......$\ldots \ldots \ldots$ & $\begin{array}{r}\text { Feet. } \\
93\end{array}$ & $\begin{array}{c}\text { Feet. } \\
\text { In water. }\end{array}$ & $\begin{array}{r}\text { Minutes. } \\
12.6\end{array}$ & $\begin{array}{r}\text { Minutes. } \\
8.0\end{array}$ \\
\hline Burgess .......................... & 155 & 50 & 33.4 & 24.7 \\
\hline Lee...$\ldots \ldots \ldots \ldots$ & 188 & 100 & 58.0 & 42.0 \\
\hline Underhill $\ldots \ldots \ldots \ldots \ldots \ldots$ & 114 & 500 & 75.6 & 71.8 \\
\hline
\end{tabular}

It will be noticed that the lag here increased with the distance from the shore, and that the low-water lag increased more rapidly with depth than the high-water lag. The canse of the very small difference between the high- and low-water lags in the Underhill well, the one farthest from the shore, is not clear, but it is apparently related to the lessening of the tidal influence with the increasing distance.

The Long Beach well is affected both by the tide in the ocean and in the channels behind it, the curve being, as would be expected, a simple resultant of the two stresses. Because of the shallow bars at the openings the irregularity in the height of the inner low tide is less than in the ocean, and the effect of this difference is shown in the greater regularity of the low-tide heights in the well than in the ocean (PI. IV, p. 20). Here the high-tide lag is one hour and nineteen minutes and the low-tide lag forty minutes, when compared with the ocean, while compared with the tide behind the bar the high-tide lag is practically nothing and the low-tide lag is nearly two hours.

To this same class belong nearly all the deep artesian wells along the seacoast which fluctuate with the tide. The phenomenon observed is the result of actual deformation, and the occurrence of tidal fluctuations in deep wells does not, as has been commonly supposed, prove a connection between the water-bearing strata and the ocean. Examples of this type are afforded by the deep wells slong the New Jer-

earth has an elasticuty equal to twice that of the stiffest glass, and the elastic compression produced by loading a sphere of such material of the same size as the earth with a tide of 5 feet is calculated on the supposition that the ocean is in the shape of a narrow canal. According to this the tides on the Atlantje coast may cause the land to rise and tall as much as 5 inches. See Darwin, G. H., On variations in the vertical due to elasticity of the earth's surface: Brit. Assoc. Rept., 1882, p. 388; Phil. Mag, 5th ser., vol. 14, 188:, pp. 409-427. The Tides, Boston and New York 18:s, pp. 139-143, quoted by Milne, J., Ńature, vol. 38, 1883, p. 367, Seismology, London, 1898, pp. 236-237. 
sey coast, the wells at Pensacola, Fla., the deep wells at Greenwich Hospital, London, and the wells along the Lincolnshire and Yorkshire coasts.

Shelford $a$ has presented a very clear diagram of the conditions on the Lincolnshire coast. This shows overflow springs occurring at the top of a porous layer and the base of an impervious one, and the relation between ordinary overflowing and tidal wells, all depending on the same strata. Here, as is almost universally the case, the tidal wells occur only on the shore, and the wells 2 and 3 miles inland are not affected. In explaining the phenomenon Shelford supposed that the water found an outlet in Silver Pit, a deep hole in the ocean bed about 18 miles from the coast, which he has represented in his drawing as the ground-water outlet, and that ehanges in level in the discharge produced the tidal fluctuations. Such a simple change in the rate of discharge could affect the wells 18 miles distant only if there were a large open cavernous connection. That there is no such cavern is shown by the fact that the effect diminishes very rapidly in passing inland, entirely dying out in 2 miles. There is no reason why the effect should be propagated 18 miles to the coast and then suddenly cease, when tidal wells of the same character penetrating a thick clay bed and obtaining water in the upper porous layer of the chalk occur along the whole Lincolnshire and Yorkshire coast. In many cases springs near the coast, deriving their supply from the water beneath the clay, are likewise tidal. The cause of this phenomenon in the Bridlington Quay wells, Yorkshire, was correctly given by Inglis in 1817 . He recognized in the clay layer a moving diaphragm affected by the tidal pressure from above and the artesian pressure from below.

\section{REFERENCES RELATING TO TIDAL FLUCTUATIONS IN WELLS AND SPRING".}

ANonymous. London A thenæum, August, 1860; Jour. Franklin Inst., vol, 72, 1861, pp. 309-310.

States that tides in wells near the sea are universal, and records their occurrence about Bombay and along the Malabar coast wherever the material dug through is porous. Wells dug in trap rock are not tidal.

BaILly. Rapport sur les variations observées dans la dépense du puits artésien de l'hópital militaire de Lille et dans les hauteurs de la colonne d'eau quand on a interrompn l'écoulement: Comptes renuus, vol. 14, 1842, pp. $310-314$.

Gives observations showing that fluctuations, having a range of 0.415 meter, are claarly tidal and occur eight hours behind the tide on the adjacent coast between Dunkerque and Calais. Reports that tidal wells also occur at Noyelle-sur-Mer, Département de la Somme, and at Fulham, London, England.

Braithwaite, Fredrick. Min. Proc. Inst. Civil Eng., vol. 9, 1850, p. 168; vol. 14, 1855, pp. 507-522.

"At Greenwich Hospital, London, the land springs ebb and flow 2 feet 6 inches, the sand springs, 3 feet, and the chalk springs, 4 feet 6 inches every tide." The total depth of the chalk well referred to is 149 feet.

Christie, JaM ES. Jour. Franklin Institute, vol. 101, 1901, p. 193.

Reports fresh-water well near shore which fluctuates with the tide.

Clutterbuck, James. Min. Proc. Inst. Civil Eng., vol. 9, 1850, p. 170.

Explains tidal fluctuation in wells on basis of leakage between high- and low-tide marks.

Min. Proc. Inst. Civil Eng., vol. 14, 1855, pp. 510-511.

Wells at Ramsgate, England, are sunk to half-tide level. These begin to fall at half tide, are dry at low tide, and begin to rise at half tide on the flood.

Min. Proe. Inst. Civil Eng., vol, 19, 1860, p. 33.

Reports that wells at Portsmouth, England, are tidal, and concludes that this proves a free connectron with the sea.

Desaguliers, Rev. J. T. An attempt to account for the rising and falling of the water of some ponds near the sea, etc. Trans. Phil. Soc. London, No. 381, vol. 33, 1724, p. 132; Trans. Phil. Soe. London from 1665-1800 (abridged), vol. 7, 1809, pp. 39-41.

Reports well at Greenhithe in Kent, between London and Gravesend, which appears to fluctuate inversely with the tide. This he explains by imagining a natural siphon.

Dovglas, James Nichols. Min. Proc. Inst. Civil Eng., vol. 47, 1879, p. 88.

Chalk well at South Foreland light-house, Kent, England, 283 feet from face of cliff, 280 feet deep, with bottom level with half tide, has a peculiarity common to many wells of this region in that it is dry at low tide and flled with pure spring water at high tide. 
Frazer, Persifor. Notes on fresh-water wells of the Atlantic beach: Jour. Franklin Inst., 1890, vol. 130 , p. 231.

Reports weil at Sea Girt, N. J., 20 feet deep, which rises and falls with tide in ocean 150 feet distant.

HALLAN DE Rovcroy. Comptes rendus, vol. 12, 1841, pp. 1000-1001.

States that well at Lille, France, shows tidal fluctuations.

Hutton, Capt. F. W. Trans. and Proc. New Zealand Inst., 1895, vol. 28, 1896, p. 655. States that artesian wells at New Brighton are affected by the tide.

IngLis, Gavin. On the cause of ebbing and flowing springs [at Bridlington, Yorkshire]: Phil, Mag., vol. 50, 1817, pp. 81-83.

"When the recess of the ocean lessens the pressure upon the upper surface, the hydraulic pressure on the under stratum must raise the whole mass in proportion as the force is superior to the resistance. The return of the tide brings with it the weight and altitude of its mass of water and acts on the flexibility of the clay as a pressure would on a hydraulic blowpipe."

KING, Franklin H. Fluctuations in the level and rate of movement of ground water: Bull. U. S. Weather Bureau No. 5, 1892, pp. 52-53.

Suggests that tidal fluctuations may be produced in wells by coastal deformation.

MaNDAN, H. G. Note on ebbing and flowing well at Newton Nottage [Glamorganshire, Wales]: Abs. Proc. Geol. Soc. London, 1898, pp. 85-86; Nature, vol. 58, 1898, pp. 45-16.

Shallow well 500 yards from shore ebbs and flows with the tide; lag about three hours.

MALLET, F. R. Ebbing and flowing wells: Nature, vol. 58, 1898, p. 104.

Shallow wells in volcanic ash on Barren Island, Andaman Sea, show tidal fluctuations clearly due to retardation of leakage.

MCCALLIE, S. W. A preliminary report on the artesian-well systems of Georgia: Bull. Geol. Survey Georgia No. 7, 1898, p. 112.

Reports three artesian wells at Tybee Island, near Savannah, Ga., 240 feet deep, one of which is affected by the tide.

Moore, H. C. A well intermitting inversely with the ebband flow of the tide: Trans. Woolhope Naturalists Field Club, 1892, pp. 23-24; Jour. Manchester Geol. Soc., vol. 10, 1894, pp. 223-224.

Well at Chepstow, Monmouth, fluctuates inversely with the tide. Shallow pits on Perim Island, Straits of Bab el Mandeb, Red Sea, 20 to 100 yards from shore, are full of fresh water at low tide, empty at high tide; explained on basis of time required for filtration.

Pearson, Rev. W. Observations on some remarkable wells near the seacoast at Brighthelmstone and other places contiguous. Jour. Nat. Phil. Chem. Arts, vol. 3, 1802, pp. 65-69.

States that shallow wells at Brighton fluctuate with the tide, but with a lag of two hours. He ascribes the fluctuation to retardation of leakage.

Pliny the Elder. (Caius Plinius Secundus.) Historia Naturalis, lib. 2, eap. 106: (Pliny's Natural History, Bostock and Riley's translation, vol. 1, 1887, pp. 134-135).

"There is a small island in the sea opposite the river Timavus, containing warm springs which increase and decrease at the same time with the tide of the sea."

Riviere. Comptes rendus, vol. 9, 1839, p. 553.

Spring at Givre, canton Montiers-les-Maux, fluctuates with tide.

RoBert, E. Comptes rendus, vol. 14, 1842, pp. 417-418.

Reports that springs near Buder, Olafsen, and Paulsen, Iceland, ebb and flow with the tide.

RoBERTS, IsA AC. On the attractive influence of the sun and moon causing tides . . . in the underground water in porous strata: Rept. Brit. Assoc., 1883, p. 405; see also Proc. Liverpool Geol. Soc., vol. 4, pt. 3,1881 , pp. 233-236.

Reports that in a well sunk in Triassic sandstone in which the water rose 60 feet above sea level, autographic records showed solar and lunar tides. (See p, 69.)

'SHelFo RD, W. Min. Proc. Inst. Civil Eng., vol. 90, 1887, p. 68.

Describes wells 200 feet deep, on the North Sea, near Louth, Lincolnshire, which fluctuate 3 feet with spring tides.

SinCLAIR, W. F. Ebbing and flowing wells: Nature, vol. 58, 1898, p. 52.

Describes well at Alibag, near Bombay, in sand dunes about 25 yards from high-tide mark, which fluctuated with the tide after heavy rains when the ground water level was high. Tide in well occurred later than that in ocean.

STORER, Dr. JOHN. On an ebbing and flowing stream discovered by boring in the harbor of Bridlington [Yorkshire]: Phil. Trans., vol, 105, pt. 1, 1815, pp. 54-59; Phil. Mag., vol. 45, 1815, pp. 432436.

S., W. On ebbing and flowing springs: Phil. Mag., vol. 50, 1817, p. 267.

States that wells near Hull under conditions similar to those at Bridlington are not tidal.

Tradtwine, J. C., jr. Jour. Franklin Inst., vol. 51, 1901, pp. 193-194.

Explains tidal wells on basis of free discharge in ocean, as from an open tube; changes in pressure at discharge change water level in wells as if they were piezometers al ang a conduit.

Tribus, L. L. Trans. Am. Soc. Civil Eng., vol, 30, 1893, p. 695.

Mentions tidal fluctuations in wells at Pensacola, Fla., $1 \frac{1}{2}$ miles from the shore front, 4 to 6 inches in diameter, and from 60 to 280 feet deep. Water rises 16 to 17 feet above sea level and 
fluctuates 6 to 10 inches daily with the tide. He supposes, therefore, that they tap subterranean rivers which have free connection with the ocean. Note: The tides at Pensacola are rather irregular, with a small semidiurnal and large diurnal value, and it is quite possible the.t a portion of the fluctuation observed is due to barometric and thermometric cbanges.

Vermeule, C. C. Water supply for wells: Ann. Rept. New Jersey Geol. Survey for 1898, 1899, p. 163.

States that many wells along the coast of New Jersey show tides corresponding in period, but not in time of occurrence, with the tides of the ocean, and with a smaller range.

Woop, JAMES G. Jour. Manchester Geog. Soc., vol. 10, 1894, pp. 237-239; Abs. Proc. Geol. Scc. London, 1898, p. 86.

Reports well near that described by H. C. Moore (see above), and snggests that well is fed by water coming along fault, which passes under the river; that at high tide this faul, is closed, cutting off supply, and at low tide opens again, allowing an infux; and that therefore well fluctuates inversely with tide. '(Note: A simple leakage would, on account of slow propagation of change, explain the phenomena quite as well, and more naturally.)

Woolman, Lewis. Artesian wells in New Jersey: Ann. Rept. New Jersey Geol. Survey for 1898, 1899, pp. $76,78,79$.

Records that the height of water in many artesian wells along the New Jersey coast, fluctuates with the tide. At Ventor fluctuations were noted in a well 813 feet deep, which hac a range of $7 \frac{3}{4}$ to $14 \frac{1}{2}$ inches, and a lag of approximately forty-five minutes. Similarly at Avalon, in a well 925 feet deep, the fluctuation observed had a range of from $10 \frac{1}{2}$ to $15 \frac{3}{4}$ inches.

Young, Rev. G. and J. Bird. A Geological Survey of the Yorkshire Coast. $4^{\circ}$. Whitby, 1822; $2 d$ ed., 1828.

Ebbing and flowing springs, Bridlington, pp. 22-24; intermittent springs, pp. 27-28.

\section{TIDES IN THE GROUND WATER PRODUCED BY DIREC'T SOLAR AND} LUNAR ATTRACTION.

The ground water has not an extended level surface like the ocean, where the tides range from nothing to 50 feet, or even the Great Lakes, where the tidal fluctuation is but a few inches. The ground-water table is comparatively level only over areas which are but a fraction of the size of the Great Lakes, and direct groundwater tides would be of extremely small size. It seems quite unlikely, therefore, that the fluctuations in the Maghull (Liverpool) well are due to direct solar and lunar attraction, as Roberts $a$ suggests, but, as King $b$ has already pointed out, are rather to be ascribed to the action of the ocean tides on the near-by coast.

\section{FLUCTUATIONS DUE TO GEOLOGIC CAUSES.}

In regions of abundant rainfall the ground-water table is but a subdued reffection of the surface topography, and any changes in the topography will therefore change the position of the ground-water table. If a stream valley is filled by sedimentation, the ground water is raised over the whole tributary area up to the grocnd-water divide; if the stream valley is eroded, the water level is in like manner lowered. Similarly, if a lake is produced by a landslip or destroyed by the erosion of its outlet, or the ocean level is changed by orographic movements, the ground-water table likewise is changed. . To these broad generalizations certain exceptions are to be mentioned. If a river is intrenched in an impervious layer overlain by porous strata, it is evident that the position of the impervious bed in the bank, when the water level in the river is below it, is the factor which determines the position of the groundwater table. A stream may thus lower its bed without affecting the adjacent ground water. Examples of this kind are found in the Isar at Munich and the S-lzach at Salzburg, both of which have deepened their beds in recent times, due to regulating works, without lowering the adjacent ground water, because the deepening was entirely in impervious material. $c$

Solution and deposition by percolating waters may cause a gradual depression or elevation of the water level; solution, by increasing the porosity and consequent rate of flow, will enable quite a quantity of water to escape along certain lines and so lower the water level; deposition, in an opposite way, will raise it. 
In regions where the rainfall is low and the ground-water table is below the level of the rivers changes in topography naturally have little effect, except where the erosion is sufficient to cut the ground-water table. Generally ir such regions the rivers contribute to the ground water by seepage, and the amornt so contributed becomes small when the conditions are favorable for the depositior of silt with which the rivers plaster up their beds. During flood periods the rivers scour out the silt and again allow the percolation of water.

Earthquakes may produce fluctuations due to several causes: Small fluctuations may result directly from the earth's tremors; a deformation without faulting may produce changes in pressure; and faulting may make new ground-water outlets which will cause the water in neighboring wells to rise or fall according to their relation to the faulting.

Geyser phenomena may produce both periodic and irregular fluctuations of the water level, and Slichter has suggester that the reculiar periodic fluctuations at Urisino Station, New South Wales (p. 76), may be due to such a cause.

In this connection it inay be well to refer to the hypothetical siphon, or Tantaluscup arrangement, which the old philosophers gave as an explanation of intermittent springs, ${ }^{a}$ a theory which has survived in Houston's Physical Geography, a work still used in the high schools in some parts of this country. $b$ From a geologic standpoint the existence of such a siphon arrangement as this theory postulates may be regarded as almost impossible because of the difficulty of finding an air-tight passage. The fluctuations are now known to be due in many cases to causes not understood at the time this hypothesis was advanced, and in the light of our present knowledge an intermittent spring depending on a natural siphon for its action would be regarded as a most exceptional phenomenon. It would be necessary to to more than prove that a spring or well ebbs and flows to establish the existence of such a siphon.

\section{FLUCTUATIONS PRODUCED BY HUMAN AGENTIES.}

\section{EFFECT OF SETTLEMENT, DEFORESTATION, AND CULTIVATION ON THE LEVEL OF WATER IN WELLS.}

It is well known that many hillside springs throughout the entire eastern United States which furnished water when the country was first settled are now dry, that large areas of former marsh land are now in cultivation, and that streams on which boats plied in the early days are no longer navigable. The rainf $x$ ll records do not indicate that there have been any radical climatic changes, and the changes are clearly the result of human occupation. $c$

Part of this is due to the fact that large areas have been artificially drained by tiles, ditches, or absorption pits; beaver rlams and other stream obstructions, such as the Great Red River Raft, have been removed, with the consequent drainage of greater or less areas." Some of the hillside springs have merely been buried as the soil washed in from the surrounding lands, while others have been affected by the drainage of the lower lands.

Different kinds of vegetation use different amounts of water ${ }^{e}$ and affect the surface

$a$ See Regnault, Père, Phil. Conversations, vol. 2. conversation 6: Dechales, Tract. 17 de Fontibus Naturalibus, etc.; Desaguliers, Kev. J. T., Trans. Phil. Soc. London, No. 384, vol. 33, 1724 (abridged edition Trans. 1665-1800, vol. 7, pp. 39-41); Atwell, Joseph, Trans. Phil. Soc. London, No. 424, vol. 37, 1732 (abridged edition Trans. 1665-1800, vol. 7, pp. 544-555).

$b$ For a more recent suggestion of the same theory, wee Knightly, T. E., Geol. Mag., n. s., decade 4, vol, 5,1898 , pp. $333-334$.

$c$ See, in this connection, King, Franklin H., Bull. U. S. Weather Bureau No. 5, 1892, p. 42; Lane, Alfred C., Water-Sup. and Irr. Paper No. 30, U. S. Geol. Survey, 1899, pp. 54-55.

$d$ Prof. Paper U. S. Geol. Survey No. 46, 1906.

$e$ The literature on the amount of water transpired from plants and evaporated from the earth under different conditions is very extensive, but the results are neither readily comparable nor readily applicable to natural conditions, because of the differing and in many cases unnatural conditions under which these experiments have been tried. For a review of the literature, see Harrington, M. W., Review of forest-meteorology observations, and Fernow, B. E, Reiation of forest to water supply; Bull. Bureau of Forestry, U. S. Dept. Agric. No. 7, 1873; Lueger, Ot to, Die Wasserversorgung der Städte: Der städtische Tiefbau, Bd. II, pp. 176-177, 196-205, bibliography, pp. 143-161; Wollny, Ewald, Expt. Station Record, vol. 4, 1893, pp. 531-533; King, F. H., The Soil, New York, 1895, Drainage and Irrigation, New York, 1899. 
evaporation in different ways, and a change in the plant covering or crop over large areas may clearly result in a broad elevation or lowering of the water level. Simiiarly, certain methorls of cultivation conserve more moisture than would find its way into the ground under certain natural conditions, while others allow large quantities to flow off the surface. Fertilizers and manures affect the rate of percolation in different ways; some greatly hasten and others retard the percolation of the soil water. The relation of cultivation to the position of the ground water is therefore rery complex, and it is clearly possible to have different results on adjacent fields. In regard to the effect of forested areas on percolation it should be pointed out, on the one hand, that (1) a portion of the rain water, varying from 8.5 to 59 per cent $a$ of the yearly rainfall, is caught in the crowns of the trees and is evaporated without reaching the ground; (2) the absorption capacity of the forest litter and moss is great, and water can be contributed to the ground water only after this is saturated; vhile the evaporation from this surface is slow, it is to be considered evaporation from a saturated surface, and the net result may be greater than from a region where the water sinks rapidly into the ground; (3) the old litter or humus is, according to th experiments by Riegler, Ebermeyer, and Wollny, practically impervious, and, rhile the fresh litter mav absorb large quantities of water, the impervious humus or rotted litter prevents the water from reaching the ground water; $(4)$ the roots of tha trees in some cases draw from ground water that is entirely out of the reach of ordinary field plants. Moreover, the direct observations of Ototzky ${ }^{b}$ and Henry and Tolsl y $c$ yield the positive result that in Russia and France the level of the ground water is decidedly lower under forests than under cleared land. The results of Ototzky's observations are summarized in the Experiment Station Record in the following words:

This is a translation from the Russian giving the results of a hydrological survey in the steppes region. The conclusion is reached that, physico-geographical conditions being the same, the level of ground water is lower in forests than in adjacent steppes or in general in neighboring open spaces. The level falls as forests are approached, the fall sometimes being very sudden, and it is more marked in case of old forests than new.

On the other hand, it should be pointed out that the stream flow from forested regions is more constant than from unforested ones, $d$ and as this is to be considered as due to ground-water phenomena it indicates a greater percolation.

On the plains, groves and hedgerows by acting as wind breaks tend to elevate the water level by decreasing the surface evaporation.

It is well known to agriculturists that it is possible to cultivate the soil so that the evaporation will be greater than under natural conditions or so that the moisture will be conserved. It is thus possible to either increase or decrease the ground water by cultivation. In the semiarid region of the Middle West, where the rainfall is light, the secret of the so-called "dry or arid farming" is to so prepare the soil as to insure the percolation of all the rain water or of a very large percentage of it, and to prevent its escape by evaporation. To accomplish this various methods of subsoiling, subsurface rolling, and surface mulching, either by pulverizing the soil or by the addition of straw or manure, have been employed, in some cases with marked success. I am informed by Prof. Charles S. Slichter that in western Kansas, where the Campbell system is employed, the ground water has in places been raised several feet by the increased percolation.

a See Bull. Division of Forestry, U. S. Dept. Agric. No. 7, 1893, pp. 100-101, 130-131, and references therein given; also Lueger, Wasserversorgung der Städte, p. 197.

b Ototzky, P., Ann. Sci. Agron. 1897, vol. 2, No. 3, pp. 455-477, pls, 2; review, Expt. Station Record, vol. 9,1898, p. 1041 .

c Henry, E., and Tolsky, A., Ann. Soc. Agron. 1902, vol. 3, No. 3, pp. 396-422; review, Expt. Station Record, vol. 15,1903 , p. 125

dsee Bull. Division of Forestry, U. S. Dept. Agric., No. 7, 1892, pp. 158-170; Manson, Marsfen, Comparison of low-water discharge from a timbered with that from a comparatively timberless area: Water-Sup. and Irr. Paper No. 46, TT. S. Geol. Survey, 1901, pp. 46-47. 


\section{EFEECT OF IRRIGATION.}

Irrigation, almost without exception, raises the ground-water level, and in regions where there is no natural ground-water outlet so placed that it furnishes a sufficient natural escape for the underflow, elaborate systems of tiling and primping are necessary to keep the water level from reaching the surface in the lov places and converting them into marshes or alkali flats. Carpenter reports that, in the Cache la Poudre Valley, Colorado, the water level has been raised 20 to 40 feet. $a$ The effects of irrigation in the King River Valley, Califormia, are shown in Water-Supply and Irrigation Paper No. 58, Pl. XXVI.

On Long Island only limited areas have so far been irrigated, but these bid fair to rapidly increase. On account of the very porous character of the soil and the fact that all the water used must be obtained from the ground water of the region involved, there is no danger of serious raising of the ground-water level; indeed, the net result here of extreme irrigation, which would have to be done by pumping, would be a lowering of the ground-water level to the extent of the added loss by evaporation and plant transpiration. When the water for irrixation is supplied wholly from springs, as it is at one or two points near Flushing, or where supplied from the city waterworks, as at Elmhurst, $b$ the result is a local raising of the groundwater level

\section{EFFECT OF DAMS.}

In regions where the ground water is tributary to the stream channels the effect of the ponding of streams, except where the material of the bed of the reservoir is entirely impervious, is to raise the ground-water level. As the pond or reservoir is relatively permanent, the ground water generally has time to adjust itself to the new conditions, and an elevation is produced which is persistent as long as the reservoir lasts. Thus on Long Island, where dams were built in all the little streams at an early day, the effect has been to abnormally raise the ground-water level over considerable areas.

In mill ponds of this character the use of the water during the day and the accumulation during the night give rise to a periodic fluctuation of the water in the wells along their banks which tends to accentuate the temperature effect.

In regions where the ground-water table is below the stream, pording will increase the leakage, though this may naturally check itself in time by the deposition of silt and colloidal material.

\section{EFFECT OF UNDERGROUND WATER-SUPPLY DEVELOPMENTS.}

Underground water is developed for water supply in one of frur general ways: (1) By subsurface dams, (2) by infiltration galleries, (3) by pumping from single wells or groups of wells, and (4) by flowing wells.

\section{EFFECT OF SUBSURFACE DAMS.}

In regions where there are valleys with impervious sides filled with porous material a dam across the valley will pond this underflow and force it to the surface. This has been employed in many regions of the West where dry stream beds with considerable underflow abound. The effect of such a structure on the ground-water level is shown in Water-Supply and Irrigation Paper No. 67, Pls. 'T, VII.

\section{EFFECT OF INFIITRATION GALIERIES.}

Infiltration galleries may either raise or lower the ground-water level. When constructed along the line of contact of a pervious and impervious bed they may act in

a Carpenter, L. G., Seepage or return waters from irrigation: Bull. Colorado Expt. Station, No. 33, 1896, p. 4 .

b Bull. Office Expt. Stations, U. S. Dept. Agric., No. 148, 1904. 
a way analogous to a subsurface dam. Where deep in pervious layers they offer a new outlet at a lower. level than the natural one, and so depress the water plane. This effect is the same as that in a pumped well, except that here the cone of depression is greatly lengthened in one direction.

\section{EFFECT OF PUMPTNG.}

The first effect of pumping is to develop a more or less symmetrical cone of depression, of which the well is the center. The steepness and slope of the cone cepend on such factors as the porosity, rate of flow, rate of pumping, and uniformity of soil. The effect of such a depression in the porous material on Long Island is to lower the water in adjacent wells and drain the near-by ponds and marsh areas. $a$

The effect of this lowering of the water table has a marked effect on the stream flow on Long Island, as is shown by the following table, compiled by L. P Ward:

Elfect of ground-water pumping in diminishing stream flow, from $18 \% 3$ to 189G, in the old watershed of the Brooklyn waterworks, comparing five-year periods. a

\begin{tabular}{|c|c|c|c|c|c|c|}
\hline \multirow[b]{2}{*}{ Period. } & \multirow[b]{2}{*}{$\begin{array}{c}\text { Aver- } \\
\text { age } \\
\text { annual } \\
\text { rain- } \\
\text { fall. }\end{array}$} & \multirow{2}{*}{\multicolumn{2}{|c|}{$\begin{array}{l}\text { Average annual } \\
\text { rainfall collect- } \\
\text { ed, referred to } \\
\text { watershed as a } \\
\text { whole. }\end{array}$}} & \multirow[b]{2}{*}{$\begin{array}{l}\text { Area of } \\
\text { water- } \\
\text { shed. }\end{array}$} & \multicolumn{2}{|c|}{ Driven-well supply. } \\
\hline & & & & & $\begin{array}{c}\text { Ex- } \\
\text { presse- } \\
\text { as rain- } \\
\text { fall. }\end{array}$ & $\begin{array}{l}\text { Daily per } \\
\text { square } \\
\text { mile. }\end{array}$ \\
\hline 1873-1877. & $\begin{array}{r}\text { Inches. } \\
43.33\end{array}$ & $\begin{array}{r}\text { Per cent. } \\
25.07\end{array}$ & $\begin{array}{r}\text { Inches. } \\
10.86\end{array}$ & $\begin{array}{l}\text { Square } \\
\text { miles. } \\
\quad 52.30\end{array}$ & $\begin{array}{c}\text { Inches. } \\
\text { (b) }\end{array}$ & $\begin{array}{c}\text { Gallons. } \\
(b)\end{array}$ \\
\hline 1878-1882. & 41.58 & $29.60^{1}$ & 12.31 & 55.14 & (b) & (b) \\
\hline $1883-188 \pi$. & 43.30 & 31.60 & 13. 68 & 64.42 & 2.95 & 140,392 \\
\hline $1889-1893 \ldots \ldots$. & 45.05 & 38.43 & 17. 31 & 65.54 & 5.85 & 278,383 \\
\hline $1895-1899 \ldots$ & 43. 14 & 36.32 & 15.67 & 66.44 & 7.76 & 369,581 \\
\hline \multirow{3}{*}{ Period. } & \multicolumn{2}{|c|}{$\begin{array}{l}\text { Other pumped } \\
\text { sonrces of } \\
\text { supply. }\end{array}$} & $\begin{array}{c}\text { Daily } \\
\text { total per } \\
\text { square }\end{array}$ & \multicolumn{3}{|c|}{$\begin{array}{l}\text { water collected as stream } \\
\text { flow, referred to } 50 \text { square } \\
\text { miles of water }\end{array}$} \\
\hline & \multirow{2}{*}{$\begin{array}{c}\text { Ex- } \\
\text { pressed } \\
\text { as rain- } \\
\text { fal]. }\end{array}$} & \multirow{2}{*}{$\begin{array}{l}\text { Daily per } \\
\text { square } \\
\text { mile. }\end{array}$} & $\begin{array}{c}\text { mile } \\
\text { derived } \\
\text { from all }\end{array}$ & \multirow{2}{*}{$\begin{array}{l}\text { Daily per } \\
\text { square } \\
\text { mile. }\end{array}$} & \multicolumn{2}{|c|}{$\begin{array}{l}\text { Expressed as rair- } \\
\text { fall. } \\
\end{array}$} \\
\hline & & & $\begin{array}{l}\text { sources in } \\
\text { the wa- } \\
\text { tershed. }\end{array}$ & & Amourt. & $\begin{array}{l}\text { Propor- } \\
\text { tion of } \\
\text { total. }\end{array}$ \\
\hline $1873-1877$. & $\begin{array}{r}\text { Inches. } \\
0.18\end{array}$ & $\begin{array}{r}\text { Gallons. } \\
8,659\end{array}$ & $\begin{array}{r}\text { Gutlons. } \\
517,206\end{array}$ & $\begin{array}{r}\text { Gallons. } \\
532,034\end{array}$ & $\begin{array}{r}\text { Inches. } \\
11.17\end{array}$ & $\begin{array}{r}\text { Per cent. } \\
25.79\end{array}$ \\
\hline 1878-1882 ... & .99 & 47,063 & 585,978 & 594,310 & 12.48 & 30.02 \\
\hline $1883-1887 \ldots \ldots \ldots$ & 2.30 & 109,041 & 651,506 & 518,071 & 10.88 & 25.13 \\
\hline $1889-1893 \ldots \ldots$. & 4.17 & 198,605 & 824,195 & 455,153 & 9.56 & 21.22 \\
\hline 1895-1899 _.............................. & 2.74 & 130,224 & 745,983 & 327,122 & 6.89 & 15.96 \\
\hline
\end{tabular}

$a$ Merchants' Association of New York, The Water Supply of the City of New York, 1970, p. 186. $b$ Began in 1883 .

While all pumped wells cause a cone of depression, in regions where the ground water moves rapidly and where the demand does not exceed the supply tho recovery is very rapid, as is shown by the figures prepared by W. E. Spear from the records of the Brooklyn water department. $b$

Several points are noteworthy about these diagrams. The water-bearing strata, in the deep and shallow wells, in each case are separated by rather fin m material which may usually be called a clay. There is a distinct flow below the clay layer with a velocity, as shown by Slichter, of 6 feet per day, while that immedistely above

$a$ See discussion in Prof. Paper IT, S. Geol. Survey No. 44, 1906, pp. 78-79.

$b$ Rept. New York City Commission on Additional Water Supply, 1904, appendix 7, PIs. XI, XII. 
the clay layer is but 18 inches. Near the surface the velocity is 3 to 15 feet per day. It is therefore interesting to notice at Agawam, which is essentially a deep-well station, the sympathetic effect of pumping in the lower layer on the water in the upper. There is also an important difference in the depression produced in well No. 11 and well No. 16. This indicates local irregularities in porosity. At Merrick the wells connected to the suction are all shallow but one; the effect of pumping is therefore more marked in the shallow than the deep wells. It is 1 are quite normally greatest in the center well. The recovery after pumping is very rapid in both cases, indicating that the supply is a free one and that the plants have rot overdrawn it.

The records for a 181-foot well at the Queens County Water Company pumping station, near Hewlett, N. I., show regular fluctuations due to pumping (PI. III, p. 18). This well is 3,000 feet from the pumping station and 2,000 feet from the nearest pumped well, and the records showed fluctuations of such a regular rhythmical character that they were at first thought to represent fluctuations due entirely to temperature changes. Further consideration in connection with the record of pumping from the station shows that the fluctuations are almost wholls due to pumping, although there is perhaps a slight temperature effect involved.

The response of the water level in the deeper wells to changes of pressure at the surface, due to rainfall, tidal, barometric, and thermometric flucturtions, suggests that the removal by pumping of the surface ground water over an artesian stratum will, by relief from load, produce sympathetic fluctuations in deep wells where there is absolutely no connection between the water-bearing strata.

\section{EFFECT OF ARTESIAN-WELL DEVELOPMENTS}

The universal experience in artesian basins has been that afte* a time the head decreases. This is due to many causes. When the whole basin is affected, it indicates that the outflow or pumping from the wells exceeds the inflow from the porous strata, and a gradual decrease is to be expected until these factors are balanced. A well or group of wells may be influenced by interference from a single well favorably situated. Thus the drilling of a well in which the outflow is many feet below that of near-by wells quickly affects the head of the higher wells. Very often where but a few wells here and there are affected the decrease in head is to be regarded as wholly due to leakage, either on the outside of the casing or by the failure of the casing through corrosion.

All artesian wells are sooner or later pumped, and the effect of th a pumping is often to lower the head over wide areas. The diminution of the head in the chalk wells in London during the early part of the nineteenth century is well shown by Clutterbuck. $a$

\section{EFFECT OF LARGE CITIES ON THE WATER LTVEL.}

Aside from the general lowering of the water level in cities due to pumpage, another factor tending in the same direction is a decrease of the inflow of ran waters. The mass of buildings, paved streets, and drainage systems absolutely prevent the infiltration of rain water over wide areas. This loss is, however, in part replaced by leakage from the water and sewer systems.

The loading resulting from the placing of large and heavy buildings on small areas will have the same effect as loading due to any natural causes, except that the former is so gradual that in most cases the water has time to escape laterclly. It is conceivable, however, that the loarling may exceed the rate of outflow and a temporary measurable increase in the artesian head be produced, but this is of such slight value as to be of theoretical rather than practical importance. The effect is practically nothing when the building rests on bed rock, as at New York, and reaches its maxi- 
mum at points like New Orleans, Galveston, and other coast towns uncerlain by unconsolidated Tertiary and Quaternary beds. A much more readily measurable effect would be produced by large fires, which in a short time would remc ve a large weight from a limited area. These pressure effects would be noticeable only in wells in which the water is already under artesian head and when the overlying beds have considerable plasticity. They would clearly be greatest in unconsolidated materials and would decrease with the thickness of the strata above the water-bearing layer.

\section{EFFECT PRODUCED BY LOADED FREIGHT TRAINS.}

The sensitiveness of the water in wells to any change in load at the surface is strikingly illustrated by the oscillation produced by slowly moving freight trains at Madison, Wis. This is described by King as follows: $a$

While the self-registering instrument was upon well No. 48, it was observed that there were frequent records of sharp short-period curves shown upon the sheet, which at first were supposed to be the result of accidental jars which the instrument sustained; but the frequency of their occirrence and the fact that they always indicated elevations of the water led to a closer serutiny and their final association with the movement of trains past the well. On the eight-day instrument tr ese fluctuations a re shown as single dashes. but with the one-day form the curve was opeu. The will in which these disturbances occur is situated about 140 feet from the railroad track aud has a depth of 40 feet. It is tubed up with 6-inch iron pipe to the sandstone, 37 feet below the surface, and the water has a mean depth of about 20 feet in it.

The strongest rises in the level of the water are produced by the heavily loaded trains, which move rather slowly. A single engine has never been observed to leave a record. and the rap'dly moving passenger tains produce only a slight movement, or none at all, which is recorded by the instrument. The figure shows the curve to be produced by a rapid but gradual rise of the water, which is followed by only a slightly less rapid fall to the normal level, there being nothing oscillatory in eharacter Indicated by any of the tracings nor observable to the eye when watehing the pen while in motion. The downward movement of the pen usually begins when the engine has passed the well by four or five lengths, and when the pen is watched, it may be seen to start and to descend quite gradually, occupying some seconds in the descent.

This is very similar to the various pressure effects noted above, due to t'dal, barometric, and rainfall loading, and to transmitted fluctuations due to variations in local load produced by temperature changes, except that the time of lateral trensmission is rather shorter, and it is not clear that the water is under artesian head.

\section{FLUCTUATIONS DUE TO. INDETERMINATE CAUSES.}

\section{SMALI FLUCTUATIONS.}

The extreme susceptibility of the water level in wells to pressure changes would lead one to expect many minute fluctuations; and, indeed, all the well curves show a great number of such fluctuations superposed on the larger fluctuations produced by the dominant element at that point. Many are clearly compound waves of very complex character and represent the resultant of many forces. They emphasize the continued state of unrest of the earth's surface. These fluctuations can bo properly studied only with instruments having both a large vertical and time scale, and their elucidation would necessitate corresponding meteorologic instruments of great delicacy.

On the day gages at Hewlett (p. 18) there is a distinct series of minor flıctuations with a well-defined period of about twenty minutes. These greatly resomble the minor oscillations in the tidal curves at many points. $b$

a Bull. U. S. Weather Bureau No. 5, 1892, pp. 67-68.

$b$ See Airy, Sir G. B., On the seiches or nontidal undulations of short period at Malta: Phil. Trans. Royal Soc., 1878, pp. 123-138. Dawson, W. Bell, Notes on secondary undulations recorded by selfregistering t1de gages, Trans. Royal Soc. Canada, sec. 3, 1895, pp. 25-26; Illustrations of remarkable secondary tidal undulations in Nova Scotia, Trans. Royal Soc. Canada, sec. 3, 1899, pp. 23-26. Duff, A. W., Secondary undulations shown by recording tide gages; Trans. Nat. Hist. Soc. New Brunswick, 1897; Am. Jour. Sci., 4th ser., vol. 3, 1897, pp. 406-412, Am. Jour. Sci., 4th ser., vol. 12, 1901, pp. 123-139. Denison, F. Napier, The Great Lakes as a sensitive barometer: Canadian Eng., Oct.-Nov., 1897: Secondary undulations of tide gages, Proc. Can. Inst., n. s., vol. 1, 1897, pp. 28-31; The Great Lakes as a sensitive barometer: Proc. Can. Inst., n. s., vol. 1, 1897, pp. 55-63; The origin of ocean tidal secondary undulations: Proc. Can inst. n. s., vol. 1, 1897, pp. 134-135. 
The secondary oscillations in the tide curve at Swansea, England, have a time interval of fifteen to twenty minutes; at Malta, twenty-one minutes; and at Sydney, twenty-six minutes; while Denison has observed on Lake Huron oscillations with periods of fourteen, eighteen, twenty-two, and forty-five minutes. As no such secondary tidal oscillations have been observed near Long Island, and as the Hewlett well is at such a distance from the coast that it is not affected by tides 4 feet high, these oscillations are clearly not of transmitted ocean origin. Denison's observations led him to the conclusion that many of the secondary oscillation are due to barometric fluctuations, and the occurrence of these fluctuations in wells must be regarded as strong confirmatory evidence of his conclusion.

Besides these fluctuations with a period of twenty minutes, there are several other minor vibrations with smaller amplitudes and periods; one series seems to bave a period of five or six minutes, but is not very sharply defined.

In the wells at Lynbrook ( $\mathrm{p} .23$ ) ninor fluctuations with periods of forty and eighty minutes have been clearly recognized in a mass of still smaller fluctuations.

FLUCTUATIONS AT MILLBURN, N. $\mathbf{Y}$.

Extremely irregular fluctuations with a range of as much as 1 inch were obtained from a well at Millburn, N. Y. (Pl. V, p. 22). These are quite different from any of the other curves obtained and no cause can be assigned for these irregularities. Not the least strange part of the curve is that its general character changes sharply on July 29. (See discussion, pp. 22-23.)

\section{FLUCTUATIONS AT URISINO STATION, NEW SOUTH WALES.}

The fluctuations reported by Professor David $a$ at Urisino Station. between Wanaaring and Milparinka, in the northwest corner of New South Wales, 200 miles from the ocean, are unique. Two subartesian wells, one 1,680 and the other 2,000 feet deep, in which the water rises to within 15 or 20 feet of the surface, show regular rhythmical pulsations with a range of $t$ to 5 feet every two hours. That is, there are here six almost equal "tides" of large size every twenty-four hours. Prof. Charles $\mathrm{S}$. Slichter has suggested the very probable explanation that the fluctuations are due to a sort of periodic geyser phenomena. This is quite competent to produce the fluctuations observed and the high temperature of the water in this hasin lends considerable color to the suggestion.

a David, T. W. E., Notes on artesian water in New South Wales and Queensland: Jour. and Proc. Royal Soc. New South Wales for 1893, vol. 27, pp. 429-430. 


\section{N D E X .}

A.

Agawam, N. Y., pumping at, effect of......

Agram, Hungary, annual fluctuations in well at

Air, fluctuations produced by pressure transmitted through........ 7-8,24,42-43

Airy, G. B., on minor tidal fluctuations at Malta.

Alfriston, England, annual fluctuations in well at.

Almenderes River, Cuba, fluctuations in springs produced by

Aller River, Germany, well fluctuations produced by..................

Ann Arbor, Mich., annual and secular fluctuations in well at.

Annual fluctuations, character and eause of . ......................... 29-34

dates of maximum and minimum, factors affecting ................ 34-37

diagrams showing....... 30, 31, 32 (Pl. IX), 39

Arkansas, well fluctuations produced by Red River in ...................

Artesian well developments, effect of, on water level

Atwell, Joseph, on fluctuating springs in Devonshire

Auchincloss, W. S., on annual and secular fluctuations at Bryn Mawr..... 38, 51

Avalon, N. J., tidal fluctuations in well at. 69

\section{B.}

Baden, Austria, annual fluctuations in well at......................... 41

Bailly, _- on tidal well at Lille, France.. 64,67 Barbour, E. H., on blowing wells in Nebraska.......................

on annual well fluctuations in $\mathrm{Ne}$ braska ............................ 51

Barometric changes, effects of . 7-8, 24-25, 52-54,76

effects of, bibliography of............ 53-54

diagram showing........... 24 (Pl. VI)

Barren Island (Andaman Sea), tidal wells on $\ldots \ldots \ldots \ldots \ldots \ldots \ldots \ldots \ldots, 64,68$

Berlin, Germany, annual fluctuations in well at..........................

annual rainfall and water-level curves at, flgure showing............ 29

Bettes, C. R., aid of..................... 18-19

Bibliography of fluctuations, due to barometric ehanges ............... 53-54

the to ocean tides................... $67-69$

due to rainfall...................... 51-52

due to rivers........................ 62-63

due to temperature.

B

Blowing wells, occurrence aud bibliography of ..................... 53 Bombay, India, tidal wells near........ 64, 67-68 Bowman, Isaiah, well observations by..... 13,16 Braithwaite, Frederick, on tidal-well fluctuations at London.............. 67

Bremen, Germany, annual fluctuations in well at.

annual rainfall and water-level curves at,figure showing ............ 29

Brentwood, N. Y., barograph record at, flgure showing ............ 18 (Pl. III), 22 (Pl. V), 24 (Pl. VI)

observations at.................... 27 . rainfall record at, flgure showing. 18 (Pl. III), 22 (Pl. V), 24 (Pl. VI)

Bronx Park, N. Y., soil temperatures at, observations on............... 57,58

Brooklyn waterworks, effect of pumping at, on stream flow............... 73

Brünn, Austria, annual fluctuations in well at......................... 40

annual rainfall and water-level curves at, flgure showing.............

Bryn Mawr, Pa., annual and secular fluctuations in well at.............40,51

annual rainfall and water-level curves at, flgure showing............ 30

ground-water curves at............... 38

flgures showing................. 30,31

Buckland, Doctor., on London well fluctuations....................... 62

(.).

Cache la Poudre River, Colo., diurnal fluctuations of ...................

rise of ground water along............ Caleves, Switzerland, percolation experiments at..................... 46

Callender, H. L., on soil temperature? ..... 58 Capillarity, effect of, in producing well fluctuations ............. 8,42-43,57

effect of surface changes on.......... 43

Carpenter, L. G., on fluctnations in Cache la Poudre River, Colo......... 59

on rise in ground water along Cache la Poudre River, Colo............

Caterham, England, annual fluctuations in well at.

Caverns, tidal fluctuations transraitted through ................... 62-64

Celle, Germany, well fluctuations produced by Aller River at............ 60-61

Charnock, Charles, lysimeter experiments at Ferrybridge by ............. 
Chelgrove, England, annual fluctuations in well at.

Cheshire, England, annual fluctuations in well at.

Christie, James, on tidal fluctuations in wells .........................

Cities, effect of, on water table........... 74-75

Citizens Water Supply Co., wells of, fluctuations in, plate showing .. 26 (Pl.VII)

wells of, location of, map showing - 26 (Pl. VII) observations on .................. 25-26

Clutterbuck, James, on lysimeters ..... . . . . 48-49

on tidal wells in England . . . . . . . . . 67

on well fluctuations at London..... 51, 62, 74

Cochituate, Lake, Mass., basin of, rainfall and run-off in.................

Colne River, England, well fluctuations at London due to

Color ado, annual fluctuations in infltration gallery in.

annual rainfall and water-level curves in, relations of ................

ground-water fluctuations in .........43,59

Connecticut River, Conn., basin of, rainfall and run-off in ................

Consolidated İce Co., Huntington, N. Y., observations on well of.........

Cretaceous clays, lack of continuity of, on Long Island . . ...............

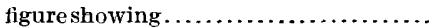

Cretaceous sands, figure showing......... water in ........................ 10,19

Croton River, N. Y., basin of, rainfall and run-off in ..................

Cuba, spring fluctuations produced by Almenderes River in ..............

Cultivation, changes in ground-water level due to .................. $70-71$

Czernowitz, Anstria, annual fluctuations in well at...

D.

Dalton, John, lysimeter experiments of. . . 44-15 Dams, changes in ground-water level due

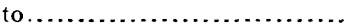

Darwin, G. H., on elastic deformation of the earth ....................6.65-66

David, T. W. E., on well fluctuations in New South Wales..................

Dawson, W. Bell, on secondary tidal fluctuations..............................

Debreczin, Hungary, annual fluctuations in well at....................

Deformation, elastic, of earth, G. H. Ilarwin on.

Deformation, plastic, of earth, well fluctuations due to............... 8,28 ,

$42-43,62-68,65-68,74-75$

Denizet, - on spring fluctuations at Voize, France, due to barometric changes.

Denison, F. Napier, on secondary fluctua-

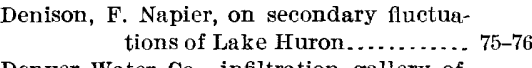

Denver Water Co., infiltration gallery of fluctuations in
Desaguliers, J. T, on tidal fluctuations in England .................. 67

Ilickinson, John, lysimeter of .......... 44-45

Dickinson, John, and Evans, John, percolation experiments of. $32-34,37,45-46,48$ percolation experiments of, diagram showing ....................

Discharge, point of, distance from, relations of fluctuations and ........ $38,49,51$

rate of, fluctuations due to...... 57,61, 63-64

Douglas, $J$. N., on tidal well in Kent, England

67

Douglaston, N. Y., marsh near, description of $\ldots \ldots \ldots \ldots \ldots \ldots \ldots \ldots \ldots . \ldots \ldots$

marsh near, map showing...... 26 (Pl. VII)

mud volcanves near. .............. 25-6

wells at, description of ............. 25

fluctuations in ............... 26 flgure showing........ 28 (Pl. VIII) lag in ................... 25,66 location of, map showing .... 26 (Pl. VII) observations on . ........... 10,25-26,66 errors in . . . . . . . . . .

Drainage, changes in water table due to... 70

Dubois, H. J., well record by ............. 12

Duff, A. W., on secondary tidal fluctuations in New Brunswick............ 75

\section{E.}

Earthquakes, changes in vater table due

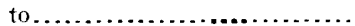

East Rockaway Inlet, tide curves at, figure showing .............. 20 (P1.IV)

Eastdean, England, annual fluctuations in well at.................... 41

Ebermeyer, Dr. E., on forest litter........ 71

on lysimeters ..................... 48

Elbe River, Germany, artesian wells in bed of $\ldots \ldots \ldots \ldots \ldots \ldots \ldots \ldots \ldots . \ldots 2$

Emery, F. E., on annual fluctuations in well at Genera, N. I ............. 51

England, annual fluctuations in wells in . . 41, 51 barometric fluctuations in springs and wells in ................... $53-54$ blowing well in ...................... 53 decrease of head in artesian wells in ... 74 fluctuations due to rivens in ......... 62 percolation experiments in...... 32-34, 41-47 tidal fluctuations in $\mathrm{we}^{1 / \mathrm{s}}$ in ...... 64, 67-6? Erosion, changes in water table due to..... 69 Europe, annual and secular fluctuations in wells in ..... $44-35,3 \&, 40-41,51,61-62$ annual rainfall and water-level curves in, flgures showing. 29, 32 (P1. IX), 62 Evans and Dickinson. See Dickinson and Evans.

Evaporation, loss by ................... Evaporation and rainfall, fluctuations due to. ..................... $29-42$ F.

Farrley, T., on blowing well in England... 53 Fenhurst, N. Y. Se' Hewlett, N. I.

51 Fires, effect of, on water level.

\section{1}

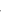

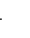


Flood flows, contribution by ground water

\section{Page.}

to...................... $8,42,49$

definition of .

effect of showers on .................. 42 See also Stream flow.

Floral Park, N. Y., observations at........ $\quad 27$ rainfall records at, flgures showing... 18 (Pl. III), 22 (Pl. V), 24 (Pl. VI)

thermograph records at, flgures show-

ing.. 18 (Pl. III), 22 (Pl. V), 24 (Pl. VI)

Fluctuations in ground-water level, amount of .................... $7,38-41,51$

causes of . ...................... $7,28-76$

classification of.

28

See also Annual fluctuations; Artesian wells; Bibliography; Capillarity; Cities; Dams; Deformation; Forests; Geysers; Geologic changes; Irrigation; Pumping; Rainfall; Secular fluctuations; Showers; Soil; Streams; Tides.

Forest, effect of, on ground-water level.... Fortier, Samuel, on underfiow ............. France, barometric fluctuations in springs in ............................

forests in, effect of, on ground-water level..........................

percolation experiments in............. tidal fiuctuations in wells in ..... $62,64,67-69$

Frankfurt, Germany, annual fluctuations in well at...

annugl rainfall and water-level curves in wells at, Hgures showing.....

Freund, Adolf, report of, on Vienna waterworks

Frazer, Persillor, on tidal well at Seagirt, N. J.........................

Friez gage, description of

Fuller, M. L., on spring fluctuations in Cuba, due to river changes.....

Fulton, Ark., fluctuations due to stream flow in well in.................

$$
\text { G. }
$$

Gages, direct-reading, description of ...... 10-11 observations with ................... 10-17 self-recording, descrintion of .......... 17-18 observations with $\ldots \ldots \ldots \ldots \ldots \ldots \ldots . . \ldots \ldots$ 18 -26

Galleries, infiltration, changes in water table due to................ $72-73$

Gasparin, Doctor, lysimeter experiments of.

Genesee River, N. Y., basin of, rainfall and run-off in . ...................

Geneva, N. Y., annual fluctuations in well at.......................... 40,51

annual rainfall and water-level curves in well at, figure showing ......

Geneva, switzerland, percolation experiments at......................

Geologic causes, changes in ground-water level due to................. 69-70

Geological Survey, U. S., observations by ... 10-27 Georgia, tidal fluctuations in wells in..... 68 Gerhardt, P., on annual fluctuations....... 51 on fluctuations due to stream flow...... 63
Germany, annual and secular fluctuations

in wells in.................. 40

percolation experiments in ........... 46-47

well fuctuations due to streams in .... 60-62 Geysers, well fluctuations due to......... 70,76 Gilbert and Lawes. See Lawes and Gilbert. Görlitz, Germany, percolation experim ${ }^{\circ}$ ts at............................

Gough, John, on barometric fructuatior a in Yorkshire wells............... Graz, Austria, anuual fluctuations in well at........................... Greaves, Charles, percoktion experiments of ..................... $s 2-33,46,49$

Green, H., gages of, description of ....... 18 Ground water, definition of .............. 42 topography and, relations of ....... $39,69-70$ See also Bibliography; Capillarity; Cities; Dams; Deformation; Forests; Flood flow; Geysers; Geologic changes; Human agencies; Irrigation; Pumping; Rainfall; Showers; Streams; Stream flow; Temperatures; Tides.

Ground-water curves, relation of rainfall curves and, figures showing....

(Pl. III), 22 (Pl. V), 24 (Pl.VI), 29, 30, 31, 32 (Pl. IX), 36, 39

Ground-water divide, distance from, effect of, on fluctuations............. 38, 49

figure showing.....................

H.

Hallan de Roucroy, on spring fuctuations in Iceland ...................

tidal fluctuations at Lille, France... $\quad 68$

Hiarris, G. D., on blowing wells in Louisiana ........................

on relations of Mississippi River to well fluctuations ..................

Headdon, W. P., on effect of showers on ground water............... 43,51

Hemel Hempstead, England, annual percolation and rainfall curves at, flgure showing.............. 32

percolation experiments at.... $32-34,45-46,48$ Henry, E., and Tolsky, A., On relations of forests and ground water...... 71

Hess, - - on fluctuations due to steam flow .........................

Hertfordshire, England, annual fluctuations in well in.................... 41

Hewlett, N. Y., wells at, description of.... 18-19 wells at, location of, maps showin $5 . . .99$

(Pl. I) , 16 (Pl. II)

observations on ............ 18-19,75-76

pumping of, effect of............. 74 effect of, figure showing.. 18 (P1. III)

tidal fiuctuation in, figure shoving. 18

(Pl. III)

Hicksville, N. Y., annual fluctuations in wells at.......................

Hudson River, N. Y., basin of, rainfall and run-off in....................

Human agencies, ground-water flustuations due to ................ 70-75 
Humus, absorptive capacity of

Page.

Huntington, N. Y., wells at, description of . 10-13 wells at, location of ................. 11 location of, figure showing........ 11 observations on .................. 10-13 tidal fluctuation in, figure showing. $\quad 12$ lag in..................... 10,66

Huntington Light and Power Co., well of, location of, figure showing ..... 11

well of, observations on ............. 10-13 record of

Huron, Lake, secondary tidal oscillations on .

Hutton, F. W., on tidal fluctuations at New Brighton, Englaud

I.

Iceland, springs in, tidal fluctuations of ... 64,68 Infiltration from rivers, fluctuations due to. $60-61$ Infiltration galleries, changes in water table

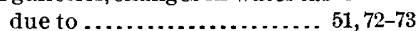

Inglis, Gavin, on tidal fuctuations in springs in Yorkshire.

Innsbrück, Austria, annual fluctuations in well at.

Irrigation, changes in water table due to ..

$$
\text { J. }
$$

Jaegle, W. C., well record by

Japan, barometric fiuctuations in well in..

Jevington, England, annual fiuctuations in well at

Josephstadt, Austria, annual fiuctuations in well at

K.

King, F. H., citations of . . 42-43, 51-56, 63, 68-69,75 evaporation experiments by............ 49

Klagenfurt, Austria, annual flucturtions in well at

Knightly, T. E., on barometric fuctuations in Derbyshire wells ............

Krakau, Austria, annual fluctuations in well at.

L.

Lag in well fuctuations ................ 13, $17,19,21-22,24,34-36,60-62,64-66$

Lake level, changes in, effect of, on water table ..................... 63,69

Lane, A. C., on blowing well in Michigan..

Lansing, Mich., annual fuctuations in well at................................

annual rainfall and water-level curves at, figure showing

Latham, Baldwin, on barometric fuetuations in springs in England ....

Lawes, John, and Gilbert, J. H., percolation experiments of ....... 32-34,37,47-48

percolation experiments of, nigure showing ...........................

Leakage from rivers, effect of, on water level........................ 61-63

Leitha River, Austria, effect of, on ground water.

$35,61-62$
Page.

Lille, France, tidal wells at......... 62,64,67-69

Lincoln, Nebr., soil tempers.tures at, observations on ......................

Liverpool, England, barometric and tidal fiuctụations in well near.... 54,68-69

Liznar, Joseph, on periodic fluctuations in wells

52

London, England, annuål and secular fluctuations in wells at. ...........41,51

barometric fluctuations in wells at.... 53

diminution of artesian head at........ $\quad 74$

fiuctuations due to riv rs at........... 62

percolation experiments near.......... 46

tidal fuctuations in wolls at .......... 67

Long Beach, N. Y., well at, description of ............................ 19-20 well at, location of, maps showing. . 9(Pl.I), 16 (Pl. II)

observations on ................ 10,19-2) errors in................... 18

record of $\ldots . . . \ldots \ldots \ldots \ldots \ldots \ldots . . .20$

tidal fiuctuations in........ 18, 21-22, 66 figure showing.......... 20 (Pl.IV) lag in ....................... 19,66

Long Island, blowing wel's on........... 53 ground water on, sourse of ........... 10 hydrologic conditions on............. 9-10 figure showing................. 9 similarity of, to those at Wiener Neustadt .................... 35

irrigation on........................ 72 map of southern part of .......... 16 (Pl. II) map of western end of ............. 9 (Pl.I) observations on .................... 10-27 ponds on, effect of.................. 72 pumping on, effect of............... 73 rainfall curves on, figures showing. 18(Pl. III), 22 (Pl.V), 24 (Pl.VI) , 30, 36, 37, 39 section of. secular fiuctuations on ............... 37-38 south side of, rainfall and run-off on... 50 stream fiow on ..................... 10,50 topography of $\ldots \ldots \ldots \ldots \ldots \ldots \ldots \ldots \ldots . \quad 9$ underfiow on...................... 73-74 wells on, fiuctuations it ............. 10-27, $35,37-38,40,42-44,49,52-53,57-59$, $62,66,74-76$.

fuctuations in, fig ires showing.... 12, 16, 18 (Pl. III), 20 (Pl. IV), 22 (Pl. V), 24 (Pl.VI), 26 (Pl.VII), 28 (Pl. VIII), $30,36,39$. observations on............... 9-27

Louisiana, blowing wells in.............. 53 fiuctuations of wells in, due to Mississippi River

Lueger, Otto, on annual fiuctuations in wells

on barometric fluctuations in wells and springs ......................

Lynbrook, N. Y., wells at, description of ... wells at, fluctuations in............ 22, $42-43,49,52,57-59,62,76$ location of, map showing...... 9 (Pl. I), 16 (Pl. II) observations on............. 23-25,57-59 record of $\ldots \ldots \ldots \ldots \ldots \ldots \ldots \ldots ., 23$

\begin{tabular}{l}
7 \\
7 \\
7 \\
7 \\
\hline
\end{tabular}


Page.

Lysimeters, descriptions of $32,44-47$ objections to $44,48-49$ observations with $\ldots \ldots \ldots \ldots \ldots \ldots .32,34,44-49$ results of, figure showing.......... 32

M.

MeCallie, S. W., on tidal well fluctuations in Georgia ....................

McDóngal, D. T , on soil temperatures

Madison, Wis., temperature and well fluctuations at ................. 54-57

well at, fiuctuations in, due to showers. fluctuations in, figure showing..... record of .........................

Maghull, England, tidal and barometric fluctuations in well at...... 54,68-69

Malabar coast, tidal wells on. 64,67

Mallet, F. R., on tidal fluctuations in wells

in Wales.....................

Malta, secondary tidal oscillations at......

Manchester, England, percolation experiments at......................

Mandan, H. G., on tidal wells............. 64, 68

Map of Douglaston and vicinity.......... $\quad 26$

of Oyster Bay and vicinity ............ 13,14

of property of Huntington Light and Power Company and vicinity ..

of southern Long Island ......... 16 (PI. II)

of western Long Island ............ 9 (Pl. I)

Maurice, —, lysimeter experiments of.... $\quad 45$

Mead, Elwood, gage of, description of ..... 18

Merrick, N. Y., pumping at, effect of...... 74

Mesilla Park, N. Mex., underflow at....... 13,62

Meyer, Cord, aid of ................... $\quad 25$

Meyer, J. E., aid of..................... 25

Michigan, annual and secular fluctations in wells in ....................

blowing well in

rainfall and water-level curves in, flgures showing ..................

water level in, observations on.........

Mill ponds, effect of, on ground-water level.

Millburn, N. Y., well at, fluctuations in.... 22 -

well at, fluctuations in, figures show$23,38,40,76$ ing................. 22 (Pl. V) 30,39 location of, map showing....... 9 (Pl. I),

16 (P1. II $)$

observations on .............. 10,22-23

rainfall and water-level curves in,

$\checkmark$ figures showing . 30,39

Milne, John, on barometric fiuctuations in well in Japan ..................

Moore, H.C., on tidal fiuctuations in wells. Mud volcanoes, location of, near Douglaston, map showing ....... 26 (Pl, VII)

occurrence of, near Douglaston ........ 25-26

Munich, Germany, annual fluctuations in well at.......................

annual rainfall and water-level curves in well at, figure showing......

percolation experiments at ............

Muskingum River, Ohio, basin of, rainfall and run॰off in

IRR 155-06-6

$\mathrm{N}$

New York City commission on additional water supply, observation $\checkmark$ of, on Long Island ................

observations of, results of, flgure s'owing................... 18 (PI. III), 22 (PI. IV), 26 ( $\mathrm{P}^{\mathrm{r}}$. VII), 36

Newark, N. J., residual-mass curves of rainfall at $\ldots \ldots \ldots \ldots \ldots \ldots \ldots \ldots . \quad 37$

Newell, F. H., aid of .................. 17-18 North Allerton, England, blowing well at. 53

o.

Oliver, William, on minor periodic fluctuations of well in England.........

Ototsky,, ., on forests and ground water... Oyster Bay, N. Y., sections at, figures show-

Muskingum River, Ohio-Continued.

Page.

Nashua River, Mass., basin of, rainfall and run-off in.

50

51

53

57

50

New Jersey, annual fluctuations in wellsin. $\quad 52$

1 artesian wells in, fiuctuations in ....... 69 $66-69$

New York, annual fluctuations in well at Geneva.....................

51 $57-58$

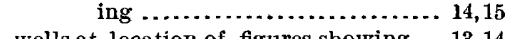

wells at, location of, figures showing... 13,14 observations on . . . . . . . . . . 15-17, 66 tidal fluctuations in .............. 17 flgure showing .............. 17

\section{P.}

Paleozoic rocks, occurrence of .......... $\quad 10$

occurrence of, figure showing ......... 9

Pearson, w., on tidal-well fluctuations in Engiand.................... 68

Pennsylvania, annual fluctuations in well in ........................... 51

Pensacola, Fla., fluctuations in wells at.... 67-69 Pequanock River, Conn., basin of, rainfall and run-off in ................ 50

Percolation, amount of, estimation of. $\hat{\imath}^{2}-37,44-51$ rainfall and, relations of, figure sl owing $\ldots \ldots \ldots \ldots \ldots \ldots \ldots \ldots \ldots, \quad 32$ stream flow and, relations of .......... 49-50 Perim Island (Red Sea), tidal wells on .... $64,68^{-}$ Perkiomen Creek, Pa., basin of, rainfall and run-off in ...................... 50

50 Philadelphia, Pa., rainfall curve at ....... 31,37

(1)

(1)


Plastic deformation. See Deformation, plastic.

Pleistocene gravels, of Long Island, occurrence of .

Pliny the Elder, on barometric fluctuations in wells in Italy ...............

on temperature fluctuations in wells in Italy.

on tidal fluctuations in wells in Italy :-

Pliny the Younger, on barometric fluctuations in wells in Italy .........

Point of discharge. See Discharge.

Poisenille, - , on temperat ure and viscosity .

Prag, Hungary, annual fluctuations in well at.............................

Pressure, transmitted, fluctuations produced by ................... $7-8$,

$24,28,42-43,62-63,65-68,74-75$

Pumping, effect of, on ground water ..... 52,73 effect of, on ground water, plate showing .................... 18 (Pl. III)

on stream flow ................. 73

Purdue University, lysimeter experiments at...........................

Q.

Queens County Water Co., wells of... 18-19, 23-25 wells of, fluctuations in, figures showing . 18 (Pl. III), 24 (Pl. VI)

\section{R.}

Railway trains, effect of, on water table ... 42, 75 Rainfall, contribution to ground water by. 44-51 effect of, on ground water....... 7,24, 29-52 excess of, effect of .................. 37-38

effect of, flgure showing ........34,36, 37 figures showing ............. 18 (PI. III), $22(\mathrm{Pl}, \mathrm{V}), 24$ (PI. VI), $29,30,31,32,36,37,39$

fluctuations due to ............. 7,24, 29-52

bibliography of................. 51-52

percolation of, amount of ............ 38

effect of ........................ 44

observations on .................. 32-34 residual-mass curves of, figures show-

ing $\ldots \ldots \ldots \ldots \ldots \ldots \ldots \ldots 32,36,37,39$

statistics of ................ 40-41,45-47,50 stream flow and, relations of. $7-8,10,24,49-51$ See also Showers.

Rainfall curves, relation of ground-water curves and, figures showing.. 18 (Pl. III), 22 (Pl. V), 24 (P1. VI) $, 29,30,31,32,36,39$ Rathbun, F. D., work of........... 18 (PI. III),
20 (Pl. IV), 22 (Pl. V)

Red River, Ark., fluctuations in wells along Residual mass rainfall curves, figures showing $\ldots \ldots \ldots \ldots \ldots \ldots \ldots \ldots . \ldots \ldots \ldots, 32,37,39$

Riegler, - , on forest litter ..............

Rio Grande, relation between water table and bed of....................

Risler, _ - lysimeter experiments by ..... Rivers. See Streams.

Riviere, - - on tidal fluctuations in spring at Givre .....................

Robert, E., on tidal fluctuations in Iceland springs
Sach, B., on artesian well $\div$ in Elbe River.

Salt water, expulsion of, from formations of Long Island ...............

infiltration of, prevention of........... Salzburg, Austria, annual inctuations at .. annual rainfall and water-level curves at, flgure showirg .............

observations at......................

Saturation, zone of, depth of soil above, effect of, on ground-water fluctuations .................... 34-37

Schrieber, Adolf, well of, ot servations on.. 22-23 Seagirt, N. J., tidal wells at.............. 64,68 Secular fluctuations, amoun of.......... $\quad 40$

diagrams showing .................. 32, 39

occurrence of ........................ 37-38

range of .......................... 40

Sedimentation, changes in water table due to ......................... 63,69

Seepage, effects of ................... $61-63$ Shelford, W., on tidal fluetuations in Lincolnshire wells .............67-68 Sherlock, Kans., fluctuation dne to temperature change at............... 59 ground-water movement, at...........60-61 Showers, effect of, on wells....... 35-37, 42-44, 51 effect of, on wells, diagramsshowing... 24 (Pl. VI) $, 36,39$

Sidney, secondary tidal oseillations at..... 76 Silt iu rivers, effect of, on ground water... 61, 70 Sinclair, W. F., on tidal fluctuationsin Bombay wells ................... 68 Siphons, natural, hypothetizal, question of. 53,70 slichter, C. S., aid of.................... 17-18 on fluctuations in ground water due to stream flow ................. 62-63 on ground-water movementsin Kansas. $\quad 60$ on rise of ground water in Kansas...... 71 on underflow on Long I 1 land........... 73 on well fluctuations ................. 54 on well fluctuations in Naw SouthWales. - 76 Soil, air in, pressure transmitted to ground water by ............... 7-8, 24, 42-43 depth of, effect of, on ground-water fluctuations..................... 34-37 temperature of, relatiors of well fluctuations and ................... 54-59

Solution, changes in water table due to... $\cdot 69$ soyka, Isidor, figures by .................. 29 on annual fluctuations ............... 52 on fluctuations due to rivers........... 63

Spear, W. E., figures by .................36, 37 observations by .................. 27, 35, 50. on flood flow......................... 10 
Spear, W. E.-Continued.

on fluctuations on Long Island due to pumping.

Springs, intermitting, occurrence of .

Storer, John, on tidal fiuctuations in wells in Yorkshire.

Stream fiow, effect of pumping on......... 73 estimation of percolation from.......... 49-50 ground water and, relations of ..... $7-8,49-50$ rainfall and, relations of........ $7-8,24,49-50$ See also Flood flow.

Streams, fluctuations in wells due to...... 59-63 fluctuations in wellsdue to, bibliography of ......................... $62-63$

infltration from .................... $61-62$

silt in, effect of ..................... 61-62

fluctuations in springs due to....... 63

plastic deformation due to.......... 62

Streams, silted, relation of ground-water

level and ..................6.61-62

Subsurface dams, effect of, on ground-water level.

Sudbury River, Mass., basin of, rainfall and run-off in ......................

Sussex, England, annual fluctuations in wells in.

Swansea, secondary tidal oscillations at ... Swezey, G. D., on soil temperatures in $\mathrm{Ne}$ braska...

72

50

41.

76

Switzerland, percolation experiments in.. 45-46 Szegedin, Hungary, annual fluctuations in well at

T.

Temperáture changes, depth and, relation of .......................... 57-58

effect of, on wellfluctuations. $8,24-25,51,54-59$ bibliography of.................. 59

figure showing ................. 58

nontransmission of, figure showing. $\quad 56$

Tharoud, Germany, percolation experiments at.......................

Thomassey, Raymond, on seepage from Mississippi River ...............

Tides, effect of, on still box ............... effect of, on well fluctuations. . 8, 10-26, 63-69 bibliography of................, 67-69 observations on ................. 10-26

Todd, J. E., on annual fluctuations....... 52 on barometric fluetuations............ 54 on fiuctuations in South Dakota wells due to Missouri River..........

Tolsky and Henry. See Henry and Tolsky. Topography, relations of ground-watertable and .........................

Trautwine, J. C., jr., on tidal fluctuations in wells.

Tribus, L. L., on fiuctuations in New Jersey wells due to rainfall.............

on tidal fluctuations in Florida ........ 68-69

Trieste, Austria, annual fluctuations in wells at

Tybee Island, Georgia, tıdal fuctuations in well at
U.

Page.

Underflow, loss by ........................

United States, rainfall and ground-water curves in, figures showing...... 30,31

Urusino station, New South Wales, well

fiuctuations at.................. $\quad 76$

V.

Valley Stream, N. Y., observations or well fluctuation at.................

See also Lynbrook and Hewlett.

Van Nostrand, D. L., on depth of mud near Douglaston...

Veatch, A. C., on Arkansas and Louisiana fiuctuations due to strearss....

on Long Island blowing wells...........

Vento, Cuba, spring fluctuations at, due to Almenderes River..............

Ventor, M. J., on tidal fiuctuations in well at.....

Vermeule, c. C., on tidal fluctuations in wells in New Jersey .............

Von Mollendorf, G., lysimeter experiments by $\ldots \ldots \ldots \ldots \ldots \ldots \ldots \ldots \ldots$.

W.

Wales, tidal fuctuations in ............... Ward, L. B., on pumping on Long Isl und.. Wells. See Annual fiuctuations; Artesian wells; Bibliography; Cavillarity; Cities; Dams; 'Deformation; Forests; Geysers; Geologic changes; Irrigation; Pumping; Rainfall: Secular fiuctustions; Showers; Soll; Streams; Tides.

Wells, blowing, occurrence and bibliography of ....................... 53

Wells, sea-coast, peculiarities of ........64,67-68 Whitney, F. L., work of ........... 18 (Pl. III), 22 (Pl. V) , 24 (Pl. VI), 26, 28 (PI. VIII)

Wiener Neustadt, Austria, water level at, compared with that on Long Island ..................... 35

water level at, fluctuations of ....... 38, 41,51 fluctuations of, flgure showin $\gamma . . .3 \quad 32$,

(Pl. IX)

observations on................ 34-35, 38

percolation and, relations of ....... 44

Wisconsin, barometric fluctuations ir wells in .......................... 53-57

Woldrich, J. N., on effeet of rainfall on ground water............... 29, 52

Wolff, H. C., observations by ............. 59

Wollny, E., lysimeter experiments by..... 47

on forest litter...................... 71

Wood, J. G., on tidal fluctuations ......... 69

Woolman, Lewis, on tidal fluctuations in New Jersey wells..............

69

Y.

Yorkshire, England, percolation experiments in ......................

Young, G. and J. Bird, on tudal flucteations in Yorkshire wells.

73

3

)

5





\title{
CLASSIFICATION OF THE PUBLICATIONS OF THE UNITED STATES GE0 ${ }^{\top}$.MGICAL SURVEY.
}

\author{
[Water-Supply Paper No. 155.]
}

The serial publications of the United States Geological Survey consist of (1) Annual Reports, (2) Monographs, (3) Professional Papers, (4) Bulletins, (5) Mineral Resources, (6) Water-Supply and Irrigation Papers, (7) Topographic Atlas of United States-folios and separate sheets thereof, (8) Geologic Atlas of the United Statesfolios thereof. The classes numbered 2, 7, and 8 are sold at cost of publication; the others are distributed free. A circular giving complete lists may be had on application.

Most of the above publications may be obtained or consulted in the following ways:

1. A limited number are delivered to the Director of the Survey, from whon they may be obtained, free of charge (except classes 2,7 , and 8), on application.

2. A certain number are delivered to Senators and Representatives in Cororress for distribution.

3. Other copies are deposited with the Superintendent of Documents, Washington, D. C., from whom they may be had at prices slightly above cost.

4. Copies of all Government publications are furnished to the principal public libraries in the large cities throughout the United States, where they may be consulted by those interested.

The Professional Papers, Bulletins, and Water-Supply Papers treat of a variety of subjects, and the total number issued is large. They have therefore been classified into the following series: A, Economic geology; B, Descriptive geology; C, Systematic geology and paleontology; D, Petrography and mineralogy; E, Chemistry and physics; F, Geography; G, Miscellaneous; H, Forestry; I, Irrigation; J, Water storage; K, Pumping water; L, Quality of water; M, General hydrographic investigations; N, Water power; O, Underground waters; $\mathrm{P}$, Hydrographic progress reports. This paper is the fifty-second in Series $\mathrm{O}$, the complete list of which follows ( $\mathrm{PP}=\mathrm{Pro}$ fessional Paper; $B=$ Bulletin; WS=Water-Supply Paper):

\section{SERIES O, UNDERGROUND WATERS.}

WS 4. A reconnaissance in southeastern Washington, by I. C. Russell. 1897.96 pp., 7 pli, (Out of stock.)

Ws 6. Underground waters of southwestern Kansas, by Erasmus Haworth. 1897. 65 pp., 12 pls. (Out of stock.)

WS 7. Seepage waters of northern Utah, by Samuel Fortier. 1897.50 pp., 3 pls. (Out of stock.)

WS 12. Underground waters of southeastern Nebraska, by N. H. Darton. 1898. 56 pp., 21 pls. (Out of stock.)

WS 21. Wells of northern Indiana, by Frank Leverett. 1899. 82 pp., 2 pls. (Out of stock.)

WS 26. Wells of southern Indiana (continuation of No. 21), by Frank Leverett. 1899. 64 pp. (Out of stock.)

WS 30. Water resources of the lower peninsula of Michigan, by A. C. Lane. 1899.97 pp., 7 pls. (Out of stock.)

WS 31. Lower Michigan mineral waters, by A. C. Lane. $1899.97 \mathrm{pp}, 4$ pls. (Out of stock.)

WS 34. Geology and water resources of a portion of southeastern South Dakota, by J. E. Todd. 1900. 34 pp., 19 pls.

WS 53. Geology and water resources of Nez Perces County, Idaho, Pt. I, by I. C. Russell. 1901. 86 pp., 10 pls. (Out of stock.)

WS 54. Geology and water resources of Nez Perces County, Idaho, Pt. II, by I. C. Rusvell. 1901. 87-141 pp. (Out of stock.) 
WS 55. Geology and water resources of a portion of Yakima County, Wash., by G. O. Smith. 1901. 68 pp., 7 pls. (Out of stock.)

WS 57. Preliminary list of deep borings in the United States, Pt. I, by N. H. Darton. 1902. $60 \mathrm{pp}$. (Out of stock.)

WS 59. Development and application of water in southern California, Pt. I, by J. B. Lippincott. 1902. 95 pp., 11 pls. (Out of stock.)

WS 60. Development and application of water in southern California, Pt, II, by J. B. Lippincott. 1902. $96-140 \mathrm{pp}$. (Out of stock.)

WS 61. Preliminary list of deep borings in the United States, Pt. II, by N. H. Darton. 1902. $67 \mathrm{pp.}$ (Out of stock.)

W's 67. The motions of underground waters, by C. S. Slichter. 1902. 106 pp., 8 pls. (Out of stock.)

B 199. Geology and water resources of the Snake River Plains of Idaho, by I. C. Russell. 1902.192 pp., 25 pls.

WS 77. Water resources of Molokai, Hawaiian Islands, by Waldemar Lindgre`. $1908.62 \mathrm{pp.,} 4$ pls.

WS 78. Preliminary report on artesian basin in southwestern Idaho and southeastern Oregon, by I. C. Russell. 1903.53 pp., 2 pls.

PP 17. Preliminary report on the geology and water resources of Nebraska west of the one hundred and third meridian, by N. H. Darton. $1903.69 \mathrm{pp} ., 43 \mathrm{pls}$.

WS 90. Geology and water resources of a part of the lower James River Valley, South Dakota, by J. E. Todd and C. M. Hall. 1904. 47 pp., 23 pls.

Ws 101. Underground waters of southern Louisiana, by G. D. Harris, with discessions of their uses for water supplies and for rice irrigation, by M. L. Fuller. $1904.98 \mathrm{pp}, 11 \mathrm{pls}$.

WS 102. Contributions to the hydrology of eastern United States, 1903, by M. L. Fuller. 1904. 522 pp.

WS 104. Underground waters of Gila Valley, Arizona, by W. T. Lee. 1904.71 pp., 5 pls.

WS 110. Contributions to the hydrology of eastern United States, 1904; M. I. Fuller, geologist in .charge. 1904. 211 pp., 5 pls.

PP 32. Geology and underground water resources of the central Great Plains, by N. H. Darton. 1904. 433 pp., 72 pls. (Out of stock.)

Ws 111. Preliminary report on underground waters of Washington, by Henry Landes. 1904.85 pp., $1 \mathrm{pl}$.

Ws 112. Underfow tests in the drainage basin of Los Angeles River, by Homer Hamlin. 1904. 55 pp., 7 pls.

ws 114. Underground waters of eastern United States; M. L. Fuller, geologist in charge. 1904. 285 pp., 18 pls.

WS 118. Geology and water resources of east-central Washington, by F. C. Calkins. 1905. 96 pp., 4 pls.

B 252. Preliminary report on the geology and water resources of central Oregon, by I. C. Russell. 1905. 138 pp., 24 pls.

Ws 120. Bibliographic review and index of papers relating to underground we.ters, published by the United States Geological Survey, 1879-1904, by M. L. Fuller. 1905. 128 pp.

WS 122. Relation of the law to underground waters, by D. W. Johnson. 1905. $55 \mathrm{pp}$.

Ws 123. Geology and underground water conditions of the Jornada del Muerto, New Mexico, by C. R. Keyes. 1905. 42 pp., 9 pls.

WS 136. Underground waters of the Salt River Valley, by W. T. Lee. $1905 . \quad 19.1 \mathrm{pp} ., 24$ pls.

B 264. Record of deep-well drilling for 1904, by M. L. Fuller, E. F. Lines, and A. C. Veatch. 1905. $106 \mathrm{pp}$.

PP 44. Underground water resources of Long Island, New York, by A. C. Veatch and otlers, 1905. 394 pp., 34 pls.

Ws 137. Development of underground waters in the eastern coastal plain region of southern California, by W. C. Mendenhall. 1905. 140 pp., 7 pls. -

WS 138. Development of underground waters in the central coastal plain region of southern California, by w. C. Mendenhall. $1905.162 \mathrm{pp} ., 5 \mathrm{pls}$.

Ws 139. Development of underground waters in the western coastal plain region of southern California, by W. C. Mendenhall. 1905. 105 pp., 7 pls.

WS 140. Field measurements of the rate of movement of underground waters, by C. S. slichter. 1905. $122 \mathrm{pp}, 15 \mathrm{pls}$.

Ws 141. Observations on the ground waters of Rio Grande Valley, by C. S. S :chter. 1905.83 pp., 5 pls.

WS 142. Hydrology of San Bernardino Valley, California, by W. C. Mendenhall, 1905. 121 pp., 13 pls. Ws 145. Contributions to the hydrology of eastern United States; M. L. Fuller, gẹologist in charge. 1905. 220 pp., 6 pls.

Ws 148. Geology and water resources of Oklahoma, by C. N. Gould. 1905.178 pp., 22 pls.

WS 149. Preliminary list of deep borings in the United States, second edition, with additions, by N. H. Darton. 1905. 175 pp.

PP 46. Geology and underground water resources of northern Louisiana and southern Arkansas, by A. C. Veatch. 1906.

WS 153. The underflow in Arkansas Valley in western Kansas, by C. S. Slichter. $1966.90 \mathrm{pp.}$ 
WS 154, The geology and water resources of the eastern portion of the Panhandle of Texas, by C. N. Gould. 1906. 61 pp., 15 pls. .

WS 155. Fluctuations of the water level in wells, with special reference to Long Island, New York, by A. C. Veatch. 1906. $83 \mathrm{pp}$.

The following papers also relate to this subject: Underground waters of Arkansas Valley in eastern Colorado, by G. K. Gilbert, in Seventeenth Annual, Pt. II; Preliminary report on artesian waters of a portion of the Dakotas, by N. H. Darton, in Seventeenth Annual, Pt. II; Water resources of Illinois, by Frank Leverett, in Seventeenth Annual, Pt. II; Water resources of Indiana and Ohio, by Frank Leverett, in Eighteenth Annual, Pt. IV; New developments in well boring and irrigation in eastern South Dakota, by N. H. Darton, in Eighteenth Annual, Pt. IV; Rock waters of Ohio, by Edward Orton, in Nineteenth Annual, Pt. IV; Artesian-well prospects in the Atlantic coastal plain region, by N. H. Darton, Bulletin No. 138 .

Correspondence should be addressed to

The Director,

United Stateas Geological Surv.sy, Washingtor, D. C.

JUNE, 1906. 